Sin

$\sin _{5}, \frac{2 \pi}{3}$

Low-Flow Characteristics of Streams in 22 3 the Upper Wisconsin River Basin, Wisconsin

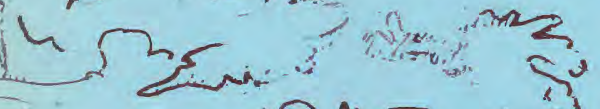

(2),

2

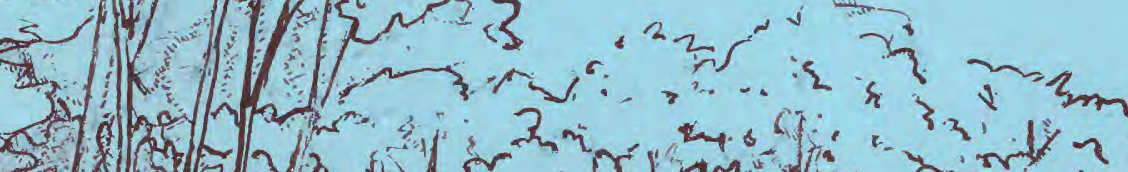

a)

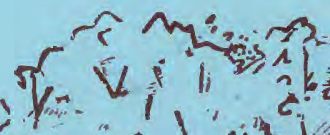

Ar ${ }^{2}$
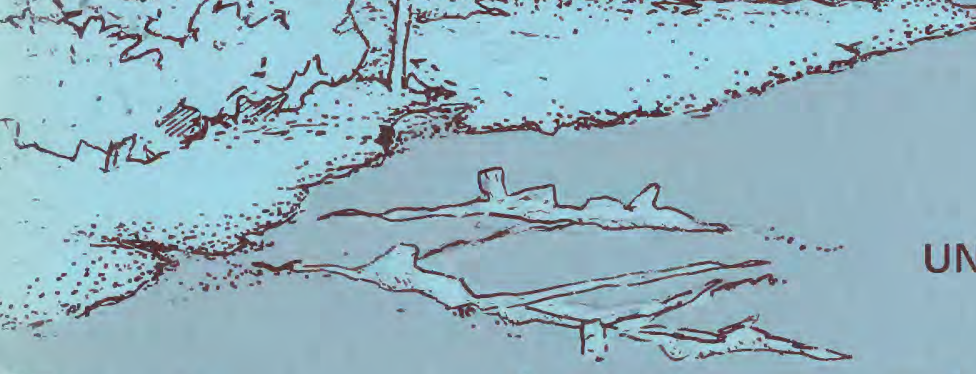

PREPARED BY

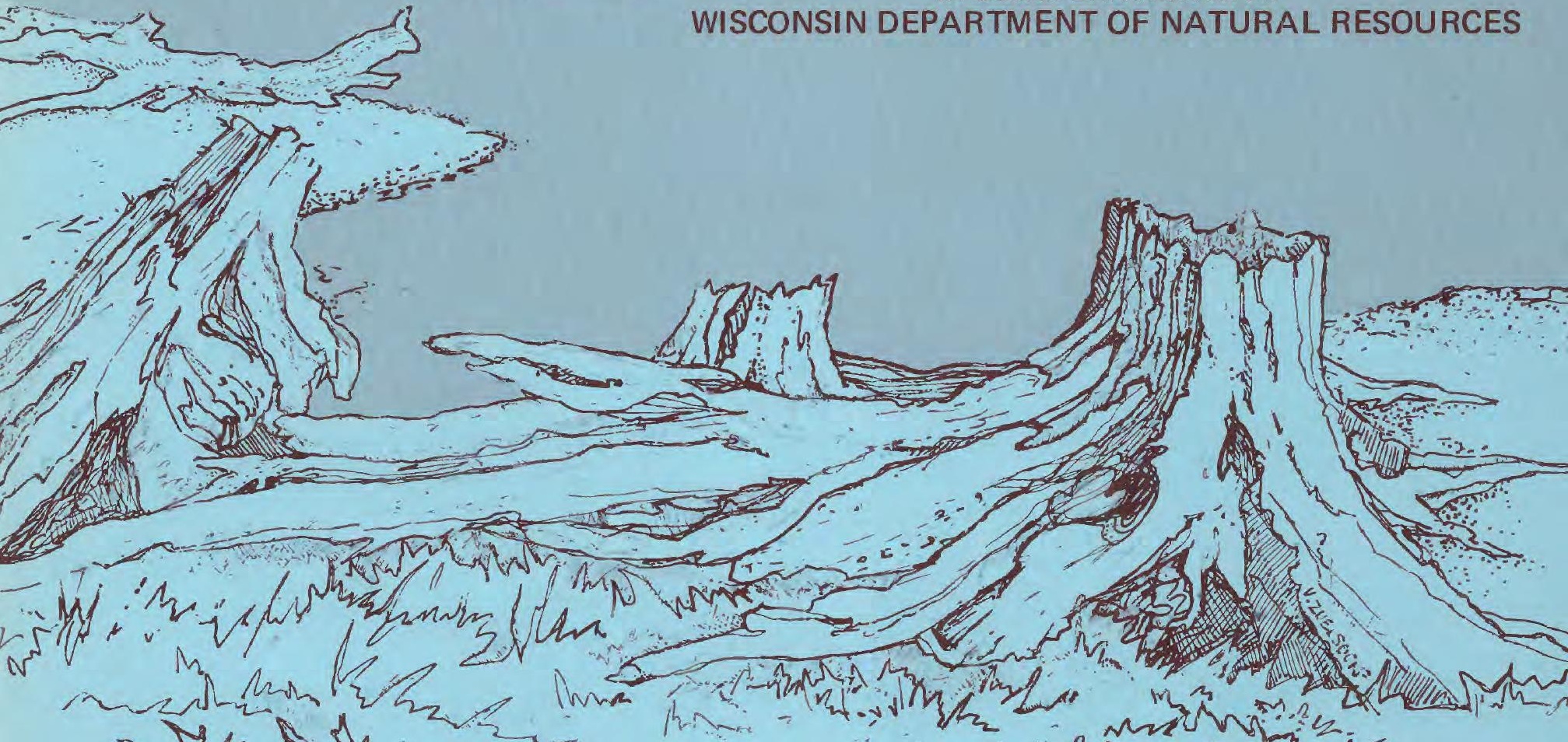
GEOLOGICAL SURVEY IN COOOPERATION WITH

UNITED STATES DEPARTMENT OF THE INTERIOR 


\title{
Low-Flow Characteristics of Streams in the Upper Wisconsin River Basin, Wisconsin
}

\author{
W.A. GEBERT
}

U.S. GEOLOGICAL SURVEY

Water Resources Investigations

Open-File Report 80-691

Prepared in cooperation with the

Wisconsin Department of Natural Resources

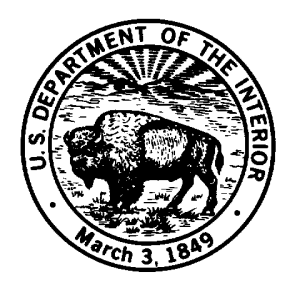

July 1980 


\section{UNITED STATES DEPARTMENT OF THE INTERIOR}

CECIL D. ANDRUS, SECRETARY

\section{GEOLOGICAL SURVEY}

H. William Menard, Director

For additional information write to:

U. S. Geological Survey

1815 University Avenue

Madison, Wisconsin 53706 


\section{CONTENTS}

$\underline{\text { Page }}$

Abstract--_-_-_-_-_-_-_ I

Explanation of terms-_- 2

Introduction-- 2

Basin description-_-_-_-_- 4

Low-flow characteristics-_-_ 5

Analytical techniques-_-_-_-_-_- 5

Gaging stations-_-_- 7

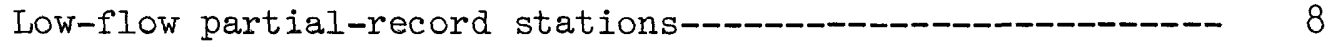

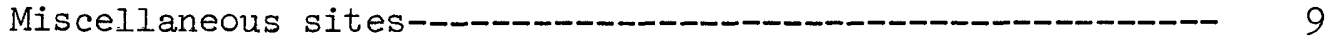

Accuracy-_-_- 11

Gaging stations-_-_-_-_- 11

Low-flow partial-record stations-_-_- 11

Miscellaneous sites-_-_-_-_-_-_-_-_-_-_-_-_-_-_-_-_--- 11

Estimating low-flow characteristics at ungaged sites-_._-_-_-_-_-_ 12

Streamflow characteristics-_-_-_-_- 12

Basin characteristics-_-_-_-_-_- 12

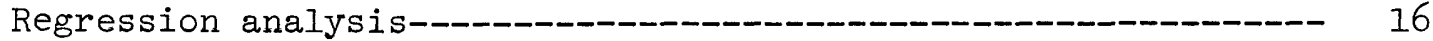

Sites without streamflow data-_-_-_-_-_-_-_-_-_-_--- 17

Sites with minimum streamflow data-_-n 18

Verification of regression equations that use base-flow

index--_-_- 19

Application of estimating procedures-_-_- 19

Sites without streamflow data-_- 19

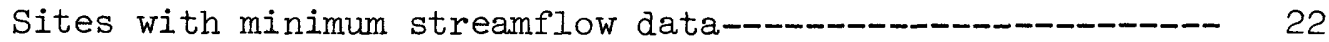

Comparison of methods-_- 24

Summary-- 25

References-_- 25

\section{ILLUSTRATIONS}

Plate 1. Location of gaging stations, low-flow partial-record stations, and miscellaneous sites in the upper Wisconsin River basin, Wisconsin

2. Base-flow index values for selected stations and sites in the upper Wisconsin River basin, Wisconsin

$\underline{\text { Page }}$

Figure 1. Map showing location of the upper Wisconsin River basin in Wisconsin-_-_-_-_-

2. Hydrograph of daily discharge of Prairie River near Merrill for 1965 climatic year showing annual lowflow periods for various number of days---_--_--_---

3. Low-flow frequency curves of the annual lowest mean discharge for the indicated number of consecutive days at Prairie River near Merrill during the period 191431, 1939-77-_-_- 
Page

4. Flow-duration curve showing the percentage of time a given discharge was exceeded for Prairie River near

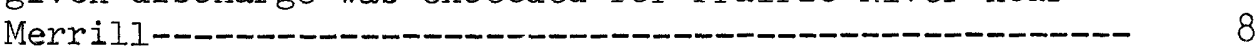

5. Graph showing method of estimating $Q_{7,2}$ and $Q_{7,10}$ at low-flow partial-record stations-_- 9

6. Graph showing method of estimating $Q_{7,2}$ and $Q_{7,10}$ at miscellaneous sites-_-_-_.-.- 10

7. Map showing glacial geology and drift thickness in the upper Wisconsin River basin, Wisconsin-

\section{TABLES}

Page

Table 1. Low-flow characteristics for sites in the upper Wisconsin River basin--

2. Drainage-basin characteristics for low-flow partial-record stations and selected gaging stations in the upper Wisconsin River basin-- 58

3. Comparison of methods available to estimate low-flow characteristics in the upper Wisconsin River basin------ 


\title{
Low-Flow Characteristics of Streams in the Upper Wisconsin River Basin, Wisconsin
}

\author{
W.A. GEBERT
}

\begin{abstract}
This report describes low-flow characteristics of streams in the upper Wisconsin River basin where streamflow data have been collected and presents equations for estimating low-flow characteristics at ungaged sites. Included are estimates of low-flow frequency at 10 gaging stations, flow duration at 8 gaging stations, and low-flow frequency characteristics at 13 low-flow partialrecord stations and 81 miscellaneous sites.

Six equations are provided to estimate low-flow characteristics at ungaged sites and at sites where one base-flow discharge measurement is available. The relationships were determined from multiple-regression analyses that related the low-flow characteristics at gaging stations and low-flow partial-record stations to basin characteristics. Drainage area (A), hydraulic conductivity (K), and drift thickness ( $H$ ) were the most significant characteristics in explaining the variations in low flow for ungaged sites. The equations and standard error of estimates (SE) for ungaged sites are:

$$
\begin{array}{rlrl}
Q_{7,2}=1.82 \times 10^{-3} \mathrm{~A} & 0.782 \mathrm{~K}^{0.254} \mathrm{H}^{0.804} & \mathrm{SE}_{7,2} & =81 \text { percent } \\
Q_{7,10}=4.94 \times 10^{-4} \mathrm{~A} & 0.817_{\mathrm{K}} 0.295 \mathrm{H}^{0.909} & \mathrm{SE}_{7,10} & =113 \text { percent }
\end{array}
$$
\end{abstract}

For sites where one base-flow measurement has been made drainage area (A), hydraulic conductivity $(\mathrm{K})$, and base-flow index (Bf) were the most significant characteristics. The equations and standard error of estimate are:

$$
\begin{aligned}
& Q_{7,2}=0.242 A^{0.971_{K}} 0.140_{\mathrm{Bf}^{0.711}} \mathrm{SE}_{7,2}=36 \text { percent } \\
& Q_{7,10}=0.156 \mathrm{~A}^{1.04} \mathrm{~K}^{0.144} \mathrm{Bf}^{0.881} \quad \mathrm{SE}_{7,10}=48 \text { percent }
\end{aligned}
$$


Low-flow characteristics estimated for the upper Wisconsin River basin have a moderately high standard error of estimate compared with other basins in Wisconsin. This reflects the large variability of low flow for streams in the upper Wisconsin River basin which is due in part to flow regulation or evapotranspiration caused by the large number of lakes and wetlands.

\section{EXPLANATION OF TERMS}

Base flow--That part of the streamflow derived from ground water.

Low flow--The minimum stream discharge that occurs within a given time period.

Continuous-record gaging station--A station where continuous streamflow data are collected.

Low-flow partial-record station--A station where eight or more base-flow discharge measurements are made in at least a 2-year period to determine low-flow characteristics.

Miscellaneous site--A site where less than eight base-flow discharge measurements have been made as part of other water-resources investigations or to determine the stream's base-flow characteristic for this report.

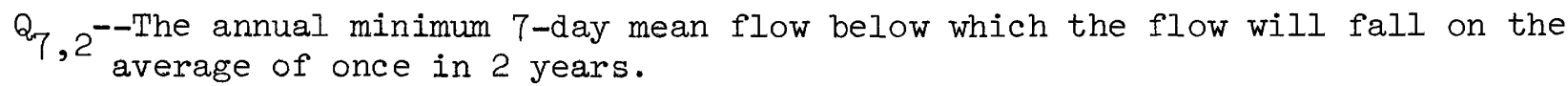

$Q_{7,10^{--T h e}}$ annual minimum 7 -day mean flow below which the flow will fall on the
average of once in 10 years.

Standard error of estimate ( $\mathrm{SE}$ )--Is a range such that values estimated by a method are within this range at about 67 percent of the sites, and are within twice the range at about 95 percent of the sites.

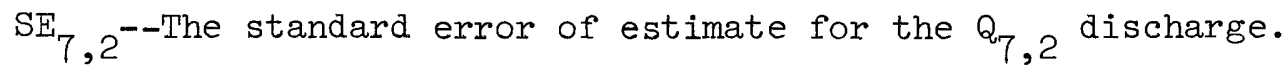

$\mathrm{SE}_{7,10^{--T h e}}$ standard error of estimate for the $Q_{7,10}$ discharge.

\section{INTRODUCTION}

The purpose of this report is to describe low-flow characteristics of streams in the upper Wisconsin River basin where streamflow data have been collected and to present equations for estimating low-flow characteristics at ungaged sites.

This study was done in cooperation with the Wisconsin Department of Natural Resources. This report is part of a series of 12 planned reports to describe low-flow characteristics of the major basins in Wisconsin (fig. 1).

The report includes: estimates of the magnitude and frequency of recurrence of low flow for various sites where systematic streamflow information has been collected, low-flow discharge measurements that have been obtained at numerous 


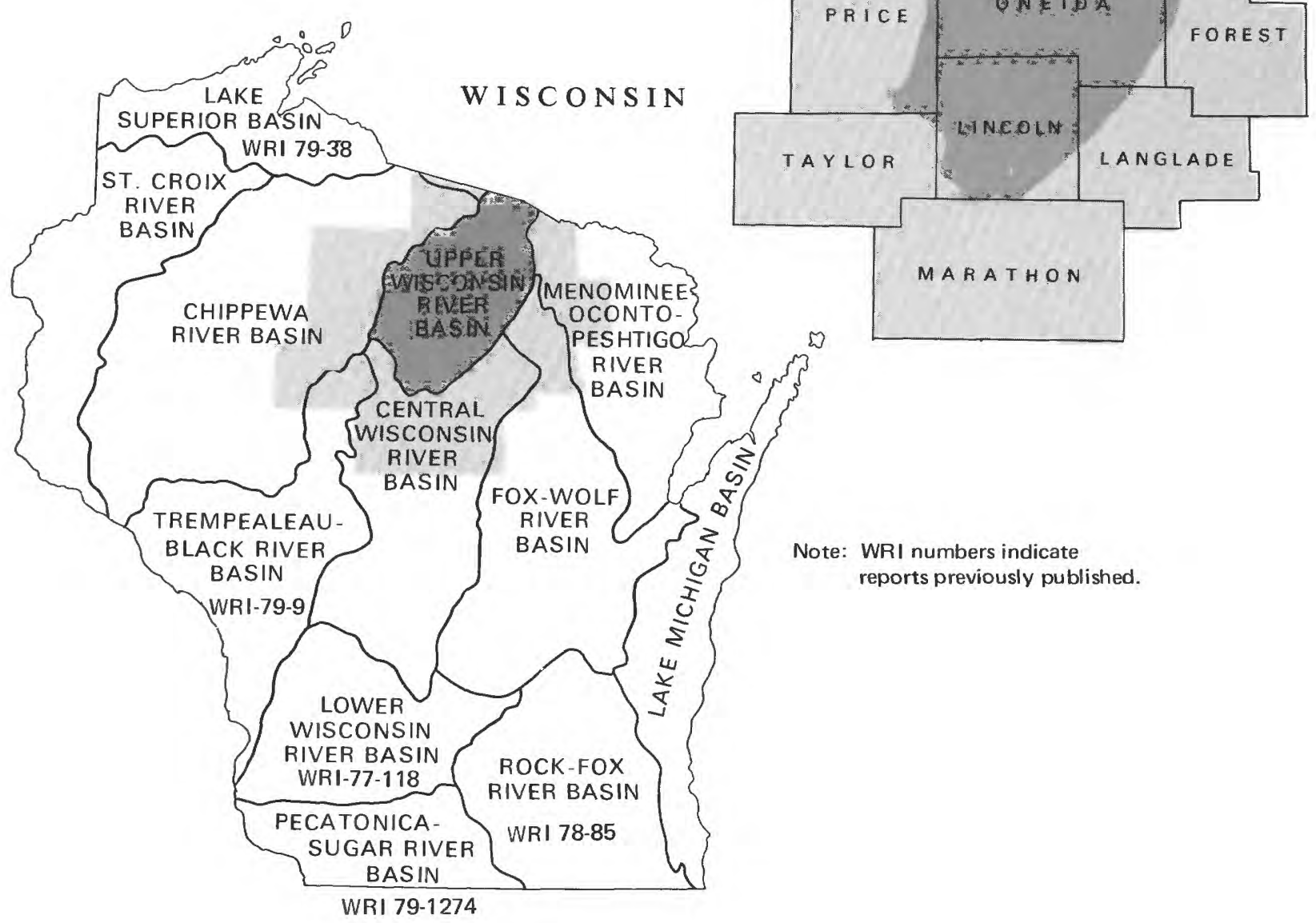

Figure 1. Location of the upper Wisconsin River basin in Wisconsin.

sites throughout the basin, and a method to estimate low-flow characteristics at ungaged sites and at sites with minimum streamflow data available.

In recent years, a great demand has been placed on water resources in Wisconsin by increased multiple uses such as: maintenance of fish and wildlife habitat, irrigation of crops, dilution and assimilation of wastes, production of hydropower, construction of impoundments for real-estate developments, and maintenance of adequate flow for canoeing. This increased demand requires an accurate determination of water resources during low-flow periods to ensure proper consideration of all users.

Low-flow frequency analyses and flow-duration analyses are presented for all current and discontinued gaging stations in the upper Wisconsin River basin. 
These analyses have been completed for eight gaging stations through water year 1976. Low-flow frequency data are included in the report for 13 low-flow partialrecord stations and for 81 miscellaneous sites.

Previous reports by Holmstrom (1979) and Gebert (1971) contain preliminary information on low-flow characteristics of this basin.

For the convenience of readers who prefer metric units, the data may be converted by using the following factors:

Multiply

mile $(\mathrm{mi})$

foot ( $\mathrm{ft}$ )

square mile $\left(\mathrm{mi}^{2}\right)$

cubic foot per second $\left(\mathrm{ft}^{3} / \mathrm{s}\right)$

foot per mile ( $\mathrm{ft} / \mathrm{mi}$ )

inch (in.)

cubic foot per second per

square mile $\left\{(\mathrm{ft} 3 / \mathrm{s}) / \mathrm{mi}^{2}\right\}$

gallon per day (gal/d)

gallon per day per square

foot $\left\{(\mathrm{gal} / \mathrm{d}) / \mathrm{ft}^{2}\right\}$

\section{By \\ To obtain}

1.609

0.3048

2.59

0.02832

0.1894

2.54

0.01094

0.003786

$3.517 \times 10^{-4}$

meter $(\mathrm{m})$ kilometer $(\mathrm{km})$

square kilometer $\left(\mathrm{km}^{2}\right)$

cubic meter per second $\left(\mathrm{m}^{3} / \mathrm{s}\right)$

meter per kilometer $(\mathrm{m} / \mathrm{km})$

centimeter $(\mathrm{cm})$

cubic meter per second per square kilometer $\left\{\left(\mathrm{m}^{3} / \mathrm{s}\right) / \mathrm{km}^{2}\right\}$

cubic meter per day $\left(\mathrm{m}^{3} / \mathrm{d}\right)$

cubic meter per day per

square meter $\left\{\left(\mathrm{cm}^{3} / \mathrm{d}\right) / \mathrm{m}^{2}\right\}$

\section{BASIN DESCRIPTION}

The upper Wisconsin River basin is the headwaters of the Wisconsin River in northern Wisconsin. The basin includes the area upstream from the gage on the Wisconsin River at Merrill. The drainage area for the basin is 2,758 $\mathrm{mi}^{2}$, which includes about $50 \mathrm{mi}^{2}$ in the state of Michigan.

The basin is mainly a rural area with a population of about 68,000 people in 1976. The largest cities are Merrill, Rhinelander, and Tomahawk with populations of $9,373,8,643$, and 3,810 , respectively. The economy is diversified with agriculture, forestry, and tourism being the major sources of employment. Hay and dairy farming are the principal agricultural activities and the pulp-logging industry is the major forest activity. Tourism is the major activity in the northern lake portion of the basin with Eagle River, Minocqua-Woodruff, and Rhinelandex being major tourist centers in the State. The papermill industry is the largest industrial employer in the basin with large mills located in Merrill, Rhinelander, and Tomahawk.

The mean annual precipitation for the basin is $31.3 \mathrm{in.} \mathrm{(Wisconsin} \mathrm{Statistical}$ Reporting Service, 1967), ranging from more than $33 \mathrm{in.}$ in the west edge of the basin to $30 \mathrm{in.}$. in the eastern edge of the basin. Snowfall in the basin ranges from near $80 \mathrm{in.}$ in the northern part of Vilas County to $50 \mathrm{in}$. in Lincoln and Langlade Counties. The mean annual runoff from the basin is 12.4 in. and the mean annual evapotranspiration is $18.9 \mathrm{in.} \mathrm{(Oakes} \mathrm{and} \mathrm{Cotter,} \mathrm{1975).}$

The upper Wisconsin River basin has an irregular glacial landscape consisting of rolling ground moraine, hills and ridges of end moraine, and pitted outwash 
plains. The outwash plains and ice-contact topography contains more than 2,000 lakes which is an indication of the poor drainage in the basin.

The elevation of the land surface ranges from 1,240 ft at Merrill to 1,952 ft at the top of Timms Hill in Price County. This is also the highest point in the State.

The bedrock in the basin is Precambrian igneous or metamorphic rock. Rock types include granite, diorite, schist, gneiss, quartzite, slate, and greenstone (Dutton and Bradley, 1970, p. 9, 11, 12, and sheet 1). Generally the bedrock surface has an altitude between 1,400 and 1,600 ft.

Glacial drift overlies the bedrock and ranges from 0 to $240 \mathrm{ft}$ thick with an average of about $100 \mathrm{ft}$ thick. The drift stores substantial quantities of water for release to streams or wells. Types and locations of glacial deposits and bedrock geology are described by Oakes and Cotter (1975).

\section{LOW-FLOW CHARACTERISTICS}

Low flow generally refers to the low range of stream discharge. A probability of occurrence and a time period can be specified for a more precise definition. Low flow is usually ground-water discharge or base flow, although a 30-, 60-, or 90-day low flow could contain some direct or storm runoff.

A typical low-flow period is illustrated by the discharge hydrograph for the Prairie River near Merrill gaging station (fig. 2). The annual 90-day low flow occurred from June 17 to September 15. Although this was the lowest flow for 90 consecutive days during the year, periods of substantial direct runoff occurred on many occasions during this period. Except for the rises resulting from direct runoff, the streamflow for the period was base flow or ground-water discharge.

Base flow is very important for many low-flow studies because during this period stream discharge is the most stable. Thus, low-flow characteristics can be transferred from a stream where systematic streamflow records have been collected for a period of years to a nearby stream where only a minimum amount of base-flow discharge measurements are available.

Table 1 contains low-flow characteristics for 104 sites in the upper Wisconsin River basin. Each site is identified by station number and station name. The site location, drainage area, type of site, base-flow discharge measurements, and other pertinent data are included. Characteristics included for each site depend upon the type of site: gaging station, low-flow partial-record station, or miscellaneous sites. The locations of the sites are shown on plate 1.

\section{ANALYTICAL TECHNIQUES}

Low-flow characteristics in table 1 were determined by three methods of analysis. These methods depended on the three basic types of data available: (1) continuous record of daily streamflows (continuous-record gaging stations);

(2) 11 to 17 base-flow discharge measurements (low-flow partial-record stations);

(3) 1 to 4 base-flow discharge measurements (miscellaneous sites). 


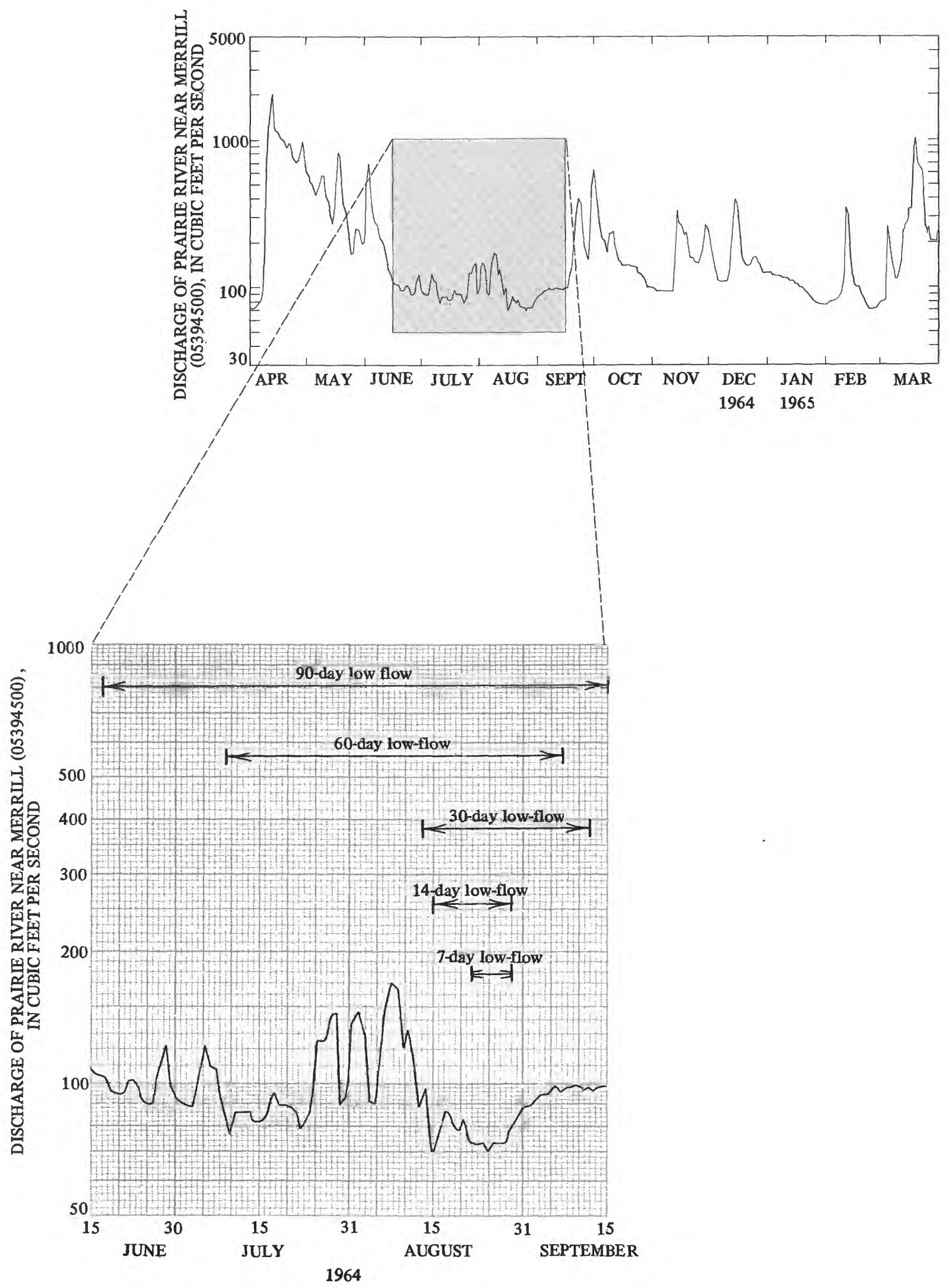

Figure 2. Daily discharge of Prairie River near Merrill, for 1965

climatic year, showing annual low-flow periods for various numbers of days. 


\section{Gaging stations}

Low-flow characteristics of a stream where systematic streamflow records have been collected can be determined by flow-duration analysis or frequency analysis. The two analyses serve different purposes. The flow-duration curve indicates the percentage of time that a daily mean flow exceeds a given discharge and the low-flow frequency curve indicates the probability that a 7-day, 14-day, 30-day, 60-day, and 90-day consecutive mean flow will be exceeded in any given year. The recommended and more generally used analysis for most low-flow applications is the low-flow frequency analysis. In the upper Wisconsin River basin the annual minimum 7-day mean flow below which the flow will fall on the average of once in 2 years $(47,2)$ is approximately equal to 92 percent flow duration. The annual minimum 7-day mean flow below which the flow will fall on the average of once in 10 years $\left(Q_{7,10}\right)$ is about equal to 99.6 percent flow duration.

Low-flow frequency and flow-duration analyses were completed for all continuous-record gaging stations that have at least 10 years of record. Lowflow frequency values are listed in table 1 showing the magnitude and frequency of annual low flows for 3, 7, 14, 30,60, and 90 consecutive days. Table 1 also lists flow-duration values showing the percentage of time that specified discharges were exceeded.

The low-flow frequency characteristics were determined from the daily discharge records using a log-Pearson Type III probability distribution. The results of these analyses were compared to graphs of the annual minimum flows for the various consecutive days (Riggs, 1972). If the two curves did not agree, a graphical interpretation was made to determine the various low-flow characteristics. Figure 3 is an example of a low-flow frequency curve for the

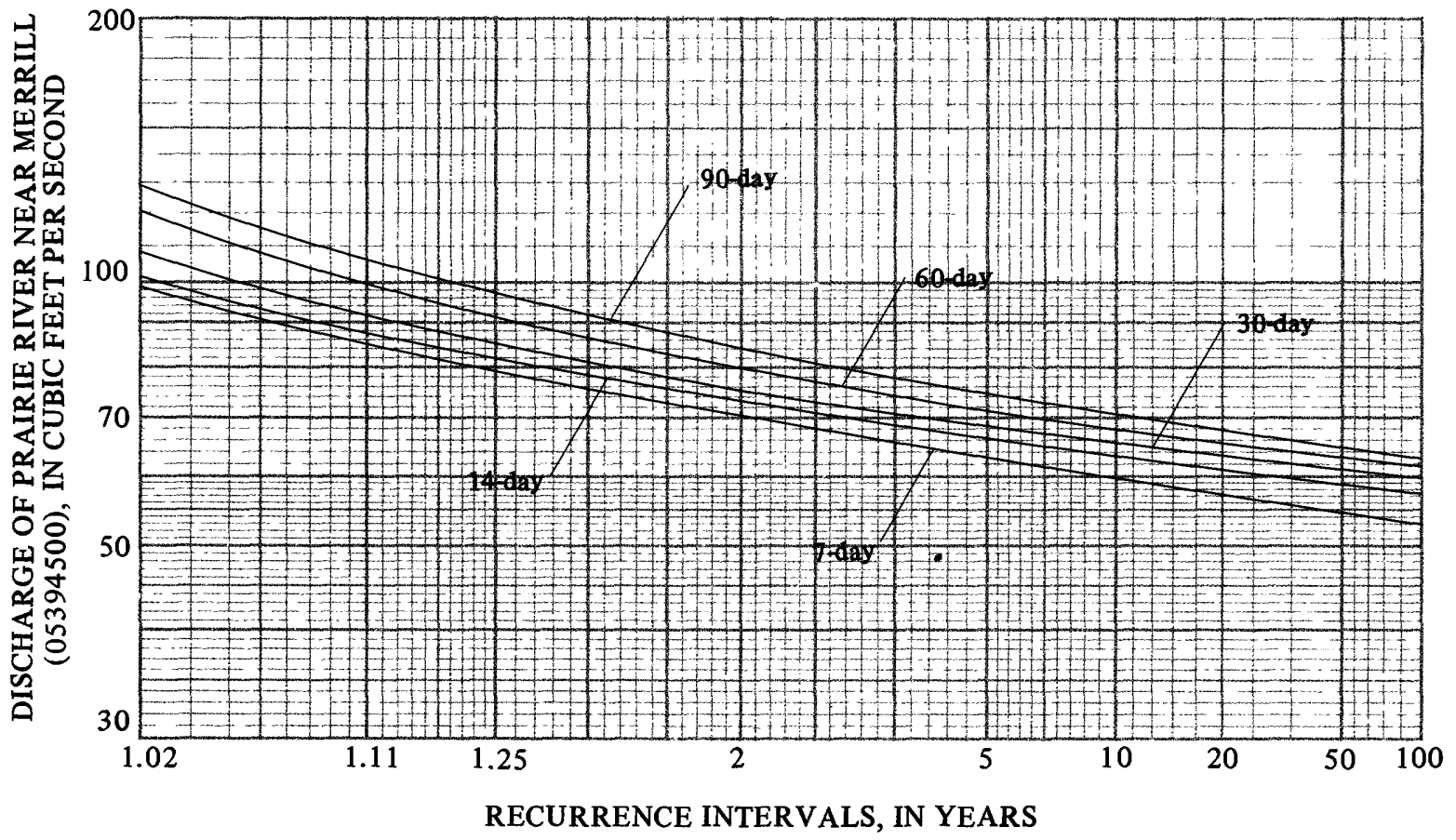

Figure 3. Low-flow frequency curves of the annual lowest mean discharge for the in dicated number of consecutive days at Prairie River near Merrill. 
Prairie River near Merrill gaging station, and figure 4 is a flow-duration curve for the same site.

For gaging stations that have insufficient data for low-flow frequency analysis or flow duration, the low-flow characteristics were determined by a procedure similar to that outlined in the following section for low-flow partialrecord stations.

\section{Low-flow partial-record stations}

Low-flow characteristics determined for low-flow partial-record stations are $Q_{7,2}$ and $Q_{7,10}$. Estimates of $Q_{7,2}$ and $Q_{7,10}$ are presented in table 1 for 13 low-flow partial-record stations. 'Characteristics were determined from a relation line established by a graphical regression using 11 to 17 base-flow discharge measurements at low-flow partial-record stations with concurrent discharges at continuous-record gaging stations in the area (Gebert, 1971). The Q7,2 and $Q_{7,10}$ at the continuous-record gaging station then were transferred through the relation line to estimate $Q_{7,2}$ and $Q_{7,10}$ for the partial-record station. Figure 5 is an example of this type of analysis for Noisy Creek near Rhinelander.



Figure 4. Flow-duration curve showing the percentage of time a given discharge was exceeded for Prairie River near Merrill during the period 1914-31, 1939-77. 


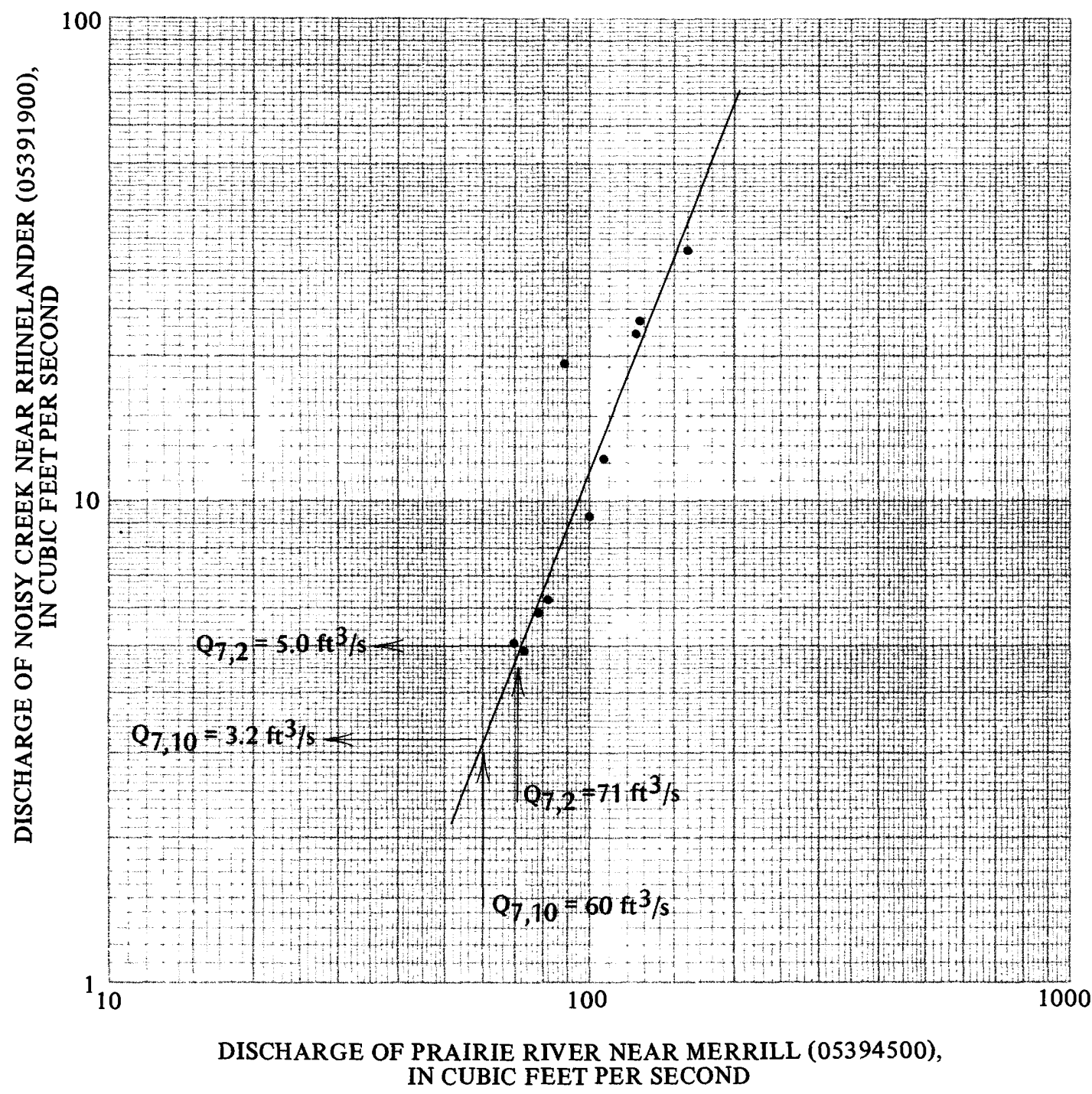

Figure 5. Method of estimating $Q_{7,2}$ and $Q_{7,10}$ at low-flow partial -record stations.

\section{Miscellaneous sites}

Base-flow measurements have been obtained at 99 miscellaneous sites in the upper Wisconsin River basin as part of other water-resources investigations. Low-flow characteristics were estimated for most of these sites (table l) by one of two methods.

Estimates of 87,2 and 47,10 were made at 17 sites by the same type of analysis that was used for partial-record stations (Gebert and Holmstrom, 1974) for the following conditions: if at least three base-flow discharge measurements were available and a well-defined relationship existed between the measured discharge and the concurrent daily mean discharge at a nearby gaging station. Figure 6 illustrates this type of analysis for Squaw Creek near Spirit.

The slope of the relation line for miscellaneous sites was compared to established relation lines of nearby low-flow partial-record stations and other miscellaneous sites for uniformity. Generally the relation line should have approximately the same slope if the factors that influence low flow are uniform for the area. If the relation line at the site being studied was defined by 


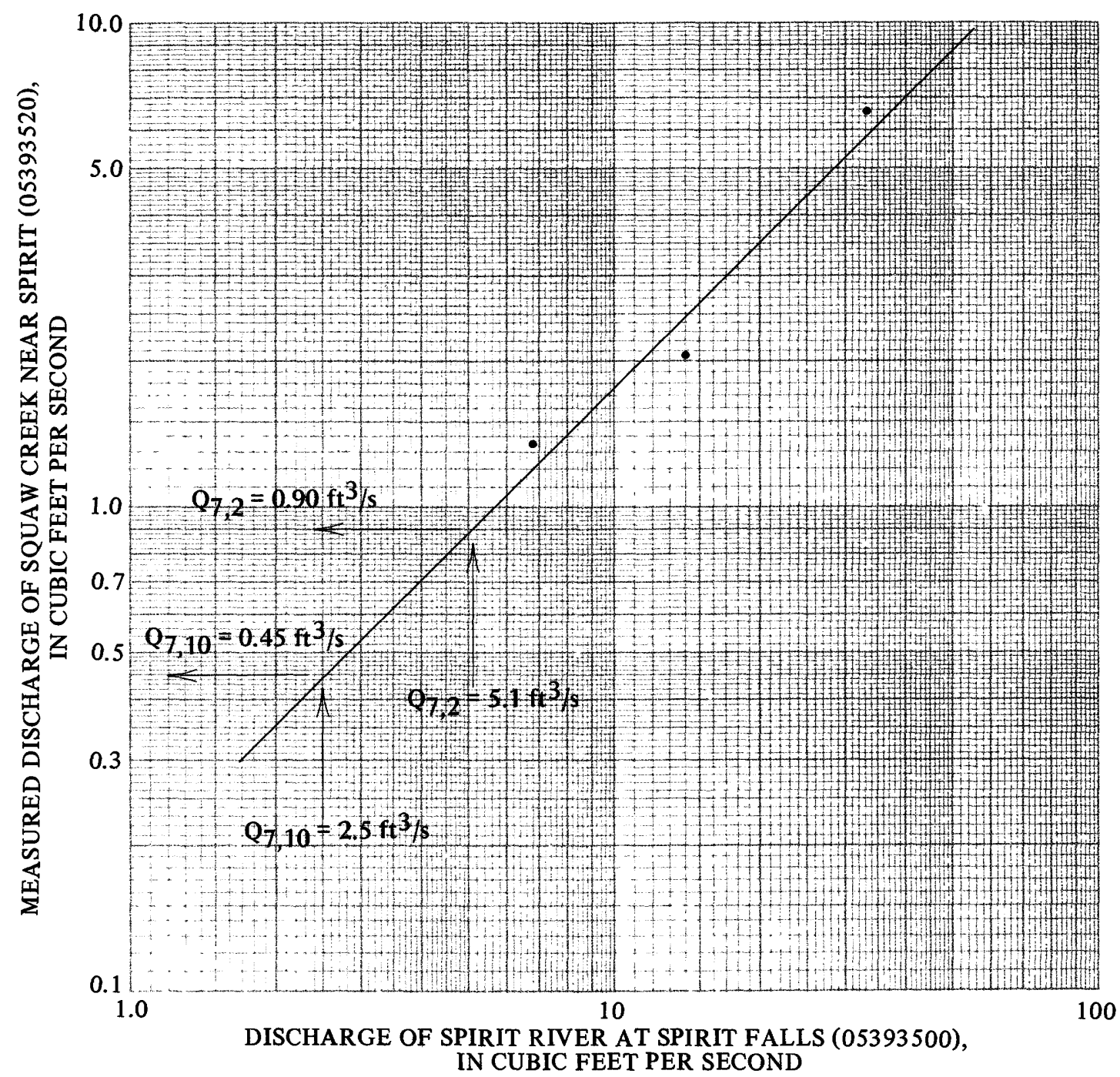

Figure 6. Method of estimating $Q_{7,2}$ and $Q_{7,10}$ at miscellaneous sites.

three discharge measurements that had significant scatter, the line was adjusted to agree more closely with the better established relation line at a low-flow partial-record station.

For 64 miscellaneous sites that have less than 3 discharge measurements, the low-flow characteristics were estimated by regression equations. The regression equations used and discussion of their development are presented later in the report ( $p .12-19)$.

Low-flow characteristics were not estimated at 13 miscellaneous sites for one or more of the following reasons: discharge measurements were affected by upstream regulation or contained substantial effluent from industrial or sewagetreatment plant discharge, less than 3 discharge measurements were available but the site had a drainage area greater than $184 \mathrm{mi}^{2}$, or regression equations provided estimates that were obviously poor when compared to existing data at nearby sites. 


\section{ACCURACY}

The low-flow characteristics in table 1 are estimates of flow expected in the future. Low-flow characteristics like other streamflow characteristics are only estimates, with their true value being difficult or impossible to determine. The estimates are based on data collected at each site and analyzed by several methods. Each estimate has an error associated with it, dependent on the amount and kind of data, and the analytical method. Two major sources of error are the time-sampling error in streamflow records and the error in the analytical method.

The expected degree of accuracy for the $Q_{7,2}$ and $Q_{7,10}$ estimates are presented in table 1 for each site. The accuracy is determined by the standard error of estimate for the 7-day, 2-year low flow $\left(\mathrm{SE}_{7,2}\right)$ and for the 7-day, 10-year low flow $\left(\mathrm{SE}_{7}, 10\right)$. The standard error of estimate is a range such that the values estimated by the method are within this range at about 67 percent of the sites, and are within twice this range at about 95 percent of the sites.

The methods used to obtain the standard errors are not precise, and the standard errors presented in the table should be used as a relative guide to indicate a general level of confidence. In addition, there may be greater error associated with accuracy estimates for low-flow estimates that approach $0 \mathrm{ft} 3 / \mathrm{s}$.

\section{Gaging stations}

Accuracy of low-flow characteristics at gaging stations was determined according to Hardison and Moss (1969). An average $\mathrm{SE}_{7,2}$ of 6 percent and $\mathrm{SE}_{7,10}$ of 9 percent was determined for the three gaging stations in the upper Wisconsin River basin that had greater than 10 years of unregulated-streamflow record.

A common length of record was used to compare the accuracy of low-flow characteristics determined from recorded discharge at gaging stations in the upper Wisconsin River basin with that of gaging stations throughout the State. This analysis assumed that 10 years of record was available at each gaging station to determine the $Q_{7,10}$ discharge. An $\mathrm{SE}_{7,10}$ of 14 percent was determined for the upper Wisconsin River basin as compared to an $\mathrm{SE}_{7,10}$ of 16 percent for gaging stations throughout the State. This comparison may not adequately evaluate the overall accuracy that can be achieved at gaging stations because only three stations were available for analysis. This is especially true since one of the stations is the Prairie River at Merrill which has a high and stable base-flow discharge, providing very accurate determination of low-flow characteristics. Both $\mathrm{SE}_{7,2}$ and $\mathrm{SE}_{7,10}$ are 2 percent for this station.

\section{Low-flow partial-record stations}

The accuracy of low-flow characteristics at low-flow partial-record stations was determined by a method developed by Hardison and Moss (1972). Using this method, an average $\mathrm{SE}_{7,10}$ of 29 percent was found for the 13 low-flow partialrecord stations in the upper Wisconsin River basin. This compares to an average $\mathrm{SE}_{7,10}$ of 29 percent for 265 low-flow partial-record stations throughout the State.

\section{Miscellaneous sites}

The accuracy of low-flow characteristics that were determined by graphical regression using discharge measurements at the 10 miscellaneous sites is an 
average value for the entire basin. It was determined by analyzing data collected at low-flow partial-record stations. Three random base-flow measurements were selected from the 11 to 17 measurements available at the 13 low-flow partialrecord stations. Low-flow characteristics were determined from these three measurements using the same procedure used for miscellaneous sites. Then lowflow characteristics determined by this method were plotted against the low-flow characteristics based on 11 to 17 measurements. The SE between the two methods was determined from this plotted relationship. The overall SE includes the SE determined by the plotted relationship and the SE associated with the low-flow estimates based on 11 to 17 measurements. Assuming the two errors are independent, the overall SE can be approximated by taking the square root of the sum of the squares of the two different SE's. For the upper Wisconsin River basin this resulted in an $\mathrm{SE}_{7,10}$ of 38 percent which is listed in table 1 as the average basin accuracy.

The average $\mathrm{SE}_{7,10}$ value should be used cautiously for any particular site since the actual value for a subbasin could be significantly different from the mean for the basin. If the low-flow characteristics are based on more than three discharge measurements, the accuracy probably will be improved and should approach the accuracy at low-flow partial-record stations as additional measurements are obtained.

The accuracy of the low-flow characteristics that were determined by regression equations at the other 64 miscellaneous sites is also an average value for the basin. It was determined as part of the regression analysis and is discussed later in the report (12-19).

\section{ESTIMATING LOW-FLOW CHARACTERISTICS AT UNGAGED SITES}

A method is required to transfer low-flow characteristics from gaged sites to ungaged sites because it is impossible to obtain actual streamflow data for all sites where the information is needed. The most practical transfer method relates low-flow characteristics to climatic, topographic, and aquifer characteristics of the drainage basin by multiple-regression analysis. Characteristics used in the multiple-regression analysis and the equations determined are discussed in the following paragraphs. The method is outlined in detail by Thomas and Benson (1970).

\section{STREAMFLOW CHARACTERISTICS}

Streamflow characteristics that were studied are the Q7,2 and 47,10 which are widely used to describe low flow. The multiple-regression analysis included low-flow characteristics for 3 gaging stations and 13 low-flow partial-record stations in the upper Wisconsin River basin. The streamflow characteristics are the dependent variable in the multiple-regression analysis.

\section{BASIN CHARACTERISTICS}

Differences in streamflow for various locations and times are caused by the differences in precipitation patterns and the differences in runoff characteristics. Climatic, topographic, and aquifer characteristics are quantified to explain the variation in low flow. These indices are the independent variables in the multiple-regression analysis. 
Basin characteristics were selected for the analyses because of their known influence on the rainfall-runoff process. The following list of the drainagebasin characteristics contains a brief discussion of their effect on low flow and how the indices were determined.

Values for these basin characteristics for low-flow partial-record stations and selected gaging stations (drainage areas less than $184 \mathrm{mi}^{2}$ ) in the upper Wisconsin River basin are listed in table 2.

Drainage area (A).--Size of the drainage area is the most significant characteristic in explaining differing streamflow between sites. Because low flow is ground-water runoff, the contributing area is defined by the groundwater divide of a basin which can be determined from potentiometric maps. Because detailed potentiometric maps are not available for most areas in the upper Wisconsin River basin, the surface-water divide was used to define the contributing drainage area.

Drainage areas, in square miles, were computed from U.S. Geological Survey topographic maps. Most drainage-area data for this study were obtained from Holmstrom (1972).

Main-channel slope (S).--Main-channel slope (Benson, 1962 and 1964) is a characteristic that relates to the change in streamflow for different basins. The index of slope used in this analysis is the average slope in feet per mile between points 10 percent and 85 percent of the distance upstream from the gaged site to the drainage-basin divide.

Main-channel length (L).--Main-channel length is another landform characteristic that indicates basin shape in conjunction with drainage area of the basin. In estimating ground-water runoff to the stream, $I$ can be viewed as describing the length of the vertical cross-sectional area of the porous aquifer material through which the flow occurs. Channel length was obtained from the U.S. Geological Survey topographic maps by measuring the total indicated blue-line length by a digitizer, divider, or other means.

Basin storage (Bs).--Basin storage is that part of total drainage area occupied by lakes and marshes. Variations in streamflow can be caused by retention and release of water from basin storage. For some streams, runoff is delayed by storage, but total runoff may not be reduced; whereas on other streams prolonged retention allows increased evapotranspiration that results in decreased runoff. Essentially, the basin storage index is used in the analysis to reflect the effect of evapotranspiration on low flow.

The basin storage area was obtained from U.S. Geological Survey topographic maps. A value of 1.00 percent was added to all values of basin storage to avoid problems of using zero in the regression analysis.

Forest cover (F).--Forests affect streamflow in several ways. Their major influences on low flow are intercepting precipitation before it reaches the ground and transpiration. In the "sand plain" area of Wisconsin, Weeks and Stangland (1971) found that converting 10 percent of the headwater drainage area from grassland to forest would reduce the late summer streamflow by about 5 percent. 
The forest cover index used in this analysis is the percentage of drainage area covered by forests as shown on U.S. Geological Survey topographic maps. A value of 1.00 percent was added to all values of forest cover to avoid problems of using zero in the regression analysis.

Mean annual precipitation (P).--Mean annual precipitation of a basin expresses the amount of water available for potential runoff. The precipitation that infiltrates the soil and passes through the unsaturated zone to the ground-water supply is the source of base flow for a stream. The mean annual precipitation, in inches, for each basin was computed from an isohyetal map determined from precipitation recorded at U.S. Weather Bureau stations (Wisconsin Statistical Reporting Service, 1967, p. 18).

A constant of 20 in. was subtracted from each value for use in the regression analysis. This reduction provides constants and exponents in the regression equation that are more manageable.

Soil-infiltration rate (I).--Soil permeability influences the amount of direct runoff from a storm and the amount of water that infiltrates the soil. The permeability used is an average rate for the basin under average soil and moisture conditions.

Soil types and average permeability, in inches per hour, for each basin were determined from maps by Oakes and Cotter (1975).

Mean annual snowfall ( $\mathrm{Sn}$ ).--Mean annual snowfall, like mean annual precipitation, is an indicator of water available for runoff. For each basin an average mean annual snowfall, in inches, was determined from an isohyetal map determined from snowfall recorded in the period 1930-59 (Wisconsin Statistical Reporting Service, 1970) and average snowfall values from National Weather Service weather stations in the basin (Wisconsin Crop Reporting Service, 1961). A constant of 20 in. was subtracted from each value to provide more manageable constants and exponents in the equations.

Base-flow index (Bf).--A good indicator of a stream's low-flow potential is a discharge measurement made during base-flow conditions. Base-flow measurements provide considerable information about the characteristics of the aquifers supplying outflow to the stream. To use base-flow measurements, it is necessary to convert them to a uniform basis because measurements generally are obtained at various points on the base-flow recession curves. Discharge at the 90 percent flow duration was selected to represent the base-flow index value. To evaluate the technique and develop the necessary relationships for this study, sites were selected that had discharge measurements obtained for various low-flow investigations.

Measured discharges $\left(Q_{m}\right)$ at low-flow partial-record stations and miscellaneous sites were converted to a unit discharge by dividing the values by their respective drainage areas (A). These values then were adjusted by a basin ratio to determine the base-flow index for each site. Basin ratios were determined for gaging stations on unregulated streams within the upper Wisconsin River basin by dividing the discharge at 90 percent flow duration (Q9o) by the observed daily discharge $\left(Q_{r}\right)$ on the day discharge $\left(Q_{m}\right)$ was measured during a low base-flow period. Thus, base-flow index values were determined by the equation: 


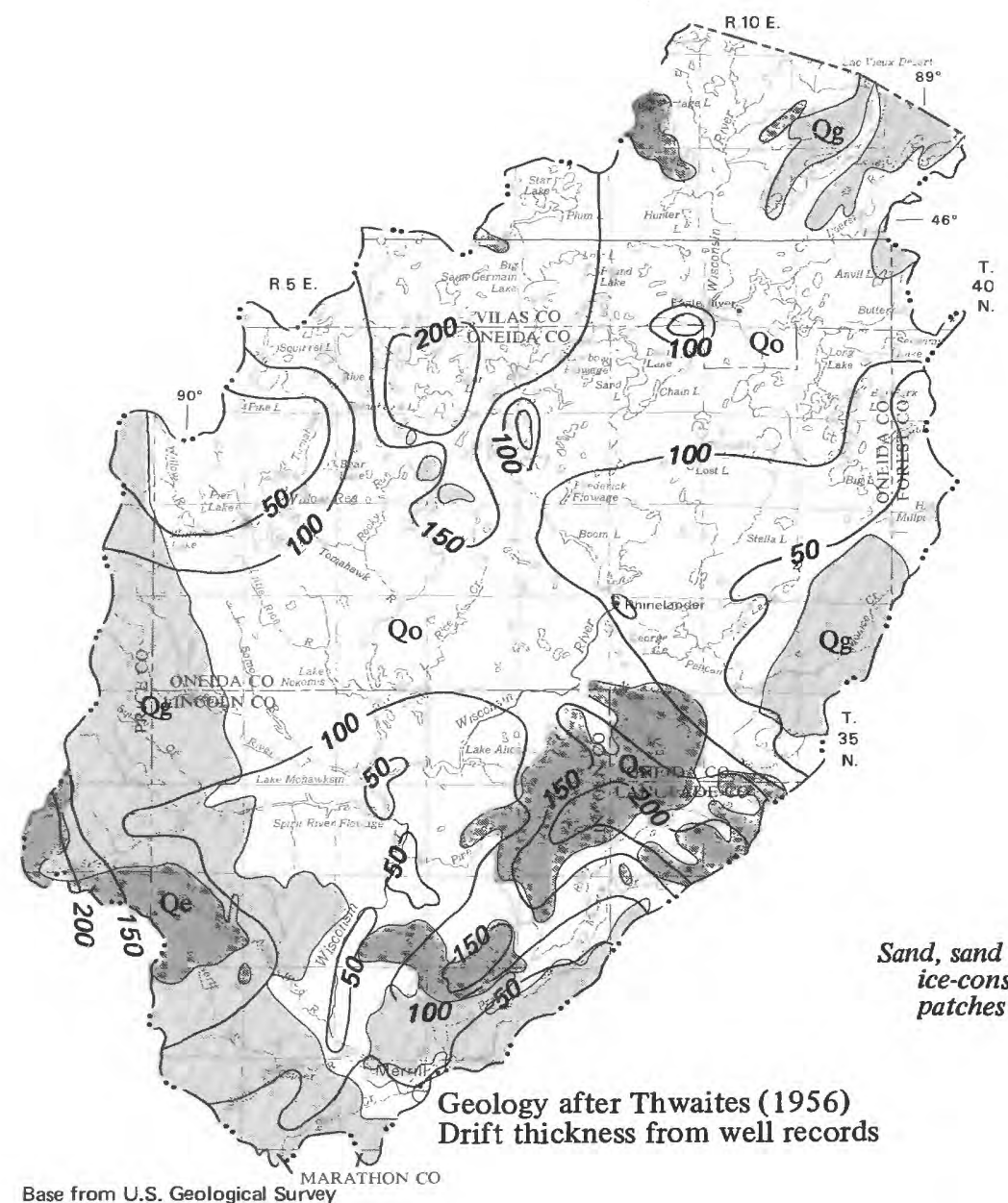

Base from U.S. Geological Survey State base map, 1968

SCALE 1:1,000,000

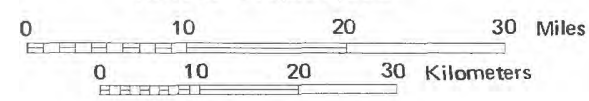

\section{EXPLANATION}

STRATIFIED DRIFT

\section{Qo}

Outwash and ice-contact deposits

sand and gravel; includes pitted and unpitted outwash and ice-constant features on the flank of end moraines. Small patches of ground moraine may occur in this area

\section{UNSTRATIFIED DRIFT

$$
\mathrm{Qg}
$$

Ground moraine

Till, consists of clay, silt, sand, pebbles, cobbles, and boulders

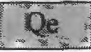

End moraine

Till; includes some minor ice-contact stratified drift

200

Line of equal thickness of glacial drift Interval 50 feet

Surface-water divide

Figure 7. Glacial geology and drift thickness in the upper Wisconsin River basin, Wisconsin. 


$$
B f=\frac{Q_{m} Q_{90}}{A Q_{r}}
$$

Plate 2 shows the locations of 96 sites with base-flow index values, their respective drainage-area outlines, and their computed base-flow index values.

Hydraulic conductivity $(\mathrm{K})$.--Hydraulic conductivity of an aquifer is the volume of water at the existing kinematic viscosity that will move in unit time under a unit hydraulic gradient through a unit area measured at right angles to the direction of flow. Average values of hydraulic conductivity were given to the glacial drift in the upper Wisconsin River basin and are:

$$
\begin{aligned}
& \text { Hydraulic } \\
& \text { conductivity } \\
& \underline{\left\{(\mathrm{gal} / \mathrm{d}) / \mathrm{ft} \mathrm{t}^{2}\right\}}
\end{aligned}
$$

Ground moraine (till; consists of clay, silt, sand, gravel, and boulders)

$$
\begin{array}{r}
10 \\
100 \\
2,500
\end{array}
$$

End moraine (till; sand and gravel)

Outwash (sand and gravel)

Average values of hydraulic conductivity were obtained for each of the subbasins by the following procedures: (1) outline subbasin divide on glacial geology map (Oakes and Cotter, 1975, sheet 1) (fig. 7), (2) determine the subbasin for each of the glacial drift types, (3) multiply these subareas by the hydraulic conductivity values assigned to the glacial drift, and (4) divide the sum of these products by the sum of the subareas.

Drift thickness (H).--Glacial drift serves as an aquifer that stores water for release to streams in the basin. The thickness of glacial drift ranges from zero in various parts of the basin to $240 \mathrm{ft}$ in parts of the basin. An average drift thickness for each subbasin was determined from the glacial geology and drift thickness map by Oakes and Cotter (1975, sheet 1) (fig. 7).

Transmissivity (T).--The water-transmitting capability of an aquifer is expressed in terms of transmissivity. Values of transmissivity were obtained by the product of hydraulic conductivity and drift thickness.

\section{REGRESSION ANALYSIS}

Multiple-regression analysis was used to determine the relationship between the low-flow characteristics (dependent variables) and the basin characteristics (independent variables). The analysis provides an equation, or series of equations, relating the dependent to the independent variables. This analysis defined mathematical equations of the form:

$$
Q_{T}=a A^{b}{ }_{B}{ }^{b}{ }^{b}{ }^{b}{ }^{b} \ldots \ldots \ldots \ldots \ldots N^{b} \text {, }
$$

where:

$$
\begin{gathered}
Q_{T} \text { is a } 7 \text {-day low-flow characteristic having a T-year } \\
\text { recurrence interval, in cubic feet per second; }
\end{gathered}
$$




$$
\begin{aligned}
& \quad \begin{array}{l}
\text { is a regression constant defined by the regression } \\
\text { analysis; }
\end{array} \\
& A B C \ldots . N \text { are drainage-basin characteristics; and } \\
& b_{1} b_{2} b_{3} \ldots b_{n} \text { are regression coefficients defined by regression } \\
& \text { analysis. }
\end{aligned}
$$

The analysis also defined the standard error of estimate (SE) of the analytical method and the statistical significance of each variable in the equation.

The standard error of estimate is a measure of the accuracy of the regression relationships. It describes a range in error between the defined relationship and the data included in the analysis. Values estimated by the regression equations are within the range of one standard error of estimate at about 67 percent of the sites and within trice this range for 95 percent of the sites.

Step-backward regression analyses were performed by digital computer using procedures outlined by Thomas and Benson (1970). The equations with the lowest standard error of estimate with all variables significant at the 95 percent confidence level were selected as the best equations for prediction.

Two separate sets of analyses were performed to develop equations for sites without streamflow data available and for sites with minimum streamflow data available. One analysis included all the drainage-basin characteristics except for base-flow index, and the other analysis contained all the drainage-basin characteristics including the base-flow index.

Drainage area, drift thickness, hydraulic conductivity, and base-flow index were found the most significant characteristics in explaining the differences in low flow. Although other characteristics may logically explain or quantify the precipitation-runoff process, they do not differ across the area studied and therefore cannot explain the differences in low flow. Mean annual precipitation is an example of this type of characteristic that does not differ enough across the basin.

\section{Sites without streamflow data}

Two equations were selected from the analyses for sites without streamflow data available. The equations and their respective standard error of estimates are:

Equation

$$
\begin{aligned}
Q_{7,2} & =1.82 \times 10^{-3} A^{0.782_{H} 0.804} K^{0.254} \\
Q_{7,10} & =4.94 \times 10^{-4} A^{0.817_{H} 0.909} K^{0.295}
\end{aligned}
$$

$\underline{\text { Standard error }}$

$\mathrm{SE}_{7,2}=81$ percent

$\mathrm{SE}_{7,10}=113$ percent 
$Q_{7,2}$ is the 7-day, 2-year low flow, in cubic feet per second;

$Q_{7,10}$ is the 7-day, 10-year low flow, in cubic feet per second;

$A$ is drainage area, in square miles;

$H$ is the average thickness of glacial drift within a basin, in feet; and

$K$ is the hydraulic conductivity, in gallons per day per square foot.

Equations 1 and 2 apply to sites without streamflow data and for drainage areas less than $184 \mathrm{mi}^{2}$.

\section{Sites with minimum streamflow data}

Two sets of equations were selected from the analyses for sites with minimum streamflow data available. The equations and their respective standard errors of estimate are:

$$
\begin{aligned}
& \text { Equation } \\
& \text { Standard error } \\
& Q_{7,2}=0.242 \mathrm{~A}^{0.971_{\mathrm{K}}} \mathrm{P}^{0.140_{\mathrm{Bf}}} \mathrm{P}^{0.711} \\
& \mathrm{SE}_{7,2}=36 \text { percent } \\
& Q_{7,2}=0.808 \mathrm{~A}^{0.917} \mathrm{Bf}^{0.827} \\
& \mathrm{SE}_{7,2}=46 \text { percent } \\
& Q_{7,10}=0.156 \mathrm{~A}^{1.04} \mathrm{~K}^{0.144} \mathrm{Bf}^{0.881} \\
& \mathrm{SE}_{7,10}=48 \text { percent } \\
& \mathrm{Q}_{7,10}=0.541 \mathrm{~A}^{0.986} \mathrm{Bf}^{1.00} \\
& \mathrm{SE}_{7,10}=56 \text { percent }
\end{aligned}
$$

$Q_{7,2}, Q_{7,10}, A$, and $K$ are as defined for equations 1 and 2 , and

$\mathrm{Bf}$ is the base-flow index, in cubic feet per second per square mile.

Equations 3 and 5 are the better equations because they have lower standard error of estimates. Equations 4 and 6 are provided, even though they have a higher standard error, because they are easier to apply and might be used for some purposes.

Equations 3, 4, 5, and 6 should provide estimates of $Q_{7,2}$ and 27,10 at approximately the SE indicated for sites where base-flow discharge measurements have been made during low base-flow conditions. In addition, for sites without streamflow data and not on small tributaries, equations 3, 4, 5, and 6 should provide more reliable estimates than equations 1 and 2 for the following conditions:

1. For ungaged sites that are located in an area where the degree of uniformity among $B f$ values is high (approximately \pm 0.15 ), as shown on plate 2 . 
2. For ungaged sites that are located within the indicated subbasins on plate 2 .

Equations 3 through 6 are applicable for use at sites with drainage areas less than $184 \mathrm{mi}^{2}$.

\section{Verification of regression equations that use base-flow index}

To test the validity of equations 3 and 5 for other flow conditions and time periods, the following comparison was performed using streamflow data collected at low-flow partial-record stations. Periods selected for analyses were: a low base-flow period (flow durations greater than 80 percent); a medium base-flow period (flow durations between 60 and 80 percent); and during a high base-flow period (flow durations between 40 and 60 percent). Values of Bf were obtained as outlined previously. Substituting these new values of Bf into equations 3 and 5, estimates of $Q_{7,2}$ and $Q_{7,10}$ were determined for low-flow partial-record stations. When compared to the 87,2 and 87,10 values listed in table 1 the following SE's were determined for the estimated low-flow characteristies.

\begin{tabular}{lccccc}
\hline $\begin{array}{c}\text { Regression } \\
\text { analysis } \\
\text { equations }\end{array}$ & $\begin{array}{c}\text { SE from } \\
\text { regression } \\
\text { analysis }\end{array}$ & $\begin{array}{c}\text { Low } \\
\text { base flow }\end{array}$ & $\begin{array}{c}\text { Medium } \\
\text { base flow }\end{array}$ & $\begin{array}{c}\text { High } \\
\text { base flow }\end{array}$ & $\begin{array}{c}\text { for determine Bf } \\
\text { fonditions } \\
\text { three }\end{array}$ \\
\hline Equation 3 & 36 percent & 17 percent & 59 percent & 96 percent & 57 percent \\
Equation 5 & 48 percent & 33 percent & 72 percent & 130 percent & 78 percent \\
\hline
\end{tabular}

As illustrated, equations 3 and 5 provide satisfactory results for low base-flow conditions. For medium and high base-flow conditions equations 3 and 5 provide results that are significantly higher than the SE expected from the regression analysis.

\section{APPLICATION OF ESTIMATING PROCEDURES}

\section{Sites without streamflow data} follows :

Computation of low-flow characteristics at an ungaged site may be made as

1. If the conditions listed on pages 18 and 19 are met, use equations 3 and 5 (page 18) to determine the low-flow characteristics at ungaged sites.

2. Compute drainage area as indicated on page 13.

3. Compute hydraulic conductivity as indicated on page 16 . 
4. Determine base-flow index from plate 2 .

5. Substitute these values into equations 3 and 5 and solve for the lowflow characteristics.

6. If the conditions outlined on pages 18 and 19 cannot be met, use equations 1 and 2 (page 17) to determine low-flow characteristics.

7. Compute the drainage area as indicated on page 13.

8. Determine drift thickness as indicated on page 16 .

9. Determine hydraulic conductivity as indicated on page $\mathbf{1 6}$.

10. Substitute drainage area, drift thickness, and hydraulic conductivity values into equations 1 and 2 and solve for the low-flow characteristics.

For ungaged sites where the degree of uniformity of base-flow index values is high, $\mathrm{Bf}$ can be determined from plate 2 and equations 3 and 5 can be used to determine the low-flow characteristics. For example, to determine the low-flow characteristics for Spirit River at a country road crossing about 3 mi upstream from the confluence with North Fork Spirit River the applicable equations are:

$$
\begin{aligned}
& Q_{7,2}=0.242 \mathrm{~A}^{0.971_{\mathrm{K}}}{ }^{0.140_{\mathrm{Bf}^{0}}} 0.711 \\
& Q_{7,10}=0.156 \mathrm{~A}^{1.04} \mathrm{~K}^{0.144} \mathrm{Bf}^{0.881}
\end{aligned}
$$

Drainage area was determined as outlined on page 13 and is $32.7 \mathrm{mi}^{2}$.

The base-flow index is determined from plate 2 and is a weighted average based on drainage area:

$$
\mathrm{Bf}=\frac{\mathrm{A}_{1} \mathrm{Bf}_{1}+\mathrm{A}_{2} \mathrm{Bf}_{2}}{\mathrm{~A}_{1}+\mathrm{A}_{2}}
$$

where: $\quad A_{1}=$ drainage area at station $05393402=22.0 \mathrm{mi}^{2}$,

$$
\mathrm{Bf}_{1}=\text { base-flow index at station } 05393402=0.14 \text {, }
$$

$\mathrm{A}_{2}=$ intervening drainage area between site of interest and station $05393402=10.7 \mathrm{mi}^{2}$,

$\mathrm{Bf}_{2}=$ base-flow index for intervening area between site of interest and station $05393402=0.08$.

$$
\begin{aligned}
& \mathrm{Bf}=\frac{\mathrm{A}_{1} \mathrm{Bf}_{1}+\mathrm{A}_{2} \mathrm{Bf}_{2}}{\mathrm{~A}_{1}+\mathrm{A}_{2}} \\
& \mathrm{Bf}=\frac{22.0(0.14)+10.7(0.08)}{22.0+10.7}
\end{aligned}
$$




$$
\begin{aligned}
& B f=\frac{3.08+0.86}{32.7}=\frac{3.94}{32.7} \\
& B f=0.12
\end{aligned}
$$

The following calculations were made to determine values of hydraulic conductivity from figure 7 .

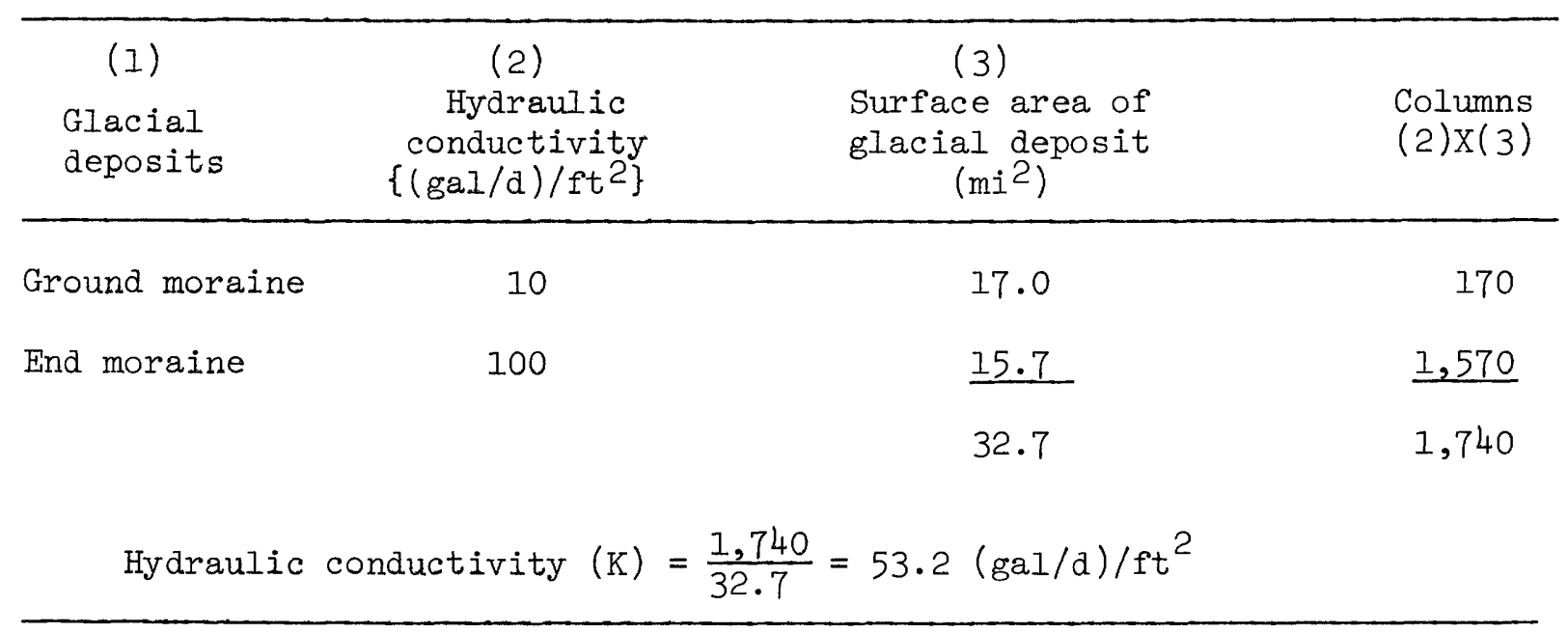

Substituting these values into their respective equations:

$$
\begin{aligned}
Q_{7,2} & =0.242 \mathrm{~A}^{0.971_{\mathrm{K}} 0.140_{\mathrm{Bf}}^{0.711}} \\
& =0.242(32.7)^{0.971}(53.2)^{0.140}(0.12)^{0.711} \\
& =0.242(29.6)(1.74)(0.22) \\
& =2.7 \mathrm{ft}^{3} / \mathrm{s} \\
Q_{7, i 0} & =0.156 \mathrm{~A}^{1.04} \mathrm{~K}^{0.144} \mathrm{Bf}^{0.881} \\
& =0.156(32.7)^{1.04}(53.2)^{0.144}(0.12)^{0.881} \\
& =0.156(37.6)(1.77)(0.15) \\
& =1.6 \mathrm{ft}^{3 / \mathrm{s}}
\end{aligned}
$$

Low-flow characteristics for ungaged sites in which conditions on pages 18 and 19 are not met can be determined by regression equations 1 and 2 . The lowflow characteristics of Indian Creek at confluence with Stone Lake are determined to illustrate the application of equations 1 and 2 .

The applicable equations for an ungaged area are: 


$$
\begin{aligned}
& Q_{7,2}=1.82 \times 10^{-3} \mathrm{~A}^{0.782} \mathrm{H}^{0.804} \mathrm{~K}^{0.254} \\
& Q_{7,10}=4.94 \times 10^{-4} \mathrm{~A} 0.817_{\mathrm{H}} 0.909_{\mathrm{K}} 0.295
\end{aligned}
$$

The drainage area for this site as outlined on page 13 is $12.2 \mathrm{mi}^{2}$. The average drift thickness for the Indian Creek drainage area from figure 7 is about $125 \mathrm{ft}$. The entire drainage area of Indian Creek was determined from figure 7 to be glacial outwash, which has a hydraulic conductivity of $2,500(\mathrm{gal} / \mathrm{d}) / \mathrm{ft} 2$. Substituting these values into the respective equation:

$$
\begin{aligned}
Q_{7,2} & =1.82 \times 10^{-3} \mathrm{~A}{ }^{0.782} \mathrm{H}^{0.804} \mathrm{~K}^{0.254} \\
& =\left(1.82 \times 10^{-3}\right)(12.2)^{0.782}(125)^{0.804}(2,500)^{0.254} \\
& =\left(1.82 \times 10^{-3}\right)(7.07)(48.5)(7.30) \\
& =4.6 \mathrm{ft}^{3} / \mathrm{s} \\
Q_{7,10} & =4.94 \times 10^{-4} \mathrm{~A} 0.81 \mathrm{H}^{0.909_{\mathrm{K}} 0.295} \\
& =\left(4.94 \times 10^{-4}\right)(12.2)^{0.817}(125)^{0.909}(2,500)^{0.295} \\
& =\left(4.94 \times 10^{-4}\right)(7.72)(80.6)(10.1) \\
& =3.1 \mathrm{ft}^{3} / \mathrm{s}
\end{aligned}
$$

\section{Sites with minimum streamflow data}

The following is an example of how to determine low-flow characteristics at sites where minimum streamflow data are available or where a streamflow measurement is required. A streamflow measurement should be obtained at sites if there isn't a high degree of uniformity among $B f$ values, as shown on plate 2, and a more accurate estimate is required than that associated with equations 1 and 2 .

1. Use equations 3 and 5 listed on page 18 to determine the low-flow characteristics.

2. Obtain a streamflow measurement at the required site. Check base-flow conditions to make sure measurement will be or was made during low base-flow conditions (discharge is lower than the 80 percent flowduration discharge at nearby gaging stations).

3. If the streamflow measurements are made during low base-flow conditions, the $\mathrm{Bf}$ should be determined as outlined on pages 14 and 16 .

4. Compute the other basin characteristics, drainage area and hydraulic conductivity, used in the equation as outlined on pages 13 and 16.

5. Substitute values determined in steps 3 and 4 into equations 3 and 5 . 
Low-flow characteristics are presented for sites in table 1 that meet criteria outlined in 2 above. As an example of how to determine low-flow characteristics at sites where streamflow measurements will be obtained by some other source than this report, Newbold Creek near Rhinelander (05391055) is used to illustrate the procedure.

The applicable equations are:

$$
\begin{aligned}
& Q_{7,2}=0.242 \mathrm{~A}^{0.971_{\mathrm{K}}}{ }^{0.140_{\mathrm{Bf}}} 0.711 \\
& \mathrm{Q}_{7,10}=0.156 \mathrm{~A}^{1.04} \mathrm{~K}^{0.144} \mathrm{Bf}^{0.881}
\end{aligned}
$$

Drainage area (A) obtained from table 1 , page 34 , is $10.9 \mathrm{mi}^{2}$.

The hydraulic conductivity and drift thickness are determined from the glacial geology map (fig. 7). The Newbold Creek drainage basin is entirely outwash with a $K=2,500(\mathrm{gal} / \mathrm{d}) / \mathrm{ft}^{2}$.

$$
B f=\frac{Q_{m} Q_{90}}{A Q_{r}}
$$

where: $Q_{m}$ is the measured discharge, $2.44 \mathrm{ft}^{3} / \mathrm{s}$, of Newbold Creek near Rhinelander on September 25, 1979;

A is the drainage area, $10.9 \mathrm{mi}^{2}$, of Newbold Creek near Rhinelander;

$\mathrm{Q}_{\mathrm{r}}$ is the recorded discharge at a nearby continuous-record gaging station. Referring to plate 1, station 05394500, Prairie River near Merrill is the closest unregulated gaging station. From "Water Resources Data for Wisconsin" (1979) the average daily discharge for September 25, 1979, was $84 \mathrm{ft} 3 / \mathrm{s}$; which is at the 80 percent flow duration point; and the

$Q_{90}$ for Prairie River near Merrill is $75 \mathrm{ft}^{3} / \mathrm{s}$, obtained from table 1 . Substituting these values in the equation:

$$
\begin{aligned}
\mathrm{Bf} & =\frac{Q_{m} Q_{90}}{A Q_{r}} \\
& =\frac{(2.44)(75)}{(10.9)(84)} \\
& =0.200
\end{aligned}
$$

The low-flow characteristics then can be determined by substituting these values in their respective equations: 


$$
\begin{aligned}
& Q_{7,2}=0.242 \mathrm{~A}^{0.971_{\mathrm{K}}} 0.140_{\mathrm{Bf}} 0.711 \\
& =(0.242)(10.9)^{0.971}(2,500)^{0.140}(0.200)^{0.711} \\
& =(0.242)(10.2)(2.99)(0.318) \\
& =2.3 \mathrm{ft}^{3} / \mathrm{s} \\
& Q_{7,10}=0.156 \mathrm{~A}^{1.04} \mathrm{~K}^{0.144} \mathrm{Bf}^{0.881} \\
& =(0.156)(10.9)^{1.04}(2,500)^{0.144}(0.200)^{0.881} \\
& =(0.156)(12.0)(3.09)(0.242) \\
& =1.4 \mathrm{ft}^{3} / \mathrm{s}
\end{aligned}
$$

\section{COMPARISON OF METHODS}

If estimates of low-flow characteristics are required at sites other than those presented in this report, the user interested in the data should evaluate the need for the low-flow information and then select a method based on following criteria. Generally the most important criteria in choosing a method are: accuracy requirements of the low-flow characteristics; time available to collect and analyze data; and cost of data collection and analyses.

Table 3 compares the methods available and provides: type of data required; number of sites where required data are available; time required to collect data; analytical method used to determine the low-flow characteristics; and standard error of estimate associated with the method. If a high degree of reliability is required of low-flow characteristics and sufficient time is available for data collection, a gaging station or low-flow partial-record station can be operated. If a lesser degree of reliability is acceptable at a site or time and money are limited, three base-flow discharge measurements can be obtained or one of the regression equations may be sufficient.

The moderately high SE's associated for all the methods, except for gaging stations and low-flow partial-record stations, reflects the large differences in low flow for streams in the upper Wisconsin River basin. This is due in part to the large number of lakes and wetlands within the basin which cause regulation of streamflow and increased evapotranspiration. For some streams it appears storage of spring runoff in lakes and wetlands may have produced high base flow while in other basins the increased evaporation from lake and wetland areas has reduced the base flow. This is illustrated by comparing the 47,10 discharge of Mud Creek (053906285) and Deerskin River (05390615), both located near Eagle River. The 27,10 of Mud Creek is $0.12(\mathrm{ft} 3 / \mathrm{s}) / \mathrm{mi} 2$ while Deerskin River is $0.32(\mathrm{ft} 3 / \mathrm{s}) / \mathrm{mi}$. Both of these streams drain glacial outwash and have extensive lake and wetland areas but have different low-flow characteristics. 


\section{SUMMARY}

Low-flow characteristics were determined for 10 gaging stations, 13 lowflow partial-record stations, and 81 miscellaneous sites in the upper Wisconsin River basin.

The method used in estimating the low-flow characteristics was dependent on the amount of discharge data available at the site. The low-flow characteristics at a gaging station with 10 or more years of record was determined by a logPearson Type III frequency analysis or plotting-position analysis. At a lowflow partial-record station (seven or more discharge measurements) or miscellaneous site (three or more discharge measurements) a graphical regression was used to determine the 47,2 and $Q_{7,10}$. At miscellaneous sites (one or two discharge measurements) and ungaged sites (no discharge measurements) multiple-regression equations were developed to determine the low-flow characteristics. The standard. error of estimate of the 7-day, 10-year low flow ( $\mathrm{SE}_{7,10}$ ) ranged from 9 to 113 percent, depending on the type of data available. The methods used to determine the standard errors are not precise and should be used as a relative guide to indicate a general level of confidence.

The multiple-regression equations developed made it possible to determine the low-flow characteristics at ungaged sites with an acceptable degree of accuracy for some purposes. Two sets of equations were determined, one for use at sites without any additional streamflow data and the other for sites with base-flow measurements. The latter equations had an $\mathrm{SE}_{7,10}$ of 48 percent compared to 113 percent for the former. The most significant characteristics in explaining the variation in low flow were drainage area, hydraulic conductivity, drift thickness, and base-flow index.

The moderately high SE's associated for all the methods, except for gaging stations and low-flow partial-record stations, reflects the large differences in low flow for streams in the upper Wisconsin River basin. This is due in part to the large number of lakes and wetlands which cause regulation and evapotranspiration that is difficult to quantify in multiple-regression analyses.

\section{REFERENCES}

Benson, M. A., 1962, Factors influencing the occurrence of floods in a humid region of diverse terrain: U.S. Geological Survey Water-Supply Paper $1580-\mathrm{B}, 64 \mathrm{p}$.

1964, Factors affecting the occurrence of floods in the Southwest: U.S. Geological Survey Water-Supply Paper 1580-D, 72 p.

Dutton, C. E., and Bradley, R. E., 1970, Lithologic, geophysical, and mineral community maps of Precambrian rocks in Wisconsin: U.S. Geological Survey Miscellaneous Investigations Series I-63I.

Gebert, W. A., 1971, Low-flow frequency of Wisconsin streams: U.S. Geological Survey Hydrologic Investigations Atlas HA-390. 
Hardison, C. H., 1969, Accuracy of streamflow characteristics, in Geological Survey Research 1969: U.S. Geological Survey Professional Paper 650-D, p. D210-D214.

Hardison, C. H., and Moss, M. E., 1972, Accuracy of low-flow characteristics estimated by correlation of base-flow measurements: U.S. Geological Survey Water-Supply Paper 1542-B, 55 p.

Holmstrom, B. K., 1972, Drainage-area data for Wisconsin streams: U.S. Geological Survey open-file report.

1979, Lowflow characteristics of Wisconsin streams at sewagetreatment plants and industrial plants: U.S. Geological Survey Water-Resources Investigations $7931,123 \mathrm{p}$.

Oakes, E. L., and Cotter, R. D., 1975, Water resources of Wisconsin--upper Wisconsin River basin: U.S. Geological Survey Hydrologic Investigations Atlas HA-536.

Riggs, H. C., 1972, Low-flow investigations: U.S. Geological Survey Techniques of Water-Resources Investigations, Book 4, Chapter BI, $18 \mathrm{p}$.

Thomas, D. M., and Benson, M. A., 1970, Generalization of streamflow characteristics from drainage-basin characteristics: U.S. Geological Survey WaterSupply Paper 1975, $55 \mathrm{p}$.

Thwaites, F. T., 1956, Glacial features of Wisconsin: Wisconsin Geological and Natural History Survey open-file map.

U.S. Geological Survey, 1980, Water resources data for Wisconsin, 1979: U.S. Geological Survey Water-Data Report WI-79-1 (in press).

Weeks, E. P., and Stangland, H. G., 1971, Effects of irrigation on streamflow in the central sand plain of Wisconsin: U.S. Geological Survey open-file report, $113 \mathrm{p}$.

Wisconsin Crop Reporting Service, 1961, Wisconsin climatological data: Madison, Wisconsin Department of Agriculture, $166 \mathrm{p}$.

Wisconsin Statistical Reporting Service, 1967, Wisconsin weather: Madison, Wisconsin Statistical Reporting Service, $31 \mathrm{p}$.

1970, Snow and frost in Wisconsin: Madison, Wisconsin Statistical Reporting Service, $28 \mathrm{p}$. 
Table 1.--Low-flow characteristics for sites in the upper Wisconsin River basin

05390102 Wisconsin River at Lac Vieux Desert outlet near Land 0'Lakes, Wis.

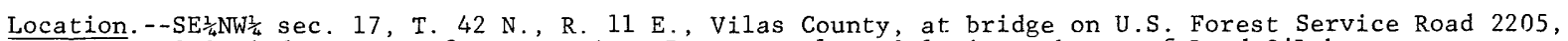
$0.3 \mathrm{mi}$ downstream from Lac Vieux Desert outlet, $3.1 \mathrm{mi}$ southeast of Land 0 'Lakes.

Drainage area. $--34.5 \mathrm{mi}^{2}$. Tributary to.--Mississippi River.

Type of site.--Miscellaneous site.

Discharge measurements.--0ct. $12,1971,65.29 \mathrm{ft}^{3} / \mathrm{s} ; \mathrm{Sept} .26,1979,52.6 \mathrm{ft}^{3} / \mathrm{s}$.

05390110 Wisconsin River near Land 0'Lakes, Wis.

Location. - $-\mathrm{NE} \frac{1}{4} \mathrm{NE} \frac{1}{4} \mathrm{sec} .11$, T. $42 \mathrm{~N}$., R. 10 E., Vilas Count.y, at bridge on State Highway $32,1.5 \mathrm{mi}$ south of Land 0 'Lakes.

Drainage area. $--47.4 \mathrm{mi}^{2}$. Tributary to. --Mississippi River.

Type of site.--Miscellaneous site.

Discharge measurements.--Oct. $11,1971,72.43 \mathrm{ft}^{3} / \mathrm{s} ;$ Sept. $25,1979,61.9 \mathrm{ft}^{3} / \mathrm{s}$.

05390111 Wisconsin River tribuary at Land O'Lakes, Wis.

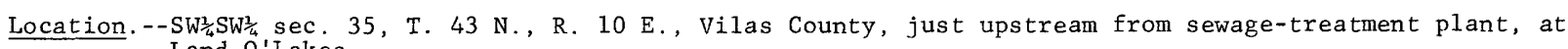
Land 0 'Lakes.

Drainage area. $--0.44 \mathrm{mi}^{2}$. Tributary to. - -Wisconsin River.

Type of site.--Miscellaneous site.

Minimum discharge measured.--No flow observed on June 23, 1974, July 15, 1975, and August 1, 1975.

Low-flow frequency. $-Q_{7,2}=0 \mathrm{ft}^{3} / \mathrm{s}, Q_{7,10}=0 \mathrm{ft}^{3} / \mathrm{s}$.

Basis of estimate.--No flow observed on three occasions.

Accuracy. --Not applicable.

05390115 Portage Creek near Land O'Lakes, Wis.

Location. - $-\mathrm{NW}^{\frac{1}{4}} \mathrm{NW} \frac{1}{4} \mathrm{sec} .16$, T. $42 \mathrm{~N} .$, R. $10 \mathrm{E}$., Vilas County, at bridge on town road, $3.2 \mathrm{mi}$ south of Land 0 'Lakes.

Drainage area. $--26.0 \mathrm{mi}^{2}$. Tributary to. --Wisconsin River.

Type of site.--Miscellaneous site.

Discharge measurements.--0ct. $11,1971,20.85 \mathrm{ft}^{3} / \mathrm{s} ;$ Sept. $25,1979,15.8 \mathrm{ft}^{3} / \mathrm{s}$.

Low-flow frequency. $-Q_{7,2}=9.5 \mathrm{ft}^{3} / \mathrm{s}, Q_{7,10}=6.9 \mathrm{ft}^{3} / \mathrm{s}$.

Basis of estimate. --Used multiple-regression equations 3 and 5 .

Accuracy. $-\mathrm{SE}_{7,2}=36$ percent, $\mathrm{SE}_{7,10}=48$ percent.

05390119 Haymeadow Creek near Land O'Lakes, Wis .

Location. - - SW $\frac{1}{4} \mathrm{SW} \frac{1}{4} \mathrm{sec} .19$, T. $41 \mathrm{~N}$, R. $10 \mathrm{E}$, Vilas County, at town road, 4.5 mi south of Land 0 'Lakes.

Drainage area. $--3.82 \mathrm{mi}^{2}$. Tributary to. - -Wisconsin River.

Type of site.--Miscellaneous site.

Discharge measurement.--Sept. $25,1979,2.34 \mathrm{ft}^{3} / \mathrm{s}$.

Low-flow frequency. $-Q_{7,2}=0.69 \mathrm{ft}^{3} / \mathrm{s}, 0.7,10=0.43 \mathrm{ft}^{3} / \mathrm{s}$.

Basis of estimate. - Used multiple-regression equations 3 and 5 .

Accuracy.--SE $7,2=36$ percent, $\mathrm{SE}_{7,10}=48$ percent. 
05390120 Haymeadow Creek near Land O'Lakes, Wis.

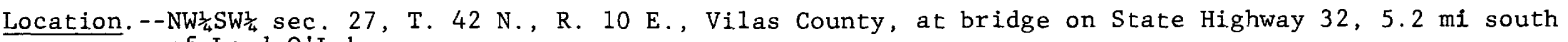
of Land 0 'Lakes.

Drainage area. $--10.2 \mathrm{mi}^{2}$. Tributary to.--Wisconsin River.

Type of site.--Miscellaneous site.

Discharge measurements.--June $28,1971,8.18 \mathrm{ft}^{3} / \mathrm{s} ;$ Oct. $11,1971,15.79 \mathrm{ft}^{3} / \mathrm{s}$.

05390130 Tamarack Creek near Conover, Wis.

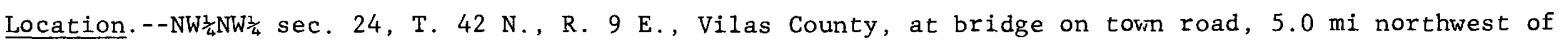
Conover.

Drainage area. $--9.62 \mathrm{mi}^{2}$. Tributary to.--Wisconsin River.

Type of site.--Miscellaneous site.

Discharge measurements.--0ct. 11, 1971, $10.3 \mathrm{ft}^{3} / \mathrm{s} ;$ Sept. $25,1979,7.82 \mathrm{ft}^{3} / \mathrm{s}$.

Low-flow frequency. $--Q_{7,2}=2.8 \mathrm{ft}^{3} / \mathrm{s}, Q_{7,10}=2.0 \mathrm{ft}^{3} / \mathrm{s}$.

Basis of estimate.--Used multiple-regression equations 3 and 5 .

Accuracy. $--\mathrm{SE}_{7,2}=36$ percent, $\mathrm{SE}_{7,10}=48$ percent.

05390140 Muskrat Creek at Conover, Wis.

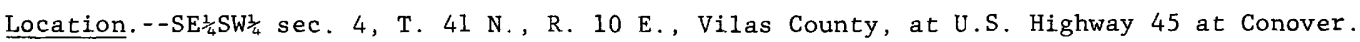

Drainage area. $-10.2 \mathrm{mi}^{2}$. Tributary to.--Wisconsin River.

Type of site.--Low-flow partial-record station.

Minimum discharge measured-- $-2.26 \mathrm{ft}^{3} / \mathrm{s}$, Sept. 15, 1976.

Low-flow frequency. $-Q_{7,2}=2.9 \mathrm{ft}^{3} / \mathrm{s}, Q_{7,10}=2.0 \mathrm{ft}^{3} / \mathrm{s}$.

Basis of estimate.--Graphical regression with Brule River near Florence using 13 discharge measurements made during the period 1968-79.

Accuracy. $--\mathrm{SE}_{7,2}=14$ percent, $\mathrm{SE}_{7,10}=24$ percent.

05390149 Military Creek at Phelps, Wis.

Location. $--\mathrm{SE}_{\frac{1}{4}} \mathrm{SW}_{\frac{1}{4}} \mathrm{sec} .35$, T. 42 N., R. 11 E., Vilas County, on County Trunk E, at Phelps.

Drainage area. $--11.6 \mathrm{mi}^{2}$. Tributary to.--Wisconsin River

Type of site.--Miscellaneous site.

Discharge measurement.--Sept. $26,1979,6.81 \mathrm{ft}^{3} / \mathrm{s}$.

Low-flow frequency. $-Q_{7,2}=3.7 \mathrm{ft}^{3} / \mathrm{s}, Q_{7,10}=2.5 \mathrm{ft}^{3} / \mathrm{s}$.

Basis of estimate.--Used multiple-regression equations 3 and 5 .

Accuracy. $-\mathrm{SE}_{7,2}=36$ percent, $\mathrm{SE}_{7,10}=48$ percent.

05390170 Pioneer Creek at Conover, Wis .

Location. - $-\mathrm{NW}_{\frac{1}{4}} \mathrm{NW}^{\frac{1}{4}} \mathrm{sec} .9, \mathrm{~T}, 41 \mathrm{~N}$, , R. $10 \mathrm{E}$, Vilas County, at bridge on State Highway $32,0.1 \mathrm{mi}$ south
of Conover.

Drainage area. $--42.0 \mathrm{mi}^{2}$. Tributary to. - Wisconsin River.

Type of site.--Miscellaneous site.

Discharge measurements.--June 28, 1971, $16.4 \mathrm{ft}^{3} / \mathrm{s} ;$ Oct. $11,1971,85.6 \mathrm{ft}{ }^{3} / \mathrm{s} ;$ Sept. $25,1979,26.2 \mathrm{ft}^{3} / \mathrm{s}$. Low-flow frequency. $-Q_{7,2}=14 \mathrm{ft}^{3} / \mathrm{s}, Q_{7,10}=11 \mathrm{ft}^{3} / \mathrm{s}$.

Basis of estimate.--Graphical regression with Brule River near Florence using 3 discharge measurements made during the period 1971-79.

Accuracy. $--\mathrm{SE}_{7,2}=28$ percent, $\mathrm{SE}_{7,10}=38$ percent (basin average). 


\section{Wisconsin River at Conover, Wis.}

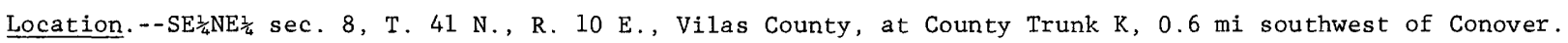
Drainage area. $--177 \mathrm{mi}^{2}$. Tributary to.--Mississippi River.

Type of site.--Gaging station.

Period of record.--October 1966 to September 1971.

Average discharge. -5 years, $175 \mathrm{ft}^{3} / \mathrm{s}$.

Extremes.--Maximum discharge $532 \mathrm{ft}^{3} / \mathrm{s}$, Apri1 13, 1971; minimum discharge $84 \mathrm{ft}^{3} / \mathrm{s}$, Aug. 17,1970 .

Low-flow frequency. - $-Q_{7,2}=84 \mathrm{ft}^{3} / \mathrm{s}, Q_{7,10}=68 \mathrm{ft}^{3} / \mathrm{s}$. Basis of estimate.--Graphical regression with Brule River near Florence using 20 discharge measurements made
during the period 1966-79.

Accuracy.- $-\mathrm{SE}_{7,2}=14$ percent, $\mathrm{SE}_{7,10}=14$ percent.

05390195 Buckatabon Creek near Star Lake, Wis.

Location.-- $-\mathrm{SW}_{\frac{1}{4}} \mathrm{NW}_{\frac{1}{4}} \mathrm{sec} .22, \mathrm{~T} .40 \mathrm{~N}$, R. 9 E., Vilas County, on town road, $5.3 \mathrm{mi}$ east of Star Lake.

Drainage area. $--8.78 \mathrm{mi}^{2}$.

Tributary to. --Wisconsin River.

Type of site.--Miscellaneous site.

Discharge measurement.--Sept. $25,1979,6.21 \mathrm{ft}^{3} / \mathrm{s}$.

Low-flow frequency. $-Q_{7,2}=3.6 \mathrm{ft}^{3} / \mathrm{s}, Q_{7,10}=2.5 \mathrm{ft}^{3} / \mathrm{s}$.

Basis of estimate.--Used multiple-regression equations 3 and 5 .

Accuracy.- $-\mathrm{SE}_{7,2}=36$ percent, $\mathrm{SE}_{7,10}=48$ percent.

05390221 Sucker Creek near Eagle River, Wis.

Location.- - $\frac{\mathrm{N}}{2} \mathrm{sec}$. 4, T. $40 \mathrm{~N} ., \mathrm{R} .10 \mathrm{E}$. Vilas County, on U.S. Highway 45, at outlet of Lake of the Hills, $4.4 \mathrm{mi}$ north of Eagle River.

Drainage area. $--2.11 \mathrm{mi}^{2}$.

Tributary to. --Wisconsin River.

Type of site.--Miscellaneous site.

Discharge measurement.--Sept. $25,1979,3.90 \mathrm{ft}^{3} / \mathrm{s}$.

Low-flow frequency. $-Q_{7,2}=1.8 \mathrm{ft}^{3} / \mathrm{s}, 0.7,10=1.4 \mathrm{ft}^{3} / \mathrm{s}$.

Basis of estimate.--Used multiple-regression equations 3 and 5 .

Accuracy.-- $\mathrm{SE}_{7,2}=36$ percent, $\mathrm{SE}_{7,10}=48$ percent.

05390240 Fourmile Creek near Three Lakes, Wis.

Location.-- $\mathrm{NW}_{\frac{1}{4}} \mathrm{NE}^{\frac{1}{4}} \mathrm{sec} .26$, T. $39 \mathrm{~N}$, R. $11 \mathrm{E}$., Oneida County, at U.S. Forest Service Road $3742,5.5 \mathrm{mi}$

Drainage area. - $10.3 \mathrm{mi}^{2}$.

Tributary to. --Eagle River.

Type of site.--Miscellaneous site.

Discharge measurement.--Sept. $27,1979,2.90 \mathrm{ft}^{3} / \mathrm{s}$.

Low-flow frequency. $-Q_{7,2}=2.3 \mathrm{ft}^{3} / \mathrm{s}, Q_{7,10}=1.4 \mathrm{ft}^{3} / \mathrm{s}$.

Basis of estimate.--Used multiple-regression equations 3 and 5 .

Accuracy. $--\mathrm{SE}_{7,2}=36$ percent, $\mathrm{SE}_{7,10}=48$ percent. 
05390242 Townline Creek near Three Lakes, Wis.

Location. - $-\mathrm{SE} \frac{3}{4} \mathrm{NE} \frac{3}{4} \mathrm{sec} .1, \mathrm{~T} .38 \mathrm{~N}$, , R. $10 \mathrm{E}$. , Oneida County, at U.S. Highway $45,0.8 \mathrm{mi}$ north of Three Lakes. Drainage area. $-3.29 \mathrm{mi}^{2}$. Tributary to.--Eagle River.

Type of site.--Miscellaneous site.

Minimum discharge measured.--No flow observed on July 13, 1972; August 30, 1973; July 15, 1975; and August 1, 1975 .

Low-flow frequency. $-\mathrm{Q}_{7,2}=0 \mathrm{ft}^{3} / \mathrm{s}, Q_{7,10}=0 \mathrm{ft}^{3} / \mathrm{s}$.

Basis of estimate.--No flow observed on four occasions.

Accuracy. - Not applicable.

05390246 Ninemile Creek near Eagle River, Wis.

Location. - $-\mathrm{NW} \frac{1}{4} \mathrm{SW} \frac{1}{4}$ sec. 36, T. 40 N., R. 11 E., Vilas County, on Military Road, 8.5 mi east of Eagle River. Drainage area. $--7,44 \mathrm{mi}^{2}$. Tributary to.--Eagle River.

Type of site.--Miscellaneous site.

Discharge measurement.--Sept. $26,1979,5.31 \mathrm{ft}^{3} / \mathrm{s}$.

Low-flow frequency. $-Q_{7,2}=3.2 \mathrm{ft}^{3} / \mathrm{s}, 0_{7,10}=2.2 \mathrm{ft}^{3} / \mathrm{s}$.

Basis of estimate.--Used multiple-regression equations 3 and 5 .

Accuracy. $--\mathrm{SE}_{7,2}=36$ percent, $\mathrm{SE}_{7,10}=48$ percent.

$05 \$ 90248$ Hay Meadow Creek near Three Lakes, Wis.

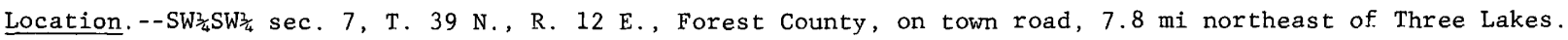
Drainage area. $--6.55 \mathrm{mi}^{2}$. Tributary to.--Sevenmile Creek.

Type of site.--Miscellaneous site.

Discharge measurement.--Sept. $26,1979,3.76 \mathrm{ft}^{3} / \mathrm{s}$.

Low-flow frequency. $-Q_{7,2}=2.4 \mathrm{ft}^{3} / \mathrm{s}, Q_{7,10}=1.6 \mathrm{ft}^{3} / \mathrm{s}$.

Basis of estimate.--Used multiple-regression equations 3 and 5 .

Accuracy. $--\mathrm{SE}_{7,2}=36$ percent, $\mathrm{SE}_{7,10}=48$ percent.

05390355 Spring Meadow Creek near Eagle River, Wis.

Location. - $-\mathrm{SE} \frac{1}{4} \mathrm{SE}_{\frac{1}{4}} \mathrm{sec} .29$, T. 40 N., R. 11 E., Vilas County, on Ninemile Road, 5.7 mi east of Eagle River

Drainage area. $--4.95 \mathrm{mi}^{2}$. Tributary to.--Eagle River.

Type of site.--Miscellaneous site.

Discharge measurement.--Sept. $26,1979,4.91 \mathrm{ft}^{3} / \mathrm{s}$.

Low-flow frequency. $-Q_{7,2}=2.7 \mathrm{ft}^{3} / \mathrm{s}, Q_{7,10}=1.9 \mathrm{ft}^{3} / \mathrm{s}$.

Basis of estimate.--Used multiple-regression equations 3 and 5 .

Accuracy, $--\mathrm{SE}_{7,2}=36$ percent, $\mathrm{SE}_{7,10}=48$ percent. 
05390410 Deerskin River near Phelps, Wis.

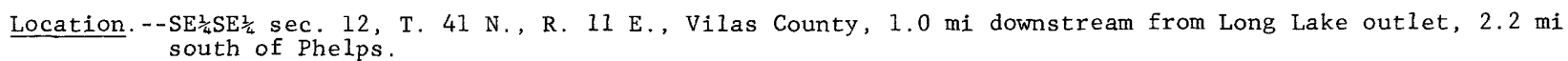
Drainage area. $--23.4 \mathrm{mi}^{2}$. Tributary to. --Eagle River.

Type of site.--Miscellaneous site.

Discharge measurements.--Oct. 12, 1971, $42.2 \mathrm{ft}^{3} / \mathrm{s} ;$ Sept. $26,1979,10.5 \mathrm{ft} / \mathrm{s}$.

Low-flow frequency. $-Q_{7,2}=6.3 \mathrm{ft}^{3} / \mathrm{s}, Q_{7,10}=4.3 \mathrm{ft}^{3} / \mathrm{s}$.

Basis of estimate.--Used multiple-regression equations 3 and 5 .

Accuracy. $--\mathrm{SE}_{7,2}=36$ percent, $\mathrm{SE}_{7,10}=48$ percent.

05390450 Deerskin River near Eagle River, Wis.

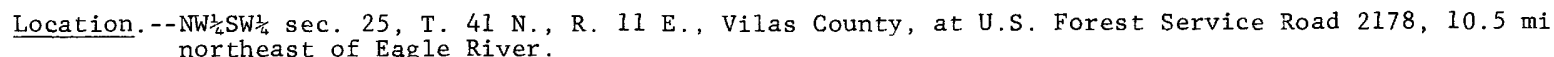

Drainage area. $--32.4 \mathrm{nni}^{2}$.

Tributary to.--Eagle River.

Type of site.--Low-flow partial-record station.

Minimum discharge measured. $--15.2 \mathrm{ft}^{3} / \mathrm{s}$, Aug. 12, 1970.

Low-flow frequency. $-Q_{7,2}=16 \mathrm{ft}^{3} / \mathrm{s}, Q_{7,10}=13 \mathrm{ft}^{3} / \mathrm{s}$.

Basis of estimate.--Graphical regression with Brule River near Florence using 14 discharge measurements made during the period 1968-79.

Accuracy. $-\mathrm{SE}_{7,2}=9$ percent, $\mathrm{SE}_{7,10}=12$ percent.

05390615 Deerskin River near Eagle River, Wis.

Location. - $-\mathrm{SE}_{\frac{1}{4}} \mathrm{NE}_{\frac{1}{4}} \mathrm{sec} .13, \mathrm{~T} .40 \mathrm{~N}$, R. $10 \mathrm{E}$., Vilas County, at bridge on town road, $4.3 \mathrm{mi}$ northeast of Eagle River.

Drainage area. $--65.3 \mathrm{mi}^{2}$. Tributary to.--Eagle River.

Type of site.-Miscellaneous site.

Discharge measurements.--Oct. $12,1971,98.9 \mathrm{ft}^{3} / \mathrm{s} ;$ Sept. $26,1979,50.2 \mathrm{ft} / \mathrm{s}$.

Low-flow frequency. $-Q_{7,2}=26 \mathrm{ft}^{3} / \mathrm{s}, Q_{7,10}=21 \mathrm{ft}^{3} / \mathrm{s}$.

Basis of estimate.--Used multiple-regression equations 3 and 5 .

Accuracy. $-\mathrm{SE}_{7,2}=36$ percent, $\mathrm{SE}_{7,10}=48$ percent.

05390619 Rice Creek near Eagle River, Wis.

Location.-- $\mathrm{SW}_{\frac{1}{4}} \mathrm{SE}_{\frac{1}{4}} \mathrm{sec} .14, \mathrm{~T} .40 \mathrm{~N}$, , R. 9 E., Vilas County, at bridge on County Trunk G, $4.1 \mathrm{mi}$ northwest

Drainage area. $-26.5 \mathrm{mi}^{2}$

Drainage area. $-26.5 \mathrm{mi}^{2}$. Tributary to.--Wisconsin River.

Type of site.--Miscellaneous site.

Discharge measurements.--June 28, 1971, 24.4 $\mathrm{ft}^{3} / \mathrm{s} ;$ Oct. $11,1971,37.4 \mathrm{ft}^{3} / \mathrm{s} ; \mathrm{Sept} .24,1979,14.5 \mathrm{ft} / \mathrm{s}$. Low-flow frequency. $-Q_{7,2}=10 \mathrm{ft}^{3} / \mathrm{s}, Q_{7,10}=7.3 \mathrm{ft}^{3} / \mathrm{s}$.

Basis of estimate.--Graphical regression with Brule River near Florence using 3 discharge measurements made during the period 1971-79.

Accuracy. $--\mathrm{SE}_{7,2}=28$ percent, $\mathrm{SE}_{7,10}=38$ percent (basin average). 
053906285 Mud Creek near Eagle River, Wis.

Location. - -NW $\frac{1}{4} \mathrm{SW} \frac{1}{4} \mathrm{sec} .33$, T. $40 \mathrm{~N} .$, R. $10 \mathrm{E}$, Vilas County, on town road, 0.7 mi south of Eagle River. Drainage area. $--40.8 \mathrm{mi}^{2}$. Tributary to.--Wisconsin River.

Type of site.--Miscellaneous site.

Discharge measurement.--Sept. 27, 1979, $9.62 \mathrm{ft}^{3} / \mathrm{s}$.

Low-flow frequency. $-Q_{7,2}=7.8 \mathrm{ft}^{3} / \mathrm{s}, Q_{7,10}=5.0 \mathrm{ft}^{3} / \mathrm{s}$.

Basis of estimate.--Used multiple-regression equations 3 and 5 .

Accuracy. $--\mathrm{SE}_{7,2}=36$ percent, $\mathrm{SE}_{7,10}=48$ percent.

05390720 Aurora Creek near Boulder Junction, Wis .

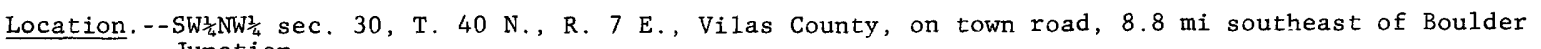
Junction.

Drainage area. $--5.73 \mathrm{mi}^{2}$. Tributary to. --P1um Creek.

Type of site.--Miscellaneous site.

Discharge measurement.--Sept. $24,1979,5.74 \mathrm{ft}^{3} / \mathrm{s}$.

Low-flow frequency. $-Q_{7,2}=3.1 \mathrm{ft}^{3} / \mathrm{s}, Q_{7,10}=2.2 \mathrm{ft}^{3} / \mathrm{s}$.

Basis of estimate.--Used multiple-regression equations 3 and 5 .

Accuracy. $-\mathrm{SE}_{7,2}=36$ percent, $\mathrm{SE}_{7,10}=48$ percent.

05390725 Plum Creek near Sayner, Wis.

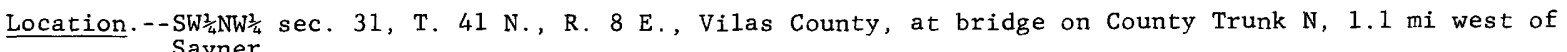
Sayner.

Drainage area. $--31.6 \mathrm{mi}^{2}$.. $\quad$ Tributary to. - $-\mathrm{St}$. Germain River.

Type of site.--Miscellaneous site.

Discharge measurements.--June $28,1971,39.5 \mathrm{ft}^{3} / \mathrm{s} ;$ Oct. $11,1971,35.6 \mathrm{ft} \mathrm{t}^{3} / \mathrm{s} ;$ Sept. $24,1979,18.2 \mathrm{ft} / \mathrm{s}$. Low-flow frequency. $-Q_{7,2}=13 \mathrm{ft}^{3} / \mathrm{s}, Q_{7,10}=9.0 \mathrm{ft}^{3} / \mathrm{s}$.

Basis of estimate.--Graphical regression with Brule River near Florence using 3 discharge measurements made during the period 1971-79.

Accuracy. $--\mathrm{SE}_{7,2}=28$ percent, $\mathrm{SE}_{7,10}=38$ percent (basin average).

05390741 Stella Creek near Sayner, Wis.

Location. $--\mathrm{SW}_{\frac{2}{4}} \mathrm{SW}_{\frac{1}{4}} \mathrm{sec} .35$, T. $41 \mathrm{~N} ., \mathrm{R} .8 \mathrm{E}$., Vilas County, at bridge on County Trunk G, $3.1 \mathrm{mi}$ east of Sayner.

Drainage area. $--6.22 \mathrm{mi}^{2}$.

Tributary to. --St. Germain River.

Type of site.--Miscellaneous site.

Discharge measurements. --June $28,1971,4.75 \mathrm{ft}^{3} / \mathrm{s} ;$ Oct. $11,1971,7.39 \mathrm{ft} / \mathrm{s} ;$ Sept. 24, 1979, 4.57 ft $3 / \mathrm{s}$. Low-flow frequency. $-Q_{7,2}=3.1 \mathrm{ft}^{3} / \mathrm{s}, Q_{7,10}=2.5 \mathrm{ft}^{3} / \mathrm{s}$.

Basis of estimate.--Graphical regression with Brule River near Florence using 3 discharge measurements made during the period 1971-79.

Accuracy.--SE $7,2=28$ percent, $S E_{7,10}=38$ percent (basin average). 
05391000 Wisconsin River at Rainbow Lake near Lake Tomahawk, Wis.

Location. - - SW $\frac{3}{4} \mathrm{SW} \frac{1}{4} \mathrm{sec} .30$, T. 39 N., R. 8 E., Oneida County, 800 ft downstream from dam at Rainbow Lake,

$2.5 \mathrm{mi}$ nor theast of Lake Tomahawk.

Drainage area. $--744 \mathrm{mi}^{2}$.

Tributary to.--Mississippi River.

Type of site.--Gaging station.

Period of record.--July 1936 to September 1977.

Average discharge. --41 years, $692 \mathrm{ft}^{3} / \mathrm{s}$.

Extremes. --Maximum discharge, 3,570 $\mathrm{ft}^{3} / \mathrm{s}$ Sept. 5, 1941; minimum discharge, $17 \mathrm{ft}{ }^{3} / \mathrm{s} 0 \mathrm{ct} .10-12,1940$; minimum daily, 35 ft $3 / \mathrm{s}$ Apr. 6,1955 .

Period Magnitude and frequency of annual low flow

of con secutive days

\begin{tabular}{rrrrrrr}
\hline & 2 & 5 & 10 & 20 & 50 & 100 \\
\cline { 2 - 7 } 7 & 209 & 159 & 140 & 128 & 117 & 110 \\
14 & 238 & 179 & 157 & 143 & 129 & 121 \\
30 & 312 & 231 & 198 & 176 & 154 & 141 \\
60 & 439 & 316 & 263 & 225 & 187 & 165 \\
90 & 494 & 370 & 317 & 278 & 239 & 216
\end{tabular}

Accuracy. $--\mathrm{SE}_{7,2}=6$ percent, $\mathrm{SE}_{7,10}=6$ percent.

Remarks.--Flow regulated by Rainbow Lake and 12 smaller reservoirs above station. Minimum flow of 17 ft $3 / \mathrm{s}$ was caused by regulation.

05391028 Horsehead Creek near Lake Tomahawk, Wis.

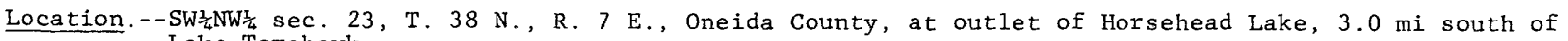
Lake Tomahawk.

Drainage area. $--5.58 \mathrm{mi}^{2}$. Tributary to. - -Wisconsin River.

Type of site.--Miscellaneous site.

Discharge measurements.--Nov. $17,1976,3.71 \mathrm{ft}^{3} / \mathrm{s} ;$ Dec. 16, 1976, 3.89 ft $3 / \mathrm{s} ; \mathrm{Sept} .25,1979,2.16 \mathrm{ft} / \mathrm{s}$. Low-flow frequency. $--Q_{7,2}=2.7 \mathrm{ft}^{3} / \mathrm{s}, Q_{7,10}=1.9 \mathrm{ft}^{3} / \mathrm{s}$.

Basis of estimate.--Used multiple-regression equations 3 and 5 .

Accuracy. $-\mathrm{SE}_{7,2}=36$ percent, $\mathrm{SE}_{7,10}=48$ percent.

05391042 Tom Doyle Creek near McNaughton, Wis.

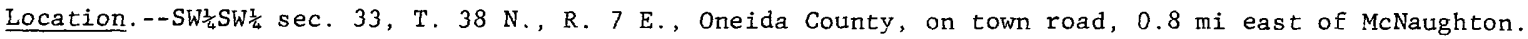
Drainage area. $--10.2 \mathrm{mi}^{2}$. Tributary to. --Wisconsin River.

Type of site.--Miscellaneous site.

Discharge measurement.--Sept. $25,1979,3.24 \mathrm{ft}^{3} / \mathrm{s}$.

Low-flow frequency. $--Q_{7,2}=2.8 \mathrm{ft}^{3} / \mathrm{s}, Q_{7,10}=1.8 \mathrm{ft}^{3} / \mathrm{s}$.

Basis of estimate.--Used multiple-regression equations 3 and 5 .

Accuracy. $--\mathrm{SE}_{7,2}=36$ percent, $\mathrm{SE}_{7,10}=48$ percent. 
Table 1.--Low-flow characteristics for sites in the upper Wisconsin River basin--Continued

05391055 Newbold Creek near Rhinelander, Wis.

Location.--
Rhinelander. Drainage area. $--10.9 \mathrm{mi}^{2}$. Tributary to. --Wisconsin River.

Type of site.--Miscellaneous site.

Discharge measurement.--Sept. 25, 1979, $2.44 \mathrm{ft}^{3} / \mathrm{s}$.

Low-flow frequency. $--_{7,2}=2.3 \mathrm{ft}^{3} / \mathrm{s}, 0,7,10=1.4 \mathrm{ft}^{3} / \mathrm{s}$.

Basis of estimate.--Used multiple-regression equations 3 and 5 .

Accuracy. $-\mathrm{SE}_{7,2}=36$ percent, $\mathrm{SE}_{7,10}=48$ percent.

05391069 Skunk Creek near Rhinelander, Wis.

Location. $-\mathrm{SE}_{\frac{1}{4}} \mathrm{NE}_{\frac{1}{4}} \mathrm{sec} .14, \mathrm{~T} .37 \mathrm{~N} .$, R. 8 E., Oneida County, on town road, 4.0 mi north of Rhinelander. Drainage area. $--7.30 \mathrm{mi}^{2}$. Tributary to. --Wisconsin River.

Type of site.--Miscellaneous site.

Discharge measurement.--Sept. 25, 1979, $0.99 \mathrm{ft}^{3} / \mathrm{s}$.

Low-flow frequency. $-\mathrm{Q}_{7,2}=1.1 \mathrm{ft}^{3} / \mathrm{s}, 0.7,10=0.58 \mathrm{ft}^{3} / \mathrm{s}$.

Basis of estimate.--Used multiple-regression equations 3 and 5 .

Accuracy.-- $\mathrm{SE}_{7,2}=36$ percent, $\mathrm{SE}_{7,10}=48$ percent.

05391085 North Pine Lake Creek near Rhinelander, Wis.

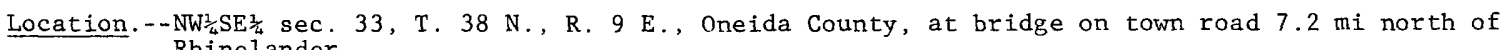
Rhinelander.

Drainage area. $--14.0 \mathrm{mi}^{2}$. Tributary to. --Wisconsin River.

Type of site.--Miscellaneous site.

Discharge measurements.--June $28,1971,6.9 \mathrm{ft}^{3} / \mathrm{s} ;$ Oct. $11,1971,27.5 \mathrm{ft}^{3} / \mathrm{s}$; Sept. $26,1979,1.93 \mathrm{ft}^{3} / \mathrm{s}$. Low-flow frequency. $-0_{7,2}=1.6 \mathrm{ft}^{3} / \mathrm{s}, 0.7,10=0.74 \mathrm{ft}^{3} / \mathrm{s}$. Basis of estimate.--Graphical regression with Prairie River near Merrill using 3 discharge measurements
made during the period 1971-79.

Accuracy.-- $\mathrm{SE}_{7,2}=28$ percent, $\mathrm{SE}_{7,10}=38$ percent (basin average).

05391088 Pine Lake Creek near Rhinelander, Wis.

Location.- $-\mathrm{NE}_{\frac{1}{4}} \mathrm{SE}_{\frac{1}{4}} \mathrm{sec} .17$, T. $37 \mathrm{~N} ., \mathrm{R} .9 \mathrm{E}$, Oneida County, at bridge on town road, $4.1 \mathrm{mi}$ north of
Rhinelander.

Drainage area. $--26.3 \mathrm{mi}^{2}$. Tributary to. - -Wisconsin River.

Type of site.--Miscellaneous site.

Discharge measurements.--June $28,1971,22.8 \mathrm{ft}^{3} / \mathrm{s} ;$ Oct. $11,1971,50.0 \mathrm{ft} / \mathrm{s} ;$ Sept. $26,1979,0.54 \mathrm{ft} / \mathrm{s}$.

Low-flow frequency. $-Q_{7,2}=1.1 \mathrm{ft}^{3} / \mathrm{s}, Q_{7,10}=0.46 \mathrm{ft}^{3} / \mathrm{s}$.

Basis of estimate.--Used multiple-regression equations 5 and 7 .

Accuracy. $-\mathrm{SE}_{7,2}=36$ percent, $\mathrm{SE}_{7,10}=48$ percent. 
Table 1.--Low-flow characteristics for sites in the upper Wisconsin River basin--Continued

05391102 Pelican River at Pelican Lake, Wis.

Location. $-\mathrm{SE}_{\frac{1}{4}} \mathrm{SW}_{\frac{1}{4}} \mathrm{sec}$. 11, T. $35 \mathrm{~N}$., R. $10 \mathrm{E}$., Oneida County, at bridge on County Trunk Q, $4.3 \mathrm{mi}$ southwest of Monico.

Drainage area. $--19.8 \mathrm{mi}^{2}$.

Tributary to. - -Wisconsin River.

Type of site.--Miscellaneous site.

Discharge measurement.--0ct. $12,1971,39.6 \mathrm{ft}^{3} / \mathrm{s}$.

05391130 Enterprise Creek at Enterprise, Wis.

Location. $--\mathrm{NE}_{\frac{1}{4}} \mathrm{NE}_{\frac{1}{4}} \mathrm{sec} .29$, T. 35 N., R. 10 E., Oneida County, at bridge on County Trunk $0,0.1 \mathrm{mi}$ west of Enterprise.

Drainage area. $--11.8 \mathrm{mi}^{2}$. Tributary to - - Pelican River.

Type of site.--Miscellaneous site.

Discharge measurements.--Oct. $12,1971,2.1 \mathrm{ft}^{3} / \mathrm{s} ;$ Sept. $25,1979,3.18 \mathrm{ft}^{3} / \mathrm{s}$.

Low-flow frequency. - $Q_{7,2}=2.5 \mathrm{ft}^{3} / \mathrm{s}, Q_{7,10}=1.5 \mathrm{ft}^{3} / \mathrm{s}$.

Basis of estimate.--Used multiple-regression equations 3 and 5 .

Accuracy. $--\mathrm{SE}_{7,2}=36$ percent, $\mathrm{SE}_{7,10}=48$ percent.

05391200 Monico Creek near Monico, Wis.

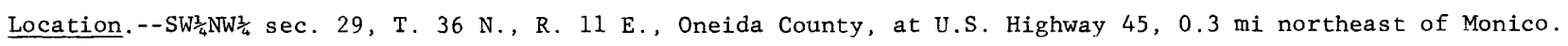

Drainage area. $--20.8 \mathrm{mi}^{2}$.

Tributary to.--Pelican River.

Type of site.--Low-flow partial-record station.

Minimum discharge measured. $-0.094 \mathrm{ft}^{3} / \mathrm{s}$, Aug. 11, 1970.

Low-flow frequency. $-Q_{7,2}=0.22 \mathrm{ft}^{3} / \mathrm{s}, Q_{7,10}=0.08 \mathrm{ft}^{3} / \mathrm{s}$.

Basis of estimate.--Graphical regression with Wolf River at Langlade using 11 measurements made during the period 1969-79.

Accuracy. $--\mathrm{SE}_{7,2}=64$ percent, $\mathrm{SE}_{7,10}=97$ percent.

05391223 Neptune Creek near Monico, Wis.

Location.-- $-\mathrm{NW}_{4}^{\frac{2}{4} \mathrm{NW} \frac{3}{4} \mathrm{sec} .}$ 27, T. $36 \mathrm{~N}$, , R. 10 E., Oneida County, on State Highway $8,3.8 \mathrm{mi}$ west of Monico.

Drainage area. $--9.04 \mathrm{mi}^{2}$.

Tributary to. --Pelican River.

Type of site.--Miscellaneous site.

Discharge measurement. --Sept. $26,1979,0.54 \mathrm{ft}^{3} / \mathrm{s}$.

Low-flow frequency. $-Q_{7,2}=0.65 \mathrm{ft}^{3} / \mathrm{s}, Q_{7,10}=0.30 \mathrm{ft}^{3} / \mathrm{s}$.

Basis of estimate.--Used multiple-regression equations 3 and 5 .

Accuracy.-- $\mathrm{SE}_{7,2}=36$ percent, $\mathrm{SE}_{7,10}=48$ percent. 
Table 1.--Low-flow characteristics for sites in the upper Wisconsin River basin--Continued

05391226 Pelican River near Rhinelander, Wis.

Location. - $-\mathrm{NE}_{\frac{1}{4}} \mathrm{NE}_{\frac{1}{4}} \mathrm{sec} .30$, T. $36 \mathrm{~N} ., \mathrm{R} .10 \mathrm{E}$, Oneida County, $0.2 \mathrm{mi}$ above Beaver Creek, at rapids, $7.1 \mathrm{mi}$ southeast of post office at Rhinelander.

Drainage area. $--101 \mathrm{mi}^{2}$. Tributary to. --Wisconsin River.

Type of site.--Gaging station.

Period of record. --January 1976 to September 1979.

Average discharge.--

Extremes.--Maximum discharge, $707 \mathrm{ft}^{3} / \mathrm{s}$ Apr. 2, 1976; minimum discharge, $0.09 \mathrm{ft}^{3} / \mathrm{s}$ Sept. 15, $16,1976$.

Low-flow frequency. $-Q_{7,2}=2.2 \mathrm{ft}^{3} / \mathrm{s}, Q_{7,10}=0.34 \mathrm{ft}^{3} / \mathrm{s}$.

Basis of estimate.--Graphical regression with Wolf River at Langlade using 12 daily discharge values recorded during period $1976-79$

Accuracy. $--\mathrm{SE}_{7,2}=140$ percent, $\mathrm{SE}_{7,10}=140$ percent.

05391250 Gudegast Creek near Rhinelander, Wis.

Location. - $-\mathrm{NE}_{\frac{1}{4}} \mathrm{SE}_{\frac{1}{4}}$ sec. 9, T. 37 N., R. 10 E., Oneida County, at town road, 9.5 mi northeast of Rhinelander. Drainage area. $--12.4 \mathrm{mi}^{2}$. Tributary to.--Pelican River.

Type of site. --Low-flow partial-record station.

Minimum discharge measured. $-0.40 \mathrm{ft}^{3} / \mathrm{s}$, Sept. 15, 1976.

Low-flow frequency. - $-Q_{7,2}=1.1 \mathrm{ft}^{3} / \mathrm{s}, 0_{7,10}=0.45 \mathrm{ft}^{3} / \mathrm{s}$.

Basis of estimate.--Graphical regression with Wolf River at Langlade using 13 discharge measurements made during the period 1969-79.

Accuracy. $--\mathrm{SE}_{7,2}=40$ percent, $\mathrm{SE}_{7,10}=52$ percent.

05391260 Gudegast Creek near Starks, Wis.

Location. - - SW $\frac{1}{4} \mathrm{NW}_{\frac{1}{4}} \mathrm{sec} .16, \mathrm{~T} .37 \mathrm{~N}$, R. $10 \mathrm{E}$, Oneida County, at town road, 3.0 mi northwest of Starks.

Drainage area. $--14.0 \mathrm{mi}^{2}$.

Tributary to.--Pelican River.

Type of site.--Miscellaneous site.

Discharge measurement. --Sept. $25,1979,5.78 \mathrm{ft}^{3} / \mathrm{s}$.

Low-flow frequency.--Unable to determine low-flow characteristics. Additional discharge measurements required.

05391265 Lost Creek near Sugar Camp, Wis.

Location. - $-\mathrm{SW}_{4} \mathrm{SE}_{4}^{\frac{1}{4}} \mathrm{sec} .26$, T. $38 \mathrm{~N} ., \mathrm{R} .9 \mathrm{E}$, Oneida County, at bridge on town road, $2.8 \mathrm{mi}$ south of Sugar Camp.

Drainage area. $--12.7 \mathrm{mi}^{2}$.

Tributary to. --Gudegast Creek.

Type of site.--Miscellaneous site.

Discharge measurements.--June $28,1971,6.19 \mathrm{ft}^{3} / \mathrm{s} ;$ Oct. $12,1971,23.0 \mathrm{ft} / \mathrm{s} ;$ Sept. $26,1979,1.60 \mathrm{ft} / \mathrm{s}$.

Low-flow frequency. $-Q_{7,2}=1.0 \mathrm{ft}^{3} / \mathrm{s}, Q_{7,10}=0.52 \mathrm{ft}^{3} / \mathrm{s}$.

Basis of estimate.--Graphical regression with Wolf River at Langlade using three discharge measurements made during the period 1971-79.

Accuracy.-- $\mathrm{SE}_{7,2}=28$ percent, $\mathrm{SE}_{7,10}=38$ percent (basin average). 
05391269 Jennie Webber Creek near Rhinelander, Wis.

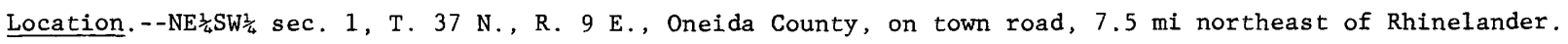
Drainage area. $--18.9 \mathrm{mi}^{2}$. Tributary to.--Gudegast Creek.

Type of site.--Miscellaneous site.

Discharge measurement.--Sept. 26, 1979, $6.0 \mathrm{ft}^{3} / \mathrm{s}$.

Low-flow frequency. $-Q_{7,2}=5.1 \mathrm{ft}^{3} / \mathrm{s}, Q_{7,10}=3.3 \mathrm{ft}^{3} / \mathrm{s}$.

Basis of estimate.--Used multiple-regression equations 3 and 5 .

Accuracy. $--\mathrm{SE}_{7,2}=36$ percent, $\mathrm{SE}_{7,10}=48$ percent.

05391278 Starks Creek near Rhinelander, Wis.

Location. - - NW $\frac{1}{4} \mathrm{NE} \frac{1}{4} \mathrm{sec} .28$, T. 37 N., R. 9 E., Oneida County, on town road, 8.0 mi northeast of Rhinelander. Drainage area. $--8.59 \mathrm{mi}^{2}$. Tributary to. --Gudegast Creek.

Type of site.--Miscellaneous site.

Discharge measurement. --Sept. 25, 1979, $6.76 \mathrm{ft}^{3} / \mathrm{s}$.

Low-flow frequency. $-Q_{7,2}=4.2 \mathrm{ft}^{3} / \mathrm{s}, Q_{7,10}=3.0 \mathrm{ft}^{3} / \mathrm{s}$.

Basis of estimate.--Used multiple-regression equations 3 and 5 .

Accuracy. $-\mathrm{SE}_{7,2}=36$ percent, $\mathrm{SE}_{7,10}=48$ percent.

\section{Twin Lakes Creek near Starks, Wis.}

Location. - - NW $\frac{3}{4} \mathrm{SW}_{4}^{\frac{1}{4}} \mathrm{sec} .35$, T. $37 \mathrm{~N} .$, R. $10 \mathrm{E}$., Oneida County, at bridge on town road, $1.3 \mathrm{mi}$ south of Starks. Drainage area. $--20.5 \mathrm{mi}^{2}$. Tributary to.--North Branch Pelican River.

Type of site.--Miscellaneous site.

Discharge measurement.--Oct. 13, 1971, $54.3 \mathrm{ft}^{3} / \mathrm{s}$.

053913035 Haymeadow Creek near Rhinelander, Wis.

Location.--SW3 $\frac{1}{4} \mathrm{NE} \frac{1}{4} \mathrm{sec} .20$, T. $36 \mathrm{~N}$, R. 9 E., Oneida County, on town road, $7.6 \mathrm{mi}$ southeast of Rhinelander. Drainage area. $--20.5 \mathrm{mi}^{2}$. Tributary to.--North Branch Pelican River.

Type of site.--Miscellaneous site. Discharge measurement.--Sept. 26, $1979,0.24 \mathrm{ft}^{3} / \mathrm{s}$.

Low-flow frequency. $-Q_{7,2}=0.49 \mathrm{ft}^{3} / \mathrm{s}, 0,7,10=0.19 \mathrm{ft}^{3} / \mathrm{s}$.

Basis of estimate. --Used multiple-regression equations 3 and 5 .

Accuracy. $--\mathrm{SE}_{7,2}=36$ percent, $\mathrm{SE}_{7,10}=48$ percent. 
05391350 Lake George Creek near Rhinelander, Wis.

Location. - - SE $\frac{1}{4}$ SW $\frac{1}{4}$ sec. 13, T. 36 N., R. 9 E., Oneida County, at bridge on U.S. Highway 8 and State Highway 47 , $5.7 \mathrm{mi}$ southeast of Rhinelander.

Drainage area. $--11.9 \mathrm{mi}^{2}$. Tributary to. --Pelican River.

Type of site.--Miscellaneous site.

Discharge measurements.--0ct. 12, 1971, $25.4 \mathrm{ft}^{3} / \mathrm{s} ;$ Sept. $26,1979,1.55 \mathrm{ft}^{3} / \mathrm{s}$.

Low-flow frequency. $-Q_{7,2}=1.8 \mathrm{ft}^{3} / \mathrm{s}, Q_{7,10}=1.0 \mathrm{ft}^{3} / \mathrm{s}$.

Basis of estimate.--Used multiple-regression equations 3 and 5 .

Accuracy. $--\mathrm{SE}_{7,2}=36$ percent, $\mathrm{SE}_{7,10}=48$ percent.

05391360 Bergman Creek near Rhinelander, Wis .

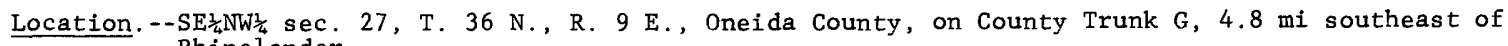
Rhinelander

Drainage area. $--5.48 \mathrm{mi}^{2}$. Tributary to.--Pelican River.

Type of site.--Miscellaneous site.

Discharge measurement. --Sept. $25,1979,1.41 \mathrm{ft}^{3} / \mathrm{s}$.

Low-flow frequency. $-Q_{7,2}=1.2 \mathrm{ft}^{3} / \mathrm{s}, Q_{7,10}=0.72 \mathrm{ft}^{3} / \mathrm{s}$.

Basis of estimate.--Used multiple-regression equations 3 and 5 .

Accuracy.-- $-\mathrm{SE}_{7,2}=36$ percent, $\mathrm{SE}_{7,10}=48$ percent.

05391450 Pelican River at Rhinelander, Wis.

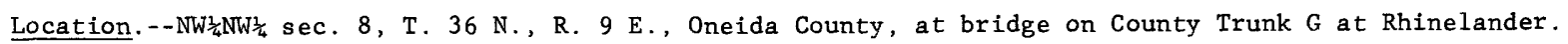
Drainage area. $--264 \mathrm{mi}^{2}$. Tributary to. - -Wisconsin River.

Type of site.--Miscellaneous site.

Minimum discharge measured. $--6.76 \mathrm{ft}^{3} / \mathrm{s}$, Sept. $16,1976$.

Low-flow frequency. $-Q_{7,2}=19 \mathrm{ft}^{3} / \mathrm{s}, Q_{7,10}=10 \mathrm{ft}^{3} / \mathrm{s}$.

Basis of estimate.--Graphical regression with Prairie River near Merrill using 9 discharge measurements made during the period 1972-76.

Accuracy. $--\mathrm{SE}_{7,2}=95$ percent, $\mathrm{SE}_{7,10}=95$ percent.

05391900 Noisy Creek near Rhinelander, Wis.

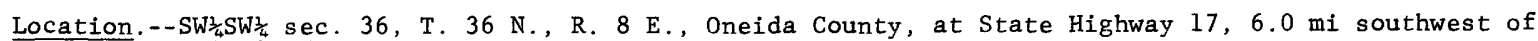
Rhinelander.

Drainage area. $--35.6 \mathrm{mi}^{2}$.

Tributary to. --Wisconsin River.

Type of site.--Low-flow partial-record station.

Minimum discharge measured. $--4.86 \mathrm{ft}^{3} / \mathrm{s}$, Aug. 11, 1970.

Low-flow frequency. $-Q_{7,2}=5.0 \mathrm{ft}^{3} / \mathrm{s}, Q_{7,10}=3.2 \mathrm{ft}^{3} / \mathrm{s}$.

Basis of estimate.--Graphical regression with Prairie River near Merrill using 12 discharge measurements made during the period 1968-79.

Accuracy. $--\mathrm{SE}_{7,2}=12$ percent, $\mathrm{SE}_{7,10}=17$ percent. 
05391950 Squaw Creek near Harrison, Wis.

Location. $-\mathrm{NW}^{\frac{1}{4}} \mathrm{SW} \frac{\mathrm{l}}{4} \mathrm{sec} .3, \mathrm{~T} .35 \mathrm{~N} .$, R. 8 E., Lincoln County, at County Trunk A, 5.0 mi northeast of Harrison.

Drainage area. $--3.23 \mathrm{mi}^{2}$. Tributary to.--Wisconsin River.

Type of site.--Miscellaneous site.

Discharge measurement.--Sept. $27,1979,1.30 \mathrm{ft}^{3} / \mathrm{s}$.

Low-flow frequency. $-Q_{7,2}=0.93 \mathrm{ft}^{3} / \mathrm{s}, Q_{7,10}=0.57 \mathrm{ft}^{3} / \mathrm{s}$.

Basis of estimate.--Used multiple-regression equations 3 and 5 .

Accuracy. $--\mathrm{SE}_{7,2}=36$ percent, $\mathrm{SE}_{7,10}=48$ percent.

05391958 Crescent Creek near Woodboro, Wis.

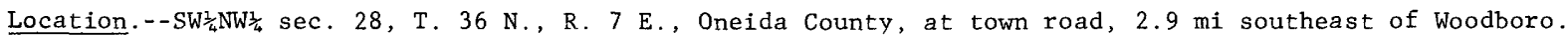

Drainage area. $-14.8 \mathrm{mi}^{2}$.

Tributary to. - Wiscons in River.

Type of site.--Miscellaneous site.

Discharge measurement.--Sept. 25, $1979,1.30 \mathrm{ft}^{3} / \mathrm{s}$.

Low-flow frequency. $-Q_{7,2}=1.6 \mathrm{ft}^{3} / \mathrm{s}, Q_{7,10}=0.84 \mathrm{ft}^{3} / \mathrm{s}$.

Basis of estimate.--Used multiple-regression equations 3 and 5 .

Accuracy. $--\mathrm{SE}_{7,2}=36$ percent, $\mathrm{SE}_{7,10}=48$ percent.

05392000 Wisconsin River at Whirlpool Rapids near Rhinelander, Wis.

Location. - - NW $\frac{1}{4} N_{1} \frac{1}{4}$ sec. 4, T. 35 N., R. 8 E., Lincoln County, at head of Whirlpool Rapids, 7.6 mi southwest of Rhinelander.

Drainage area. $--1,220 \mathrm{mi}^{2}$.

Tributary to.--Mississippi River

Type of site.--Gaging station.

Period of record.--0ct. 1905 to Sept. 1961.

Average discharge. --56 years, $1,108 \mathrm{ft}^{3} / \mathrm{s}$.

Extremes.--Maximum discharge, 5,590 ft³/s Sept. 9, 1941; minimum discharge, no flow Aug. 4, Sept. 15, 1907, June 21 , July 5,1908 .

Period Magnitude and frequency of annual low flow

of con- Discharge, in cubic feet per second, for

days indicated recurrence interval, in years

\begin{tabular}{rrrrrrr}
\hline & 2 & 5 & 10 & 20 & 50 & 100 \\
\hline 7 & 530 & 389 & 324 & 276 & 230 & 199 \\
30 & 570 & 424 & 358 & 308 & 260 & 227 \\
60 & 623 & 462 & 388 & 332 & 280 & 241 \\
90 & 674 & 506 & 432 & 377 & 330 & 289 \\
\hline
\end{tabular}

Duration table of daily flow

Discharge, in cubic feet per second, which was exceeded for indicated percent of time

\begin{tabular}{crrrrrr}
\hline $\begin{array}{c}\text { Percent } \\
\mathrm{ft}\end{array}$ & 2 & 5 & 10 & 20 & 30 & 40 \\
\hline $\begin{array}{c}\text { Percent } \\
\mathrm{ft}\end{array}$ & 2,850 & 2,300 & 1,820 & 1,410 & 1,200 & 1,060 \\
\hline $\begin{array}{c}\text { Percent } \\
\mathrm{ft}\end{array}$ & 940 & 80 & 70 & 80 & 90 & 95 \\
\hline
\end{tabular}

Accuracy. $--\mathrm{SE}_{7,2}=5$ percent, $\mathrm{SE}_{7,10}=8$ percent.

Remarks.--Flow is regulated by 15 reservoirs above station. Minimum flow of zero was caused by regulation. See Gebert and Holmstrom (1977) for additional analyses. 
Table 1.--Low-flow characteristics for sites in the upper Wisconsin River basin--Continued

05392020 Big Pine Creek near Harrison, Wis.

Location. - -SW $\frac{1}{4} \mathrm{SE}_{\frac{1}{4}} \mathrm{sec} .26$, T. $35 \mathrm{~N}$, R. 7 E., Lincoln County, at end of trail, 3.3 mi west of Harrison. Drainage area. $--29.4 \mathrm{mi}^{2}$. Tributary to. - -Visconsin River.

Type of site. --Miscellaneous site.

Discharge measurements.--Oct. 13, $1971,26.0 \mathrm{ft}^{3} / \mathrm{s} ;$ Sept. $27,1979,10.4 \mathrm{ft}^{3} / \mathrm{s}$.

Low-flow frequency. $-Q_{7,2}=8.4 \mathrm{ft}^{3} / \mathrm{s}, Q_{7,10}=5.9 \mathrm{ft}^{3} / \mathrm{s}$.

Basis of estimate.--Used multiple-regression equations 3 and 5.

Accuracy. $--\mathrm{SE}_{7,2}=36$ percent, $\mathrm{SE}_{7,10}=48$ percent.

05392031 Muskellunge Creek near Tomahawk, Wis.

Location. - -SW $\frac{1}{4} \mathrm{SW}_{\frac{1}{4}} \mathrm{sec} .23$, T. $35 \mathrm{~N} ., \mathrm{R} .6 \mathrm{E}$., Lincoln County, on town road, 2.0 mi northeast of Tomahawk. Drainage area. $--8.18 \mathrm{mi}^{2}$. Tributary to.--Wisconsin River.

Type of site.--Miscellaneous site.

Discharge measurement.--Sept. $24,1979,3.01 \mathrm{ft}^{3} / \mathrm{s}$.

Low-flow frequency. $-Q_{7,2}=2.4 \mathrm{ft}^{3} / \mathrm{s}, 0,7,10=1.5 \mathrm{ft}^{3} / \mathrm{s}$.

Basis of estimate.--Used multiple-regression equations 3 and 5 .

Accuracy. $--\mathrm{SE}_{7,2}=36$ percent, $\mathrm{SE}_{7,10}=48$ percent.

05392077 Tomahawk River tributary near Woodruff, Wis .

Location.-- $-\mathrm{NW} \frac{1}{4} \mathrm{NW} \frac{1}{4} \mathrm{sec} .8$, T. $39 \mathrm{~N} ., \mathrm{R} .7 \mathrm{E}$. , Oneida County, at culvert on County Trunk J, 2.4 mi east of
Woodruff. Drainage area. $--21.9 \mathrm{mi}^{2}$. Tributary to. - - Tomahawk River.

Type of site.--Miscellaneous site.

Discharge measurements.--July 14, 1975, $6.89 \mathrm{ft}^{3} / \mathrm{s} ;$ Aug. 1, 1975, $4.72 \mathrm{ft}{ }^{3} / \mathrm{s} ;$ Sept. 15, $1976,1.15 \mathrm{ft} / \mathrm{s}$. Low-flow frequency. $--_{7,2}=4.7 \mathrm{ft}^{3} / \mathrm{s}, 0,7,10=0.68 \mathrm{ft}^{3} / \mathrm{s}$.

Basis of estimate.--Graphical regression with Spirit River near Spirit Falls using 3 discharge measurements made during the period $1975-76$.

Accuracy. $-\mathrm{SE}_{7,10}=38$ percent (basin average).

05392102 Tomahawk River near Minocqua, Wis .

Location.-- $-\mathrm{NW}_{4} \mathrm{SE} \frac{1}{4} \mathrm{sec}, 9, \mathrm{~T} .39 \mathrm{~N}, \mathrm{R}, 6 \mathrm{~F}$. , Oneida County, at bridge on State Highway $70,1.8 \mathrm{mi}$ west of
Minocqua. Drainage area. $--73.0 \mathrm{mi}^{2}$. Tributary to. - -Wisconsin River.

Type of site.--Miscellaneous site.

Minimum discharge measured. $--5.37 \mathrm{ft}^{3} / \mathrm{s}$, Sept. 26, 1979.

Low-flow frequency. $-Q_{7,2}=12 \mathrm{ft}^{3} / \mathrm{s}, 0,7,10=6.5 \mathrm{ft}^{3} / \mathrm{s}$.

Basis of estimate. - Graphical regression with Spirit River at Spirit Falls using 11 discharge measurements made during the period 1971-79.

Accuracy. $--\mathrm{SE}_{7,2}=83$ percent, $\mathrm{SE}_{7,10}=83$ percent. 
Table 1.--Low-flow characteristics for sites in the upper Wisconsin River basin--Continued

05392150 Mishonagon Creek near Woodruff, Wis.

Location. - $-\mathrm{NE}_{\frac{1}{4}} \mathrm{NE}_{\frac{1}{4}} \mathrm{sec} .32$, T. $40 \mathrm{~N}$, R. 6 E., Vilas County, at State Highway $47,3.0$ mi northwest of Woodruff. Drainage area. $--17.6 \mathrm{mi}^{2}$. Tributary to. --Tomahawk River.

Type of site.--Low-flow partial-record station.

Minimum discharge measured.--13.0 $\mathrm{ft}^{3} / \mathrm{s}$, Sept. $26,1979$.

Low-flow frequency. $-Q_{7,2}=13 \mathrm{ft}^{3} / \mathrm{s}, Q_{7,10}=11 \mathrm{ft}^{3} / \mathrm{s}$.

Basis of estimate.--Graphic regression with Spirit River at Spirit Falls using 19 discharge measurements made during the period 1961-79.

Accuracy.--SE $7,2=10$ percent, $\mathrm{SE}_{7,10}=17$ percent.

05392160 Tomahawk River tributary near Minocqua, Wis.

Location.-- $\mathrm{NW}_{\frac{1}{4}} \mathrm{NE}_{\frac{1}{4}} \mathrm{sec} .12$, T. $39 \mathrm{~N}$, R. 5 E., Oneida County, at bridge on State Highway $70,4.7 \mathrm{mi}$ west of Minocqua.

Drainage area $--6.26 \mathrm{mi}^{2}$. Tributary to. --Tomahawk River.

Type of site.--Miscellaneous site.

Discharge measurements.--0ct. $12,1971,8.85 \mathrm{ft}^{3} / \mathrm{s}$; Sept. $26,1979,4.21 \mathrm{ft}^{3} / \mathrm{s}$.

Low-flow frequency. $-Q_{7,2}=3.6 \mathrm{ft}^{3} / \mathrm{s}, Q_{7,10}=2.6 \mathrm{ft}^{3} / \mathrm{s}$.

Basis of estimate.--Used multiple-regression equations 3 and 5 .

Accuracy. $--\mathrm{SE}_{7,2}=36$ percent, $\mathrm{SE}_{7,10}=48$ percent.

05392202 Squirrel River near Minocqua, Wis.

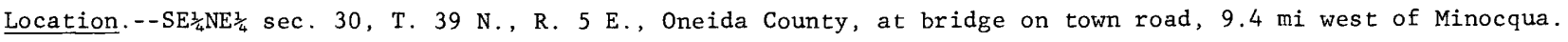
Drainage area. $--15.5 \mathrm{mi}^{2}$. Tributary to. --Tomahawk River.

Type of site.--Miscellaneous site.

Discharge measurements.--Oct. 12, $1971,46.9 \mathrm{ft}^{3} / \mathrm{s}$; Sept. 26, 1979, $16.2 \mathrm{ft}^{3} / \mathrm{s}$.

Low-flow frequency. $-Q_{7,2}=12 \mathrm{ft}^{3} / \mathrm{s}, Q_{7,10}=9.8 \mathrm{ft}^{3} / \mathrm{s}$.

Basis of estimate.--Used multiple-regression equations 3 and 5 .

Accuracy. $-\mathrm{SE}_{7,2}=36$ percent, $\mathrm{SE}_{7,10}=48$ percent.

05392220 Tomahawk River near Hazelhurst, Wis.

Location. - $-\mathrm{SE}_{\frac{1}{4}} \mathrm{NE}^{\frac{1}{4}} \mathrm{sec} .2$, T. $38 \mathrm{~N}$., R. 5 E., Oneida County, at bridge on Camp Nine Road, $4.5 \mathrm{mi}$ west of Drainage area. $--165 \mathrm{mi}^{2}$. Tributary to.--Wisconsin River.

Type of site.--Miscellaneous site.

Discharge measurements.--0ct. 13, 1971, $344 \mathrm{ft}^{3} / \mathrm{s} ;$ Sept. $26,1979,66.1 \mathrm{ft}^{3} / \mathrm{s}$. 
05392227 Threemile Creek near Hazelhurst, Wis.

Location. - $-\mathrm{NW} \frac{1}{4} \mathrm{NW}_{\frac{1}{4}} \mathrm{sec} .5$, T. 38 N., R. 6 E., Oneida County, on town road, 2.4 mi west of Hazelhurst.

Drainage area. $--4.97 \mathrm{mi}^{2}$.

Tributary to. --Kaubashine Creek.

Type of site.--Miscellaneous site.

Discharge measurement.--Sept. $26,1979,0.37 \mathrm{ft}^{3} / \mathrm{s}$.

Low-flow frequency. $-Q_{7,2}=0.60 \mathrm{ft}^{3} / \mathrm{s}, 0,7,10=0.29 \mathrm{ft}^{3} / \mathrm{s}$.

Basis of estimate. --Used multiple-regression equations 3 and 5 .

Accuracy.-- $\mathrm{SE}_{7,2}=36$ percent, $\mathrm{SE}_{7,10}=48$ percent.

05392233 Kaubashine Creek near Hazelhurst, Wis.

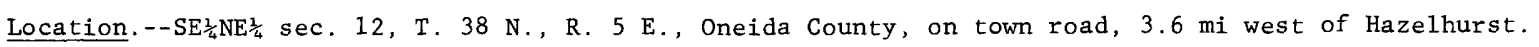

Drainage area. $--18.4 \mathrm{mi}^{2}$.

Tributary to. --Tomahawk River.

Type of site.--Miscellaneous site.

Discharge measurement.--Sept. $27,1979,10.3 \mathrm{ft}^{3} / \mathrm{s}$.

Low-flow frequency. $-Q_{7,2}=9.2 \mathrm{ft}^{3} / \mathrm{s}, 0,7,10=7.0 \mathrm{ft}^{3} / \mathrm{s}$.

Basis of estimate.--Used multiple-regression equations 3 and 5 .

Accuracy. $--\mathrm{SE}_{7,2}=36$ percent, $\mathrm{SE}_{7,10}=48$ percent.

05392240 Tomahawk River near Hazelhurst, Wis.

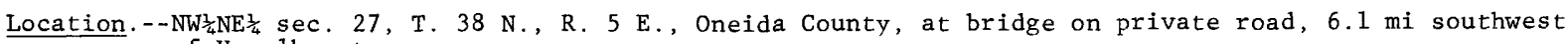
of Hazelhurst.

Drainage area. $--189 \mathrm{mi}^{2}$. Tributary to. --Wisconsin River.

Type of site. - -Miscellaneous site.

Discharge measurements.--Nov. 30, 1972, $272 \mathrm{ft}^{3} / \mathrm{s}$; Sept. $27,1979,73.3 \mathrm{ft} / \mathrm{s}$.

05392290 Willow River near Hazelhurst, Wis .

Location. $--\operatorname{SE}_{\frac{1}{4}} \mathrm{SE}_{\frac{1}{4}} \mathrm{sec} .19$, T. $38 \mathrm{~N} .$, R. 4 E., Oneida County, at town road, 14.9 mi west of Hazelhurst. Drainage area. $--9.92 \mathrm{mi}^{2}$. Tributary to.--Tomahawk River.

Type of site.--Low-flow partial-record station.

Minimum discharge measured. $--1.84 \mathrm{ft}^{3} / \mathrm{s}$, Aug. 26, 1970.

Low-flow frequency. $-Q_{7,2}=2.1 \mathrm{ft}^{3} / \mathrm{s}, Q_{7,10}=1.5 \mathrm{ft}^{3} / \mathrm{s}$.

Basis of estimate.--Graphical regression with Prairie River near Merrill using 10 discharge measurements made during the period 1969-79.

Accuracy.--SE $7,2=36$ percent, $\mathrm{SE}_{7,10}=55$ percent.

053922926 Thunder River near Tripoli, Wis .

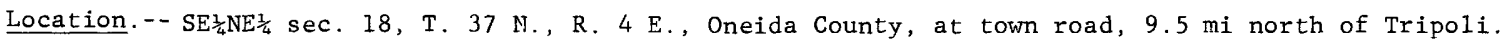

Drainage area. $--11.8 \mathrm{mi}^{2}$. Tributary to. - Willow River.

Type of site.--Miscellaneous site.

Discharge measurement.--Sept. $26,1979,1.34 \mathrm{ft}^{3} / \mathrm{s}$.

Low-flow frequency. $-Q_{7,2}=0.86 \mathrm{ft}^{3} / \mathrm{s}, Q_{7,10}=0.47 \mathrm{ft}^{3} / \mathrm{s}$.

Basis of estimate. - Used multiple-regression equations 3 and 5 .

Accuracy. $-\mathrm{SE}_{7,2}=36$ percent, $\mathrm{SE}_{7,10}=48$ percent. 
Table 1.--Low-flow characteristics for sites in the upper Wisconsin River basin--Continued

05392295 Willow River near Tripoli, Wis.

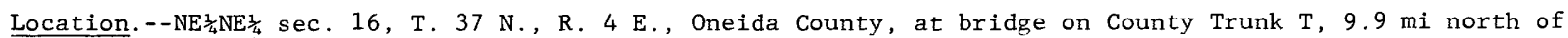
Tripoli.

Drainage area. $--61.0 \mathrm{mi}^{2}$. Tributary to.--Tomahawk River.

Type of site.--Miscellaneous site.

Discharge measurements.--Oct. 12, 1971, $127 \mathrm{ft}^{3} / \mathrm{s}$; Nov. $30,1972,57.6 \mathrm{ft}^{3} / \mathrm{s}$.

05392298 Swampsauger Creek near Hazelhurst, Wis.

Location. $--\mathrm{SE}_{\frac{1}{4}} \mathrm{SW}_{\frac{1}{4}} \mathrm{sec} .36$, T. 38 N., R. 4 E., Oneida County, at bridge on town road, 11.3 mi southwest of Hazelhurst.

Drainage area.--15.8 $\mathrm{mi}^{2}$. Tributary to.--Willow River.

Type of site.--Miscellaneous site.

Discharge measurements.--Oct. 12, $1971,29.0 \mathrm{ft}^{3} / \mathrm{s}$; Sept. $26,1979,2.98 \mathrm{ft}^{3} / \mathrm{s}$.

Low-flow frequency. $-Q_{7,2}=3.5 \mathrm{ft}^{3} / \mathrm{s}, Q_{7,10}=2.2 \mathrm{ft}^{3} / \mathrm{s}$.

Basis of estimate.--Used multiple-regression equations 3 and 5 .

Accuracy. $--\mathrm{SE}_{7,2}=36$ percent, $\mathrm{SE}_{7,10}=48$ percent.

05392300 Willow Reservoir near Hazelhurst, Wis .

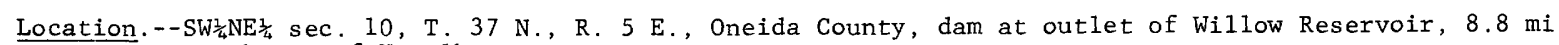
southwest of Hazelhurst.

Drainage area. $--310 \mathrm{mi}^{2}$.

Tributary to. --Wisconsin River.

Type of site.-- Miscellaneous site.

Discharge measurement.--Dec. 1, 1972, $730 \mathrm{ft}^{3} / \mathrm{s}$.

05392305 Bear Creek near Goodnow, Wis .

Location.--SW $\frac{1}{4} \mathrm{NW}_{\frac{1}{4}} \mathrm{sec} .13$, T. 37 N., R. 5 E., Oneida County, at bridge on County Trunk Y, $6.8 \mathrm{mi}$ west of Goodnow.

Drainage area. $--6.20 \mathrm{mi}^{2}$.

Tributary to. --Tomahawk River.

Type of site.--Miscellaneous site.

Discharge measurements.--0ct. 13, 1971, $12.2 \mathrm{ft}^{3} / \mathrm{s} ;$ Sept. $25,1979,3.64 \mathrm{ft}^{3} / \mathrm{s}$.

Low-flow frequency. $-Q_{7,2}=2.7 \mathrm{ft}^{3} / \mathrm{s}, Q_{7,10}=1.8 \mathrm{ft}^{3} / \mathrm{s}$.

Basis of estimate.--Used multiple-regression equations 3 and 5 .

Accuracy.-- $\mathrm{SE}_{7,2}=36$ percent, $\mathrm{SE}_{7,10}=48$ percent.

05392320 Rocky Run Creek near Goodnow, Wis .

Location. $--\mathrm{SE}_{\frac{1}{4}} \mathrm{SE}_{\frac{1}{4}} \mathrm{sec} .17$, T. 37 N., R. 6 E., Oneida County, at town road, 4.3 mi west of Goodnow.

Drainage area.--23.2 $\mathrm{mi}^{2}$. Tributary to.--Tomahawk River.

Type of site.--Low-flow partial-record station.

Minimum discharge measured. $--11.5 \mathrm{ft}^{3} / \mathrm{s}$, Sept. 16, 1976.

Low-flow frequency. $--Q_{7,2}=15 \mathrm{ft}^{3} / \mathrm{s}, Q_{7,10}=12 \mathrm{ft}^{3} / \mathrm{s}$.

Basis of estimate.--Graphical regression with Prairie River near Merrill using 13 discharge measurements made during the period 1969-79.

Accuracy. $--\mathrm{SE}_{7,2}=16$ percent, $\mathrm{SE}_{7,10}=22$ percent. 
05392350 Bearskin Creek near Harshaw, Wis.

Location.--SE $\frac{1}{4} \mathrm{SW}_{\frac{1}{4}} \mathrm{sec} .36$, T. 37 N., R. 6 E., Oneida County, at County Trunk K, 2.1 mi southwest of Harshaw. Drainage area. $--31.1 \mathrm{mi}^{2}$. Tributary to. - - Tomahawk River.

Type of site.--Low-flow partial-record station.

Minimum discharge measured. $--19.7 \mathrm{ft}^{3} / \mathrm{s}$, Aug. 4, 1964 .

Low-flow frequency. $-Q_{7,2}=23 \mathrm{ft}^{3} / \mathrm{s}, Q_{7,10}=19 \mathrm{ft}^{3} / \mathrm{s}$.

Basis of estimate.--Graphical regression with Spirit River near Spirit Falls using 34 discharge measurements made during the period 1962-79.

Accuracy. $--\mathrm{SE}_{7,2}=6$ percent, $\mathrm{SE}_{7,10}=9$ percent.

05392378 Swamp Creek near Bradley, Wis .

Location. - $-\mathrm{NE} \frac{1}{4} \mathrm{SW} \frac{1}{4} \mathrm{sec} .9$, T. $36 \mathrm{~N} .$, R. 6 E., Oneida County, on town road, 5.8 mi north of Bradley.

Drainage area. $--11.7 \mathrm{mi}^{2}$.

Tributary to. --Tomahawk River.

Type of site.--Miscellaneous site.

Discharge measurement.--Sept. 25, 1979, $4.80 \mathrm{ft}^{3} / \mathrm{s}$.

Low-flow frequency. $-Q_{7,2}=4.5 \mathrm{ft}^{3} / \mathrm{s}, Q_{7,10}=3.1 \mathrm{ft}^{3} / \mathrm{s}$.

Basis of estimate.--Used multiple-regression equations 3 and 5 .

Accuracy. $--\mathrm{SE}_{7,2}=36$ percent, $\mathrm{SE}_{7,10}=48$ percent.

05392400 Tomahawk River near Bradley, Wis.

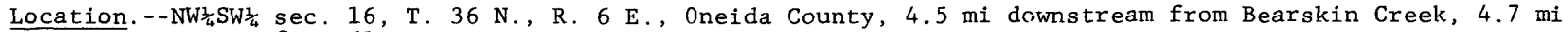
north of Bradley.

Drainage area. $--422 \mathrm{mi}^{2}$.

Tributary to. --Wisconsin River.

Type of site.--Gaging station.

Period of record.--September 1914 to September 1927, partial records available for 1929 water year.

Average discharge. --14 years, $435 \mathrm{ft}^{3} / \mathrm{s}$.

Extremes.--Maximum discharge, 2, $200 \mathrm{ft}^{3} / \mathrm{s} \mathrm{Apr.} \mathrm{24,} \mathrm{1916;} \mathrm{minjmum} \mathrm{discharge,} 120 \mathrm{ft}^{3} / \mathrm{s}$ May 23-29, 1927.

\begin{tabular}{lrrrr}
\hline $\begin{array}{l}\text { Period } \\
\text { of con- } \\
\text { secutive } \\
\text { days }\end{array}$ & $\begin{array}{l}\text { Magnitude and frequency of annual low flow } \\
\text { Discharge, in cubic feet per second, for } \\
\text { indicated recurrence interva1, in years } \\
\text { ind }\end{array}$ \\
\hline & 2 & 5 & 10 & 20 \\
7 & 206 & 169 & 152 & 139 \\
14 & 226 & 189 & 172 & 159 \\
30 & 241 & 201 & 184 & 170 \\
60 & 266 & 222 & 201 & 185 \\
90 & 284 & 236 & 214 & 197 \\
\hline
\end{tabular}

\begin{tabular}{|c|c|c|c|c|c|c|c|}
\hline $\begin{array}{l}\text { Discharg } \\
\text { was exce }\end{array}$ & $\begin{array}{l}\text { dration } \\
\text { eded } \mathrm{fc}\end{array}$ & $\begin{array}{l}\text { tabl } \\
\text { abic } \\
\text { c inc }\end{array}$ & $\begin{array}{l}\text { of } \\
\text { ieet } \\
\text { cate }\end{array}$ & $\begin{array}{l}\text { daily } \\
\text { per s } \\
\text { d per }\end{array}$ & $\begin{array}{l}\text { flow } \\
\text { econd } \\
\text { eent }\end{array}$ & wh $t$ & \\
\hline Percent & 2 & 5 & 10 & 20 & 30 & 40 & 50 \\
\hline $\mathrm{ft}^{3} / \mathrm{s}$ & 1,190 & 860 & 710 & 560 & 460 & 400 & 350 \\
\hline Percent & 60 & 70 & 80 & 90 & 95 & 98 & 99.9 \\
\hline$f t^{3} / s$ & 320 & 290 & 270 & 240 & 215 & 180 & 140 \\
\hline
\end{tabular}

Accuracy. $--\mathrm{SE}_{7,2}=6$ percent, $\mathrm{SE}_{7,10}=9$ percent

Remarks.--Flow regulated by two reservoirs before 1927 and three since May 1927. 
Table 1.--Low-flow characteristics for sites in the upper Wisconsin River basin--Continued

05392405 Rice Creek near Harshaw, Wis.

Location. $--\mathrm{NW}_{\frac{1}{4}} \mathrm{NW}^{\frac{1}{4}} \mathrm{sec} .3$, T. $36 \mathrm{~N}$., R. 7 E., Oneida County, at bridge on County Trunk K, 2.8 mi southeast of Harshaw.

Drainage area.--18.1 $\mathrm{mi}^{2}$. Tributary to.--Tomahawk River.

Type of site.--Miscellaneous site.

Discharge measurements.--0ct. $14,1971,15.7 \mathrm{ft} / \mathrm{s} ;$ Sept. $25,1979,8.86 \mathrm{ft}^{3} / \mathrm{s}$.

Low-flow frequency. $-Q_{7,2}=6.7 \mathrm{ft}^{3} / \mathrm{s}, Q_{7,10}=4.7 \mathrm{ft}^{3} / \mathrm{s}$.

Basis of estimate.--Used multiple-regression equations 3 and 5 .

Accuracy.-- $-\mathrm{SE}_{7,2}=36$ percent, $\mathrm{SE}_{7,10}=48$ percent.

05392407 Trout Creek near Woodboro, Wis .

Location. - $-\mathrm{NE}_{\frac{1}{4}} \mathrm{SW}_{\frac{1}{4}} \mathrm{sec} .15, \mathrm{~T} .36 \mathrm{~N}, \mathrm{R} .7 \mathrm{E}$, Oneida County, on town road, $2.4 \mathrm{mi}$ west of Woodboro.

Drainage area. $--2.22 \mathrm{mi}^{2}$. Tributary to.--Little Rice Creek.

Type of site.--Miscellaneous site.

Discharge measurement.--Sept. $24,1979,5.51 \mathrm{ft}^{3} / \mathrm{s}$.

Low-flow frequency. $-Q_{7,2}=2.7 \mathrm{ft}^{3} / \mathrm{s}, Q_{7,10}=2.1 \mathrm{ft}^{3} / \mathrm{s}$.

Basis of estimate.--Used multiple-regression equations 3 and 5 .

Accuracy. $--\mathrm{SE}_{7,2}=36$ percent, $\mathrm{SE}_{7,10}=48$ percent.

05392410 Little Rice Creek near Heafford Junction, Wis.

Location. - $-\mathrm{NW}_{\frac{1}{4}} \mathrm{NW} \frac{1}{4} \mathrm{sec} .31, \mathrm{~T} .36 \mathrm{~N} ., \mathrm{R} .7 \mathrm{E}$, Oneida County, at bridge on County Trunk $\mathrm{N}, 2.4 \mathrm{mi}$ northeast of Heafford Junction.

Drainage area. $--36.9 \mathrm{mi}^{2}$. Tributary to.--Tomahawk River.

Type of site.--Miscellaneous site.

Discharge measurements.--Oct. $14,1971,37.8 \mathrm{ft}^{3} / \mathrm{s} ;$ Sept. $24,1979,24.6 \mathrm{ft}^{3} / \mathrm{s}$.

Low-flow frequency. $-Q_{7,2}=16 \mathrm{ft}^{3} / \mathrm{s}, Q_{7,10}=12 \mathrm{ft}^{3} / \mathrm{s}$.

Basis of estimate.--Used multiple-regression equations 3 and 5 .

Accuracy.-- $\mathrm{SE}_{7,2}=36$ percent, $\mathrm{SE}_{7,10}=48$ percent.

05392450 Little Rice River near Bradley, Wis.

Location.--SW $\frac{1}{4} \mathrm{NE}_{\frac{1}{4}} \mathrm{sec} .23$, T. 36 N., R. 5 E., Oneida County, at Kelly firelane, 5.4 mi northwest of Bradley. Drainage area. $--21.4 \mathrm{mi}^{2}$. Tributary to. - Tomahawk River.

Type of site.--Low-flow partial-record station.

Minimum discharge measured. $--0.17 \mathrm{ft}^{3} / \mathrm{s}$, Sept. 16, 1976.

Low-flow frequency. $-Q_{7,2}=0.88 \mathrm{ft}^{3} / \mathrm{s}, Q_{7,10}=0.32 \mathrm{ft}^{3} / \mathrm{s}$.

Basis of estimate.--Graphical regression with Prairie River near Merrill using 14 discharge measurements made during the period 1968-79.

Accuracy.--SE $7,2=56$ percent, $\mathrm{SE}_{7,10}=78$ percent. 
Table 1.--Low-flow characteristics for sites in the upper Wisconsin River basin--Continued

05392460 Brown Creek near McCord, Wis.

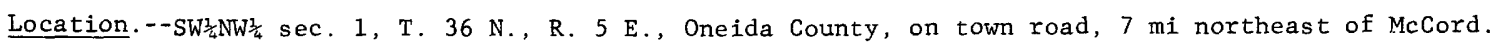

Drainage area. $--7.49 \mathrm{mi}^{2}$.

Tributary to. --Little Rice River.

Type of site.--Miscellaneous site.

Discharge measurement.--Sept. 25, 1979, $0.67 \mathrm{ft}^{3} / \mathrm{s}$.

Low-flow frequency. $-Q_{7,2}=0.99 \mathrm{ft}^{3} / \mathrm{s}, Q_{7,10}=0.51 \mathrm{ft}^{3} / \mathrm{s}$.

Basis of estimate.--Used multiple-regression equations 3 and 5 .

Accuracy.--SE $7,2=36$ percent, $\mathrm{SE}_{7,10}=48$ percent.

05393000 Tomahawk River at Bradley, Wis.

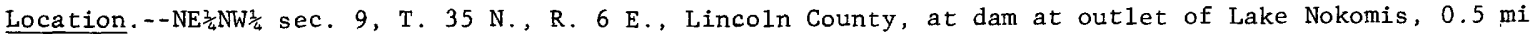
east of Bradley.

Drainage area. $--544 \mathrm{mi}^{2}$.

Tributary to.--Wisconsin River.

Type of site.--Gaging station.

Period of record.--January 1930 to September 1973.

Average discharge. -43 years, $542 \mathrm{ft}^{3} / \mathrm{s}$.

Extremes.--Maximum discharge, $2,690 \mathrm{ft} \frac{3}{\mathrm{~s}}$ Oct. 2, 1959; minimum discharge, no flow at times in 1931, 1932, 1934,1940 , and 1957 .

Period Magnitude and frequency of annual low flow

of con- Discharge, in cubic feet per second, for secutive indicated recurrence interval, in years days

\begin{tabular}{rrrrrrr}
\hline & 2 & 5 & 10 & 20 & 50 & 100 \\
\cline { 2 - 7 } 7 & 58 & 27 & 18 & 13 & 8.8 & 6.8 \\
14 & 72 & 32 & 21 & 15 & 10 & 7.7 \\
30 & 111 & 50 & 32 & 22 & 14 & 9.8 \\
60 & 224 & 134 & 101 & 79 & 60 & 49 \\
90 & 313 & 221 & 185 & 161 & 137 & 124 \\
\hline
\end{tabular}

Accuracy. $-\mathrm{SE}_{7,2}=14$ percent, $\mathrm{SE}_{7,10}=21$ percent. Remarks.--Flow regulated by four reservoirs.
Duration table of daily flow

\begin{tabular}{|c|c|c|c|c|c|c|c|}
\hline \multicolumn{8}{|c|}{$\begin{array}{l}\text { Discharge, in cubic feet per second, which } \\
\text { was exceeded for indicated percent of time }\end{array}$} \\
\hline \multirow{2}{*}{$\begin{array}{l}\text { Percent } \\
\mathrm{ft} \mathrm{t}^{3} / \mathrm{s}\end{array}$} & 2 & 5 & 10 & 20 & 30 & 40 & 50 \\
\hline & 1,240 & 1,020 & 920 & 780 & 680 & 600 & 530 \\
\hline \multirow{2}{*}{$\begin{array}{l}\text { Percent } \\
\mathrm{ft} \mathrm{t}^{3} / \mathrm{s}\end{array}$} & 60 & 70 & 80 & 90 & 95 & 98 & 99.9 \\
\hline & 450 & 370 & 270 & 150 & 75 & 27 & 0 \\
\hline
\end{tabular}

05393160 Somo Creek at Clifford, Wis.

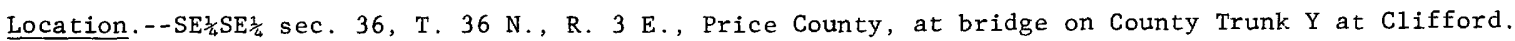

Drainage area. $--18.8 \mathrm{mi}^{2}$. Tributary to.--Wisconsin River.

Type of site.--Misce1laneous site.

Discharge measurements.--0ct. $12,1971,10.9 \mathrm{ft}^{3} / \mathrm{s} ; \operatorname{Sept} .24,1979,0.53 \mathrm{ft}^{3} / \mathrm{s}$.

Low-flow frequency. $-Q_{7,2}=0.46 \mathrm{ft}^{3} / \mathrm{s}, Q_{7,10}=0.20 \mathrm{ft}^{3} / \mathrm{s}$.

Basis of estimate.--Used multiple-regression equations 3 and 5 .

Accuracy. $-\mathrm{SE}_{7,2}=36$ percent, $\mathrm{SE}_{7,10}=48$ percent. 


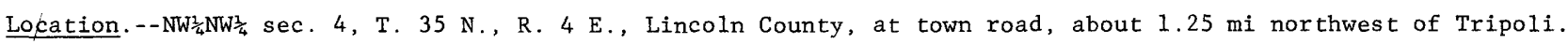
Drainage area. $-11.3 \mathrm{mi}^{2}$. Tributary to.--Somo Creek.

Type of site.--Miscellaneous site.

Discharge measurement.--Sept. $24,1979,0.69 \mathrm{ft}^{3} / \mathrm{s}$.

Low-flow frequency. $-Q_{7,2}=0.52 \mathrm{ft}^{3} / \mathrm{s}, Q_{7,10}=0.25 \mathrm{ft}^{3} / \mathrm{s}$.

Basis of estimate.--Used multiple-regression equations 3 and 5 .

Accuracy. $--\mathrm{SE}_{7,2}=36$ percent, $\mathrm{SE}_{7,10}=48$ percent.

\section{Somo River near Tripoli, Wis.}

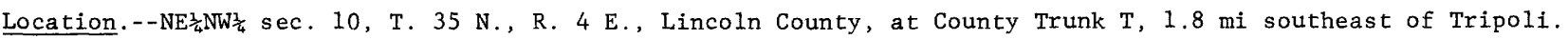
Drainage area. $--43.5 \mathrm{mi}^{2}$. Tributary to.--Wisconsin River.

Type of site.--Low-flow partia1-record station.

Minimum discharge measured. $-0.83 \mathrm{ft}^{3} / \mathrm{s}$, Sept. 15, 1976.

Low-flow frequency. $-Q_{7,2}=2.1 \mathrm{ft}^{3} / \mathrm{s}, Q_{7,10}=1.1 \mathrm{ft}^{3} / \mathrm{s}$.

Basis of estimate.--Graphical regression with Spirit River at Spirit Falls using 14 discharge measurements made during the period 1967-79.

Accuracy. $--\mathrm{SE}_{7,2}=21$ percent, $\mathrm{SE}_{7,10}=32$ percent.

05393350 Little Somo River near Tripoli, Wis .

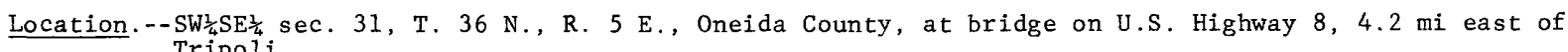
Drainage area. $--17.3 \mathrm{mi}^{2}$. Tributary to - - Somo River.

Type of site.--Miscellaneous site.

Discharge measurement.--0ct. $14,1971,17.3 \mathrm{ft}^{3} / \mathrm{s}$.

05393360 Johnson Creek near Tomahawk, Wis.

Location.-- $-\mathrm{SW}_{\frac{1}{4}} \mathrm{SE} \frac{1}{4} \mathrm{sec} .9$, T. 35 N., R. 5 E., Lincoln County, on County Trunk CC, about 7 mi northwest of Tomahawk.

Drainage area. $--6.41 \mathrm{mi}^{2}$. Tributary to - - Little Somo River.

Type of site.--Miscellaneous site.

Discharge measurement.--Sept. $24,1979,0.26 \mathrm{ft}^{3} / \mathrm{s}$.

Low-flow frequency. $-Q_{7,2}=0.46 \mathrm{ft}^{3} / \mathrm{s}, Q_{7,10}=0.20 \mathrm{ft}^{3} / \mathrm{s}$.

Basis of estimate.--Used multiple-regression equations 3 and 5 .

Accuracy. $--\mathrm{SE}_{7,2}=36$ percent, $\mathrm{SE}_{7,10}=48$ percent.

05393380 Hay Creek near Tomahawk, Wis.

Location.-- $\mathrm{SE}_{\frac{1}{4}} \mathrm{SE}_{\frac{1}{4}} \mathrm{sec}$. 14, T. 35 N., R. 5 E., Lincoln County, on County Trunk CC, about 4 mi northwest of Tomahawk.

Drainage area.--3.99 $\mathrm{mi}^{2} \quad$ Tributary to.--Little Somo River.

Type of site.--Miscellaneous site.

Discharge measurement.--Sept. $24,1979,0.06 \mathrm{ft}^{3} / \mathrm{s}$.

Low-flow frequency. $-Q_{7,2}=0.12 \mathrm{ft}^{3} / \mathrm{s}, Q_{7,10}=0.04 \mathrm{ft}^{3} / \mathrm{s}$.

Basis of estimate.--Used multiple-regression equations 3 and 5 .

Accuracy.--SE $7,2=36$ percent, $\mathrm{SE}_{7,10}=48$ percent. 
Table 1.--Low-flow characteristics for sites in the upper Wisconsin River basin--Continued

05393402 South Fork Spirit River near Spirit, Wis.

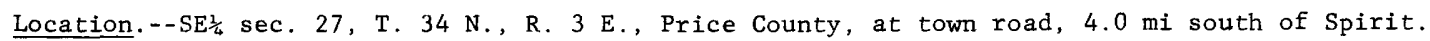

Drainage area. $--22.0 \mathrm{mi}^{2}$.

Tributary to. --Wisconsin River.

Type of site.--Miscellaneous site.

Discharge measurement. --Sept. $24,1979,2.95 \mathrm{ft}^{3} / \mathrm{s}$.

Low-flow frequency. $-Q_{7,2}=2.0 \mathrm{ft}^{3} / \mathrm{s}, 0_{7,10}=1.2 \mathrm{ft} / \mathrm{s}$.

Basis of estimate.--Used multiple-regression equations 3 and 5 .

Accuracy. $--\mathrm{SE}_{7,2}=36$ percent, $\mathrm{SE}_{7,10}=48$ percent.

05393440 North Fork Spirit River near Spirit, Wis.

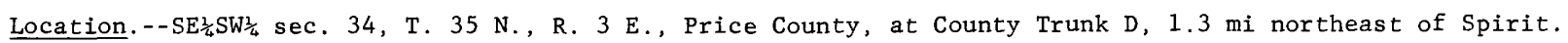
Drainage area. $--10.5 \mathrm{mi}^{2}$. Tributary to.--Spirit River.

Type of site.--Miscellaneous site.

Discharge measurement. --Sept. $24,1979,0.52 \mathrm{ft}^{3} / \mathrm{s}$.

Low-flow frequency. $-Q_{7,2}=0.47 \mathrm{ft}^{3} / \mathrm{s}, Q_{7,10}=0.22 \mathrm{ft}^{3} / \mathrm{s}$.

Basis of estimate.--Used multiple-regression equations 3 and 5 .

Accuracy. $--\mathrm{SE}_{7,2}=36$ percent, $\mathrm{SE}_{7,10}=48$ percent.

05393450 Knox Creek near Spirit, Wis.

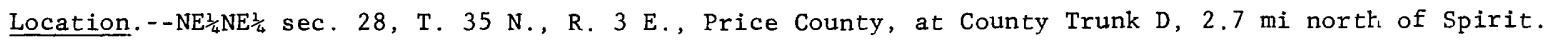

Drainage area. $--7.07 \mathrm{mi}^{2}$. Tributary to.--North Fork Spirit River.

Type of site.--Miscellaneous site.

Discharge measurement.--Sept. $24,1979,0.18 \mathrm{ft}^{3} / \mathrm{s}$.

Low-flow frequency. - $-Q_{7,2}=0.17 \mathrm{ft}^{3} / \mathrm{s}, Q_{7,10}=0.07 \mathrm{ft}^{3} / \mathrm{s}$.

Basis of estimate.--Used multiple-regression equations 3 and 5 .

Accuracy. $-\mathrm{SE}_{7,2}=36$ percent, $\mathrm{SE}_{7,10}=48$ percent.

05393460 North Fork Spirit River near Spirit, Wis.

Location. $--\mathrm{SW}_{\frac{1}{4}} \mathrm{SW}_{\frac{1}{4}} \mathrm{sec} .6, \mathrm{~T} .34 \mathrm{~N}$, , R. 4 E., Lincoln County, at bridge on State Highway $86,2.6 \mathrm{mi}$ east of Spirit.

Drainage area. $--22.8 \mathrm{mi}^{2}$. Tributary to -- Spirit River.

Type of site.--Miscellaneous site.

Discharge measurements. --0ct. 12, 1971, $9.10 \mathrm{ft}^{3} / \mathrm{s}$; Sept. $24,1979,0.88 \mathrm{ft}^{3} / \mathrm{s}$.

Low-flow frequency. $-Q_{7,2}=0.79 \mathrm{ft}^{3} / \mathrm{s}, Q_{7,10}=0.37 \mathrm{ft}^{3} / \mathrm{s}$.

Basis of estimate.--Used multiple-regression equations 3 and 5 .

Accuracy. $--\mathrm{SE}_{7,2}=36$ percent, $\mathrm{SE}_{7,10}=48$ percent. 
05393480 Ritchie Creek near Spirit, Wis.

Location.--SE $\frac{1}{4} S E \frac{1}{4}$ sec. 6 , T. 34 N., R. 4 E., Lincoln County, at bridge on State Highway 86 , 3.5 mi east of
Spirit. Drainage area. $--7.15 \mathrm{mi}^{2}$. Tributary to.--North Fork Spirit River.

Type of site.--Miscellaneous site.

Discharge measurements.--Oct. $12,1971,0.86 \mathrm{ft}^{3} / \mathrm{s} ;$ Sept. $24,1979,0.55 \mathrm{ft}^{3} / \mathrm{s}$.

Low-flow frequency. $-Q_{7,2}=0.37 \mathrm{ft}^{3} / \mathrm{s}, Q_{7,10}=0.18 \mathrm{ft}^{3} / \mathrm{s}$.

Basis of estimate.--Used multiple-regression equations 3 and 5 .

Accuracy. $--\mathrm{SE}_{7,2}=36$ percent, $\mathrm{SE}_{7,10}=48$ percent.

\section{Spirit River at Spirit Falls, Wis.}

Location.--SW $\frac{1}{4} \mathrm{NW} \frac{1}{4}$ sec. $10, \mathrm{~T} .34 \mathrm{~N} ., \mathrm{R} .4 \mathrm{E}$, Lincoln County, near center of span on downstream side of bridge, $0.2 \mathrm{mi}$ south of town of Spirit Falls, 0.6 mi upstream from Squaw Creek, 2.0 mi downstream from Ritchie Creek.

Drainage area. $--81.6 \mathrm{mi}^{2}$.

Tributary to.--Wisconsin River.

Type of site.--Gaging station.

Period of record.--April 1942 to September 1977.

Average discharge. --35 years, $83.3 \mathrm{ft}^{3} / \mathrm{s}$.

Extremes.--Maximum discharge, 4,180 $\mathrm{ft}^{3} / \mathrm{s}$ Sept. 18, 1942; minimum discharge, $1.0 \mathrm{ft} / \mathrm{s}$ Aug. 11,1964 .

\begin{tabular}{|c|c|c|c|c|c|c|}
\hline \multirow[t]{2}{*}{$\begin{array}{l}\text { Period } \\
\text { of con- } \\
\text { secutive } \\
\text { days }\end{array}$} & \multicolumn{6}{|c|}{$\begin{array}{l}\text { Magnitude and frequency of annual low flow } \\
\text { Discharge, in cubic feet per second, for } \\
\text { indicated recurrence interval, in years }\end{array}$} \\
\hline & 2 & 5 & 10 & 20 & 50 & 100 \\
\hline $\begin{array}{r}7 \\
14 \\
30 \\
60 \\
90\end{array}$ & $\begin{array}{r}5.1 \\
5.6 \\
7.3 \\
9.8 \\
12\end{array}$ & $\begin{array}{l}3.3 \\
3.6 \\
4.6 \\
6.2 \\
7.7\end{array}$ & $\begin{array}{l}2.5 \\
2.8 \\
3.6 \\
4.9 \\
6.2\end{array}$ & $\begin{array}{l}2.0 \\
2.3 \\
2.9 \\
4.1 \\
5.1\end{array}$ & $\begin{array}{l}1.5 \\
1.8 \\
2.2 \\
3.3 \\
4.2\end{array}$ & $\begin{array}{l}1.2 \\
1.6 \\
1.9 \\
2.9 \\
3.7\end{array}$ \\
\hline
\end{tabular}

Duration table of daily flow

Discharge, in cubic feet per second, which was exceeded for indicated percent of time

\begin{tabular}{rrrrrrrr}
\hline $\begin{array}{c}\text { Percent } \\
\mathrm{ft} t^{3} / \mathrm{s}\end{array}$ & 2 & 5 & 10 & 20 & 30 & 40 & 50 \\
\hline Percent & 60 & 70 & 80 & 90 & 95 & 98 & 99.9 \\
$\mathrm{ft} t^{3} / \mathrm{s}$ & 18 & 14 & 10 & 6.9 & 5.2 & 3.6 & 1.6 \\
\hline
\end{tabular}

Accuracy. $--\mathrm{SE}_{7,2}=9$ percent, $\mathrm{SE}_{7,10}=15$ percent.

05393520 Squaw Creek near Spirit, Wis.

Location.--SE $\frac{1}{4} S W \frac{3}{4}$ sec. 3, T. 34 N., R. 4 E., Lincoln County, at bridge on State Highway 86 , 5.7 mi east of Spirit.

Drainage area. $--19.7 \mathrm{mi}^{2}$.

Tributary to.--Spirit River.

Type of site.--Miscellaneous site.

Discharge measurements.--June $29,1971,2.06 \mathrm{ft}^{3} / \mathrm{s} ;$ Oct. 12, 1971, 6.6 ft $\mathrm{f}^{3} / \mathrm{s} ; \mathrm{Sept} .24,1979,1.35 \mathrm{ft} / \mathrm{s}$.

Low-flow frequency. $-\mathrm{Q}_{7,2}=0.90 \mathrm{ft}^{3} / \mathrm{s}, \mathrm{Q}_{7,10}=0.45 \mathrm{ft}^{3} / \mathrm{s}$.

Basis of estimate.--Graphical regression with Spirit River near Spirit Falls using 3 discharge measurements.

Accuracy. $--\mathrm{SE}_{7,2}=28$ percent, $\mathrm{SE} 7,10=38$ percent (basin average). 
Table 1.--Low-flow characteristics for sites in the upper Wisconsin River basin--Continued

05393560 Armstrong Creek near Tomahawk, Wis .

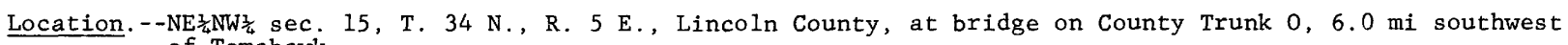
of Tomahawk.

Drainage area. $--13.0 \mathrm{mi}^{2}$. Tributary to.--Soirit River.

Type of site.--Miscellaneous site.

Discharge measurements.--June 29, 1971, $1.70 \mathrm{ft}^{3} / \mathrm{s} ; 0 \mathrm{ct} .12,1971,3.45 \mathrm{ft} / \mathrm{s} ;$ Sept. $24,1979,0.36 \mathrm{ft} / \mathrm{s}$. Low-flow frequency. $-Q_{7,2}=0.29 \mathrm{ft}^{3} / \mathrm{s}, Q_{7,10}=0.10 \mathrm{ft}^{3} / \mathrm{s}$.

Basis of estimate.--Graphical regression with Spirit River near Spirit Falls using 3 discharge measurements. Accuracy. $-\mathrm{SE}_{7,2}=28$ percent, $\mathrm{SE}_{7,10}=38$ percent (basin average).

05393572 Coffee Creek near Tomahawk, Wis.

Location. - $-\mathrm{SE}_{\frac{1}{4}} \mathrm{SW} \frac{1}{4} \mathrm{sec} .13$, T. $34 \mathrm{~N}$, R. $5 \mathrm{E}$. , Lincoln County, $5.4 \mathrm{mi}$ southwest of Tomahawk.

Drainage area. $--4.68 \mathrm{mi}^{2}$.

Tributary to.--Spirit River.

Type of site.--Miscellaneous site.

Discharge measurement.--Sept. $24,1979,0.12 \mathrm{ft}^{3} / \mathrm{s}$.

Low-flow frequency. $-Q_{7,2}=0.24 \mathrm{ft}^{3} / \mathrm{s}, Q_{7,10}=0.10 \mathrm{ft}^{3} / \mathrm{s}$.

Basis of estimate.--Used multiple-regression equations 3 and 5.

Accuracy. $-\mathrm{SE}_{7,2}=36$ percent, $\mathrm{SE}_{7,10}=48$ percent.

05393600 Spirit River Flowage near Tomahawk, Wis.

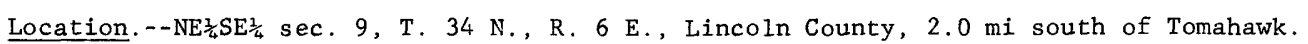

Drainage area. $--158 \mathrm{mi}^{2}$. Tributary to. --Wisconsin River.

Type of site.--Gaging station.

Discharge measurement.--Jan. 15, 1976, $114 \mathrm{ft}^{3} / \mathrm{s}$.

05393620 Skanawan Creek near Tomahawk, Wis.

Location. - -SW $\frac{1}{4} S W \frac{1}{4} \mathrm{sec} .13, \mathrm{~T} .34 \mathrm{~N}$, R. 6 E., Lincoln County, at bridge on State Highway $107,3.5 \mathrm{mi}$ southeast of Tomahawk.

Drainage area. $--6.69 \mathrm{mi}^{2}$. Tributary to.--Wisconsin River.

Type of site.--Miscellaneous site.

Discharge measurement.--Sept. $24,1979,5.52 \mathrm{ft}^{3} / \mathrm{s}$.

Low-flow frequency. $-Q_{7,2}=4.1 \mathrm{ft}^{3} / \mathrm{s}, Q_{7,10}=3.0 \mathrm{ft}^{3} / \mathrm{s}$.

Basis of estimate.--Used multiple-regression equations 3 and 5 .

Accuracy. $-\mathrm{SE}_{7,2}=36$ percent, $\mathrm{SE}_{7,10}=48$ percent. 
Table 1.--Low-flow characteristics for sites in the upper Wisconsin River basin--Continued

05393630 Little Pine Creek near Tomahawk, Wis.

Location. - - NW $\frac{1}{4} \mathrm{NW}_{\frac{1}{4}} \mathrm{sec} .32$, on common boundary of secs. 31 and $32, \mathrm{~T} .34 \mathrm{~N} ., \mathrm{R} .7$ E., Lincoln County, at culverts on County Trunk V, $6.5 \mathrm{mi}$ southeast of Tomahawk.

Drainage area. $--21.0 \mathrm{mi}^{2}$. Tributary to.--Wisconsin River.

Type of site.--Low-flow partial-record station.

Minimum discharge measured. $-3.61 \mathrm{ft}^{3} / \mathrm{s}$, Aug. 19, 1969 .

Low-flow frequency. - $-Q_{7,2}=4.3 \mathrm{ft}^{3} / \mathrm{s}, Q_{7,10}=3.2 \mathrm{ft}^{3} / \mathrm{s}$.

Basis of estimate.--Graphical regression with Prairie River near Merrill using 15 discharge measurements made during the period 1967-79.

Accuracy. $--\mathrm{SE}_{7,2}=10$ percent, $S E_{7,10}=13$ percent.

05393640 Little Pine Creek near Irma, Wis.

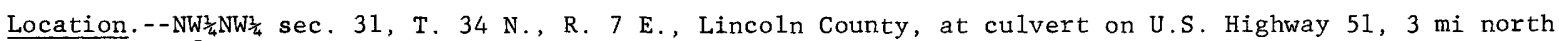
of Irma.

Drainage area. $--22.0 \mathrm{mi}^{2}$. Tributary to. --Wisconsin River.

Type of site.--Miscellaneous site.

Discharge measurement.--Jan. 15, 1976, $5.04 \mathrm{ft}^{3} / \mathrm{s}$.

05393665 Berry Creek tributary near Irma, Wis.

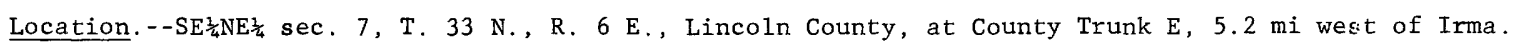

Drainage area. $--3.35 \mathrm{mi}^{2}$.

Tributary to. --Berry Creek.

Type of site.--Miscellaneous site.

Discharge measurement.--Sept. 24, 1979, $0 \mathrm{ft}^{3} / \mathrm{s}$.

Low-flow frequency. $-0_{7,2}=0 \mathrm{ft}^{3} / \mathrm{s}, Q_{7,10}=0 \mathrm{ft}^{3} / \mathrm{s}$.

Basis of estimate.--Observation of dry streambed during a period when other stations in the area had flow greater than $Q_{7,2}$ discharge.

Accuracy. --Not applicable.

05393720 Ripley Creek near Irma, Wis.

Location. --SW $\frac{1}{4} \mathrm{NW}_{\frac{3}{4}} \mathrm{sec} .6$, T. $32 \mathrm{~N}$, , R. 6 E., Lincoln County, at mouth, about 6 mi southwest of Irma.

Drainage area. $--5.36 \mathrm{mi}^{2}$. Tributary to.--Wisconsin River.

Type of site.--Miscellaneous site.

Discharge measurement.--Sept. $24,1979,0.07 \mathrm{ft}^{3} / \mathrm{s}$.

Low-flow frequency. $-Q_{7,2}=0.14 \mathrm{ft}^{3} / \mathrm{s}, Q_{7,10}=0.05 \mathrm{ft}^{3} / \mathrm{s}$.

Basis of estimate. --Used multiple-regression equations 3 and 5 .

Accuracy. $--\mathrm{SE}_{7,2}=36$ percent, $\mathrm{SE}_{7,10}=48$ percent. 
Table 1.--Low-flow characteristics for sites in the upper Wisconsin River basin--Continued

05393850 Center Fork New Wood River near Spirit Falls, Wis.

Location. - $-N_{1} \frac{1}{4} \mathrm{SW}_{\frac{1}{4}} \mathrm{sec} .4$, T. 33 N., R. 4 E., Lincoln County, at tcwn road, 5.4 mi south of Spirit Falls. Drainage area. $--5.43 \mathrm{mi}^{2}$. Tributary to. --Wisconsin River.

Type of site.--Miscellaneous site.

Discharge measurement.--Sept. $24,1979,0.27 \mathrm{ft}^{3} / \mathrm{s}$.

Low-flow frequency. $-Q_{7,2}=0.23 \mathrm{ft}^{3} / \mathrm{s}, Q_{7,10}=0.12 \mathrm{ft}^{3} / \mathrm{s}$.

Basis of estimate.--Used multiple-regression equations 3 and 5 .

Accuracy. $--\mathrm{SE}_{7,2}=36$ percent, $S E_{7,10}=48$ percent.

05393910 New Wood River near Irma, Wis.

Location. - $-\mathrm{SW}_{4} \frac{1}{4} \mathrm{NE} \frac{1}{4}$ sec. 32 , T. $33 \mathrm{~N} .$, R. 5 E., Lincoln County, at bridge on County Trunk E, 11.3 mi southwest of Irma.

Drainage area. $--53.0 \mathrm{mi}^{2}$. Tributary to.--Wisconsin River.

Type of site.--Miscellaneous site.

Discharge measurements.--June $29,1971,10.4 \mathrm{ft}^{3} / \mathrm{s} ;$ Oct. $11,1971,19.9 \mathrm{ft}^{3} / \mathrm{s} ; \mathrm{Sept} .24,1979,4.86 \mathrm{ft}{ }^{3} / \mathrm{s}$. Low-flow frequency. $--Q_{7,2}=3.9 \mathrm{ft}^{3} / \mathrm{s}, Q_{7,10}=2.1 \mathrm{ft}^{3} / \mathrm{s}$.

Basis of estimate.--Graphical regression with Spirit River near Spirit Falls using 3 discharge measurements. Accuracy. $--\mathrm{SE}_{7,2}=28$ percent, $\mathrm{SE}_{7,10}=38$ percent (basin average).

05393916 Averil1 Creek near New Wood, Wis.

Location. --SW $\frac{1}{4} S E \frac{1}{4}$ sec. 21, T. 33 N., R. 5 E., Lincoln County, at County Trunk E, 1.5 mi east of New Wood.

Drainage area. $--10.6 \mathrm{mi}^{2}$. Tributary to.--New Wood River.

Type of site.--Miscellaneous site.

Discharge measurement.--Sept. 24, $1979,0.52 \mathrm{ft}^{3} / \mathrm{s}$.

Low-flow frequency. $-Q_{7,2}=0.39 \mathrm{ft}^{3} / \mathrm{s}, Q_{7,10}=0.18 \mathrm{ft}^{3} / \mathrm{s}$.

Basis of estimate.--Used multiple-regression equations 3 and 5 .

Accuracy. $-\mathrm{SE}_{7,2}=36$ percent, $\mathrm{SE}_{7,10}=48$ percent. 
Table 1.--Low-flow characteristics for sites in the upper wisconsin River basin--Continued

05394000 New Wood River near Merrill, Wis.

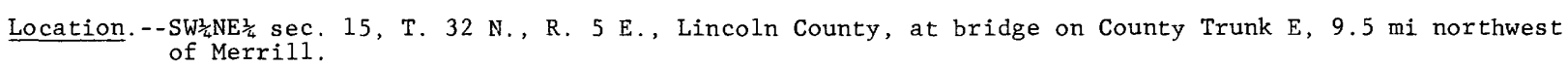

Drainage area. --82.2 $\mathrm{mi}^{2}$. Tributary to.--Wisconsin River.

Type of site.--Gaging station, complete partial-record station.

Period of record.--October 1952 to September 1961. October 1961 to September 1979, complete partial-record station.

Average discharge. --9 years, $72.7 \mathrm{ft}^{3} / \mathrm{s}$.

Extremes.--Maximum discharge, $1,370 \mathrm{ft}^{3} / \mathrm{s}$ July 9, 1959; minimum daily discharge, $1 \mathrm{ft} / \mathrm{s} \mathrm{Jan.} \mathrm{11-Feb:} \mathrm{20,}$ 1959.

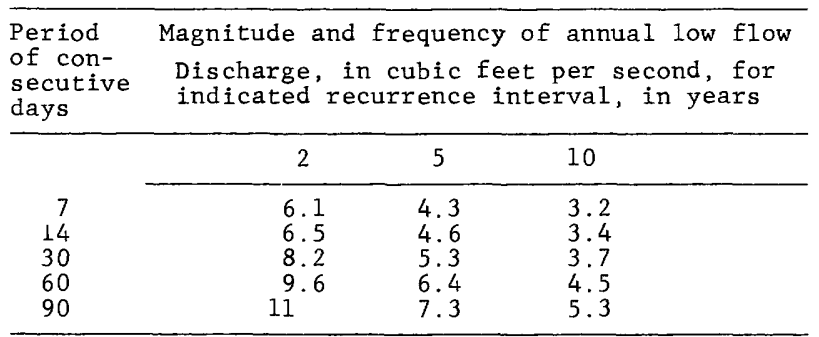

\begin{tabular}{|c|c|c|c|c|c|c|c|}
\hline $\begin{array}{l}\text { Discharg } \\
\text { was. exce }\end{array}$ & $\begin{array}{l}\text { ation } \\
\text { in } c \\
\text { ed fol }\end{array}$ & $\begin{array}{l}\text { tabI } \\
\text { ubic } \\
\text { r ind }\end{array}$ & $\begin{array}{l}\text { of d } \\
\text { eet p } \\
\text { cated }\end{array}$ & $\begin{array}{l}\text { aily } \\
\text { er se } \\
\text { perc }\end{array}$ & $\begin{array}{l}\text { flow } \\
\text { cond, } \\
\text { ent o }\end{array}$ & $\begin{array}{l}\text { whic } \\
\text { f tim }\end{array}$ & \\
\hline Percent & 2 & 5 & 10 & 20 & 30 & 40 & 50 \\
\hline $\mathrm{ft}^{3} / \mathrm{s}$ & 540 & 350 & 210 & 93 & 47 & 28 & 18 \\
\hline Percent & 60 & 70 & 80 & 90 & 95 & 98 & 99.9 \\
\hline $\mathrm{ft}^{3} / \mathrm{s}$ & 13 & 9.4 & 7.7 & 5.8 & 4.2 & 2.8 & 1.0 \\
\hline
\end{tabular}

Accuracy.--SE $7,2=7$ percent, $\mathrm{SE}_{7,10}=35$ percent.

Remarks.--Frequency values based on extending streamflow data to the period 1940-61 using streamflow records from Rib River at Rib Falls (05396000) gaging station. Duration table based on period of recorded discharge at the gaging station 1952-61.

05394002 New Wood River near Merrill, Wis.

Location.-- $-\mathrm{NW}_{\frac{1}{4}} \mathrm{SW}_{\frac{1}{4}} \mathrm{sec} .24$, T. $32 \mathrm{~N}$, R. 5 E., Lincoln County, at bridge on town road, $8.4 \mathrm{mi}$ northwest of Merrill.

Drainage area. $--85.9 \mathrm{mi}^{2}$.

Tributary to. --Wisconsin River.

Type of site.--Miscellaneous site.

Discharge measurement.--Jan. $1,1976,13.4 \mathrm{ft}^{3} / \mathrm{s}$.

05394004 Joe Snow Creek near Merril1, Wis.

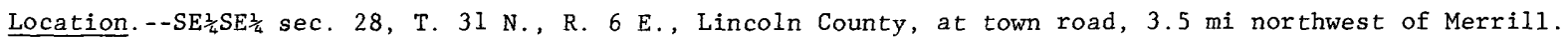

Drainage area. $--9.08 \mathrm{mi}^{2}$.

Tributary to.--Wisconsin River.

Type of site.--Miscellaneous site.

Discharge measurement.--Sept. 24, 1979, $0.39 \mathrm{ft}^{3} / \mathrm{s}$.

Low-flow frequency. $-Q_{7,2}=0.61 \mathrm{ft}^{3} / \mathrm{s}, Q_{7,10}=0.28 \mathrm{ft}^{3} / \mathrm{s}$.

Basis of estimate. --Used multiple-regression equations 3 and 5 .

Accuracy.-- $-\mathrm{SE}_{7,2}=36$ percent, $\mathrm{SE}_{7,10}=48$ percent. 
Table 1.--Low-flow characteristics for sites in the upper Wisconsin River basin--Continued

05394110 Middle Fork Copper River near Hamburg, Wis.

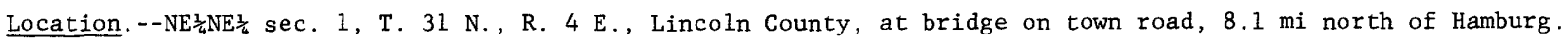
Drainage area. $--16.4 \mathrm{mi}^{2}$. Tributery to.--Copper River.

Type of site. --Miscellaneous site.

Discharge measurement.--0ct. $11,1971,8.76 \mathrm{ft}^{3} / \mathrm{s}$.

05394130 South Fork Copper River near Hamburg, Wis.

Location.-- $\mathrm{NW}_{\frac{1}{4}} \mathrm{SE}_{\frac{1}{4}} \mathrm{sec} .8$, T. 31 N., R. 5 E., Lincoln County, at bridge on County Trunk M, $6.5 \mathrm{mi}$ north of Hamburg.

Drainage area. $--15.8 \mathrm{mi}^{2}$.

Tributary to.--Middle Fork Copper River.

Type of site.--Miscellaneous site.

Discharge measurements. --0ct. 11, 1971, $6.54 \mathrm{ft}^{3} / \mathrm{s} ;$ Sept. 24,1979 , no flow.

05394160 Copper River near Hamburg, Wis .

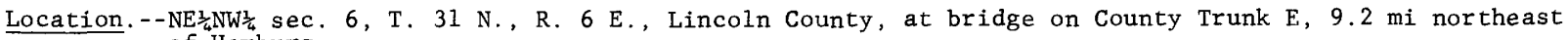
of Hamburg.

Drainage area. $--94.4 \mathrm{mi}^{2}$.

Tributary to. --Wisconsin River.

Type of site.--Miscellaneous site.

Discharge measurements.--June 29, 1971, $14.2 \mathrm{ft}^{3} / \mathrm{s} ;$ Oct. 11, 1971, $42.9 \mathrm{ft} / \mathrm{s} ;$ Sept. 24, $1979,7.92 \mathrm{ft} / \mathrm{s}$. Low-flow frequency. $-Q_{7,2}=5.4 \mathrm{ft}^{3} / \mathrm{s}, 0_{7,10}=2.5 \mathrm{ft}^{3} / \mathrm{s}$.

Basis of estimate.--Graphical regression with Spirit River at Spirit Falls using 3 discharge measurements. Accuracy. $-\mathrm{SE}_{7,2}=28$ percent, $\mathrm{SE}_{7,10}=38$ percent (basin average).

05394200 Devil Creek near Merrill, Wis.

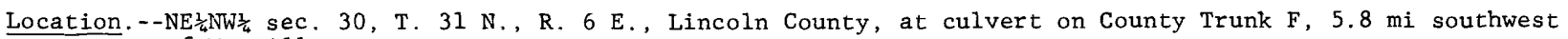
of Merrill.

Drainage area. $--9.58 \mathrm{mi}^{2}$. Tributary to.--Wisconsin River.

Type of site.--Low-flow partial-record station.

Minimum discharge measured. $--0.50 \mathrm{ft}^{3} / \mathrm{s}$, Aug. $22,1962$.

Low-flow frequency. $-Q_{7,2}=0.56 \mathrm{ft}^{3} / \mathrm{s}, Q_{7,10}=0.35 \mathrm{ft}^{3} / \mathrm{s}$.

Basis of estimate. - Graphical regression with Spirit River at Spirit Falls using 22 discharge measurements made during the period 1962-79.

Accuracy. $-\mathrm{SE}_{7,2}=11$ percent, $\mathrm{SE}_{7,10}=17$ percent.

05394205 Devil Creek near Merrill, Wis.

Location. - - $\mathrm{NE}_{\frac{1}{4}} \mathrm{NE}_{\frac{1}{4}} \mathrm{sec} .20$, T. $31 \mathrm{~N}$, , R. 6 E., Lincoln County, at bridge on town road, $3.1 \mathrm{mi}$ southwest of Merrill.

Drainage area. $--21.5 \mathrm{mi}^{2}$. Tributary to.--Wisconsin River.

Type of site.--Miscellaneous site.

Discharge measurements.--Oct. $11,1971,3.56 \mathrm{ft}^{3} / \mathrm{s} ;$ Sept. $24,1979,2.78 \mathrm{ft}^{3} / \mathrm{s}$.

Low-flow frequency. $-Q_{7,2}=2.0 \mathrm{ft}^{3} / \mathrm{s}, Q_{7,10}=1.2 \mathrm{ft}^{3} / \mathrm{s}$.

Basis of estimate.--Used multiple-regression equations 3 and 5 .

Accuracy. $--\mathrm{SE}_{7,2}=36$ percent, $\mathrm{SE}_{7,10}=48$ percent. 
05394207 Devil Creek at Merrill, Wis.

Location. - - $-W_{\frac{1}{4}} \mathrm{NE}^{\frac{1}{4}} \mathrm{sec} .15$, T. $31 \mathrm{~N} .$, R. 6 E., Lincoln County, at Foster Street bridge, at Merrill.

Drainage area. --27 . I $\mathrm{mi}^{2}$.

Tributary to.--Wisconsin River.

Type of site.--Miscellaneous site.

Discharge measurement.--Jan. $15,1976,3.27 \mathrm{ft}^{3} / \mathrm{s}$.

05394250 Prairie River at Parrish, Wis.

Location. --SW $\frac{1}{4} \mathrm{NW}^{\frac{1}{4}} \mathrm{sec} .20$, T. $34 \mathrm{~N}$, R. 9 E., Langlade County, at bridge on County Trunk H, $0.2 \mathrm{mi}$ south of Parrish.

Drainage area. $--37.3 \mathrm{mi}^{2}$.

Tributary to.--Wisconsin River.

Type of site.--Miscellaneous site.

Discharge measurements.--0ct. $12,1971,32.4 \mathrm{ft}^{3} / \mathrm{s} ; \operatorname{Sept} .24,1979,17.8 \mathrm{ft}^{3} / \mathrm{s}$.

Low-flow frequency. $-Q_{7,2}=11 \mathrm{ft}^{3} / \mathrm{s}, Q_{7,10}=8.2 \mathrm{ft}^{3} / \mathrm{s}$.

Basis of estimate.--Used multiple-regression equations 3 and 5 .

Accuracy. $--\mathrm{SE}_{7,2}=36$ percent, $\mathrm{SE}_{7,10}=48$ percent.

05394310 Prairie River near Gleason, Wis.

Location.- - NW $\frac{1}{4} \mathrm{NW}_{\frac{1}{4}} \mathrm{sec} .23$, T. $33 \mathrm{~N} .$, R. $8 \mathrm{E}$., Lincoln County, at bridge on State Highway $17,2.4 \mathrm{mi}$ north of Gleason.

Drainage area. $--61.4 \mathrm{mi}^{2}$.

Tributary to. --Wisconsin River.

Type of site.--Miscellaneous site.

Discharge measurements.--Oct. 12, $1971,53.0 \mathrm{ft}^{3} / \mathrm{s} ;$ Sept. $24,1979,43.3 \mathrm{ft}^{3} / \mathrm{s}$.

Low-flow frequency. $-Q_{7,2}=25 \mathrm{ft}^{3} / \mathrm{s}, Q_{7,10}=20 \mathrm{ft} / \mathrm{s}$.

Basis of estimate.--Used multiple-regression equations 3 and 5 .

Accuracy.- $-\mathrm{SE}_{7,2}=36$ percent, $\mathrm{SE}_{7,10}=48$ percent.

05394380 North Branch Prairie River near Gleason, Wis.

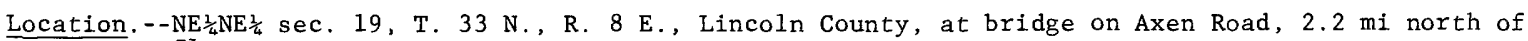
Gleason.

Drainage area. $--34.8 \mathrm{mi}^{2}$. Tributary to.--Prairie River.

Type of site.--Miscellaneous site.

Minimum discharge measured.--10.8 $\mathrm{ft}^{3} / \mathrm{s}$, Sept. $24,1979$.

Low-flow frequency. $-Q_{7,2}=12 \mathrm{ft}^{3} / \mathrm{s}, Q_{7,10}=9.4 \mathrm{ft}^{3} / \mathrm{s}$.

Basis of estimate.--Graphical regression with Prairie River near Merrill using 9 discharge measurements made during the period 1971-79.

Accuracy. $--\mathrm{SE}_{7,2}=26$ percent, $\mathrm{SE}_{7,10}=26$ percent. 
Table 1.--Low-flow characteristics for sites in the upper Wisconsin River basin--Continued

05394420 Silver Creek near Parrish, Wis.

Location. - -SW $\frac{1}{4} \mathrm{NW}^{\frac{1}{4}} \mathrm{sec} .18$, T. 33 N., R. 8 E., Langlade County, on town road, about $5.0 \mathrm{mi}$ south of Parrish. Drainage area. $--4.08 \mathrm{mi}^{2}$. Tributary to.--Big Hay Meadow Creek.

Type of site.--Miscellaneous site.

Discharge measurement.--Sept. 24, $1979,0.83 \mathrm{ft}^{3} / \mathrm{s}$.

Low-flow frequency. $-Q_{7,2}=0.74 \mathrm{ft}^{3} / \mathrm{s}, Q_{7,10}=0.40 \mathrm{ft}^{3} / \mathrm{s}$.

Basis of estimate.--Used multiple-regression equations 3 and 5 .

Accuracy. $--\mathrm{SE}_{7,2}=36$ percent, $\mathrm{SE}_{7,10}=48$ percent.

05394450 Big Hay Meadow Creek near Gleason, Wis.

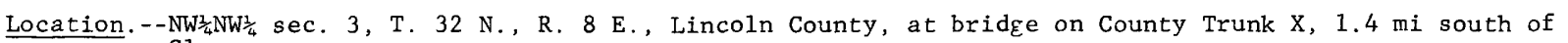
Gleason.

Drainage area. $--32.3 \mathrm{mi}^{2}$. Tributary to. --Prairie River.

Type of site.--Miscellaneous site.

Discharge measurements.--0ct. 12, 1971, $14.0 \mathrm{ft}^{3} / \mathrm{s} ;$ Sept. $24,1979,5.53 \mathrm{ft}^{3} / \mathrm{s}$.

Low-flow frequency. $-Q_{7,2}=5.0 \mathrm{ft}^{3} / \mathrm{s}, Q_{7,10}=3.0 \mathrm{ft}^{3} / \mathrm{s}$.

Basis of estimate.--Used multiple-regression equations 3 and 5 .

Accuracy. $--\mathrm{SE}_{7,2}=36$ percent, $\mathrm{SE}_{7,10}=48$ percent.

05394500 Prairie River near Merril1, Wis .

Location. - - SW $\frac{2}{4}$ SW $\frac{1}{4}$ sec. 20, T. $32 \mathrm{~N}$, R. 7 E., Lincoln county, near center of span on downstream side of County Trunk C bridge, $1.5 \mathrm{mi}$ upstream from Meadow Creek, $4.5 \mathrm{mi}$ northeast of Meril1, $8.0 \mathrm{mi}$ upstream from mouth.

Drainage area. - $-184 \mathrm{mi}^{2}$. Tributary to. - -Wisconsin River.

Type of site.--Gaging station.

Period of record.--January 1914 to September 1931; August 1939 to September 1977.

Average discharge. -55 years, $180 \mathrm{ft}^{3} / \mathrm{s}$.

Extremes.--Maximum discharge, $5,800 \mathrm{ft}^{3} / \mathrm{s}$ Aug. 31, 1941; mirimum discharge, $34 \mathrm{ft}^{3} / \mathrm{s}$ 0ct. $26,1947$.

\begin{tabular}{lcccccc}
\hline $\begin{array}{l}\text { Period } \\
\text { of con- } \\
\text { secutive } \\
\text { days }\end{array}$ & $\begin{array}{l}\text { Magnitude and frequency of annual low flow } \\
\text { Discharge, in cubic feet per second, for } \\
\text { indicated recurrence interval, in years } \\
\text { ind }\end{array}$ \\
\hline & 2 & 5 & 10 & 20 & 50 & 100 \\
\hline 7 & 71 & 64 & 60 & 58 & 55 & 53 \\
14 & 73 & 66 & 63 & 61 & 58 & 57 \\
30 & 76 & 68 & 65 & 63 & 61 & 60 \\
60 & 80 & 71 & 68 & 66 & 64 & 62 \\
90 & 85 & 75 & 70 & 67 & 65 & 63 \\
\hline
\end{tabular}

Duration table of daily flow

Discharge, in cubic feet per second, which was exceeded for indicated percent of time

\begin{tabular}{rrrrrrrr}
\hline $\begin{array}{c}\text { Percent } \\
\mathrm{ft}\end{array}{ }^{3} / \mathrm{s}$ & 820 & 5 & 10 & 20 & 30 & 40 & 50 \\
\hline Percent & 60 & 70 & 80 & 90 & 95 & 98 & 99.9 \\
$\mathrm{ft} \mathrm{t}^{3} / \mathrm{s}$ & 100 & 91 & 83 & 75 & 70 & 65 & 56 \\
\hline
\end{tabular}

Accuracy. $--\mathrm{SE}_{7,2}=2$ percent, $\mathrm{SE}_{7,10}=2$ percent. 
05394750 Meadow Creek near Merrill, Wis.

Location. - - SW $\frac{1}{4} \mathrm{SW}_{\frac{1}{4}} \mathrm{sec} .19, \mathrm{~T} .32 \mathrm{~N} ., \mathrm{R} .7 \mathrm{E}$, Lincoln County, at bridge on town road, $3.8 \mathrm{mi}$ north of Merrill. Drainage area. $--23.8 \mathrm{mi}^{2}$. Tributary to.--Prairie River.

Type of site.--Miscellaneous site.

Discharge measurements. --June 29, 1971, $4.75 \mathrm{ft}^{3} / \mathrm{s} ;$ Oct. $11,1971,5.26 \mathrm{ft} / \mathrm{s} ;$ Sept. $24,1979,3.60 \mathrm{ft}^{3} / \mathrm{s}$. Low-flow frequency. $-Q_{7,2}=3.1 \mathrm{ft}^{3} / \mathrm{s}, Q_{7,10}=2.7 \mathrm{ft} / \mathrm{s}$.

Basis of estimate.--Graphical regression with Prairie River near Merrill using 3 discharge measurements.

Accuracy. $--\mathrm{SE}_{7,2}=28$ percent, $\mathrm{SE}_{7,10}=38$ percent (basin average).

05394768 Barnes Creek near Merril1, Wis.

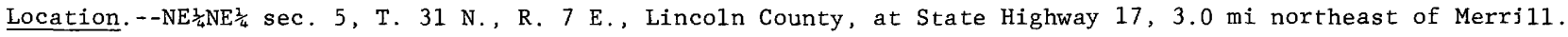
Drainage area. $--9.90 \mathrm{mi}^{2}$. Tributary to. --Prairie River.

Type of site.--Miscellaneous site.

Discharge measurement.--Sept. 24, 1979, $1.29 \mathrm{ft}^{3} / \mathrm{s}$.

Low-flow frequency. $-Q_{7,2}=0.65 \mathrm{ft}^{3} / \mathrm{s}, 0.7,10=0.34 \mathrm{ft}^{3} / \mathrm{s}$.

Basis of estimate.--Used multiple-regression equations 3 and 5 .

Accuracy.-- $\mathrm{SE}_{7,2}=36$ percent, $\mathrm{SE}_{7,10}=48$ percent.

05394797 Prairie River at Merril1, Wis.

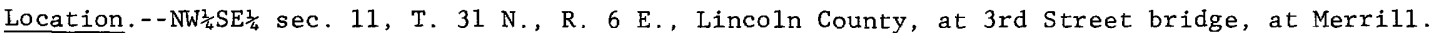

Drainage area. $--231 \mathrm{mi}^{2}$.

Tributary to. - -Wisconsin River.

Type of site.--Miscellaneous site.

Discharge measurement.--Jan. 15, 1976, $118 \mathrm{ft}^{3} / \mathrm{s}$.

05395000 Wisconsin River at Merril1, Wis.

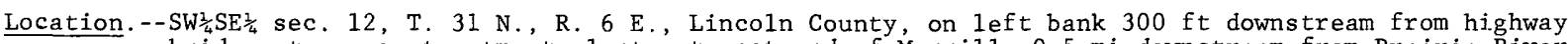
bridge at sewage-treatment plant, at east end of Merrill, 0.5 mi downstream from Prairie River.

Drainage area. $--2,760 \mathrm{mi}^{2}$. Tributary to.--Mississippi River.

Type of site.--Gaging station.

Period of record.--November 1902 to September 1977.

Average discharge. -74 years, $2,665 \mathrm{ft}^{3} / \mathrm{s}$.

Extremes.--Maximum discharge, $49,400 \mathrm{ft}^{3} / \mathrm{s}$ Aug. 31, 1941; minimum discharge, about $90 \mathrm{ft}^{3} / \mathrm{s} \mathrm{Sept.} 26,1908$.

\begin{tabular}{lrrrrrr}
\hline $\begin{array}{l}\text { Period } \\
\text { of con- } \\
\text { secutive } \\
\text { days }\end{array}$ & $\begin{array}{l}\text { Magnitude and frequency of annual low flow } \\
\text { Discharge, in cubic feet per second, for } \\
\text { indicated recurrence }\end{array}$ \\
\hline & 2 & 5 & 10 & 20 & 50 & 100 \\
\hline 7 & 1,370 & 977 & 757 & 586 & 419 & 324 \\
14 & 1,370 & 1,030 & 864 & 735 & 603 & 523 \\
30 & 1,440 & 1,130 & 980 & 867 & 749 & 677 \\
60 & 1,530 & 1,200 & 1,040 & 924 & 803 & 729 \\
90 & 1,600 & 1,250 & 1,090 & 960 & 831 & 752
\end{tabular}

\begin{tabular}{|c|c|c|c|c|c|c|}
\hline $\begin{array}{l}\text { Dischar } \\
\text { was exc }\end{array}$ & $\begin{array}{l}\text { uration } \\
\text { e, in c } \\
\text { eded fo }\end{array}$ & $\begin{array}{l}\text { table } \\
\text { ubic f } \\
r \text { indic }\end{array}$ & $\begin{array}{l}\text { of dai } \\
\text { et per } \\
\text { ated p }\end{array}$ & $\begin{array}{l}\text { y flow } \\
\text { second, } \\
\text { rcent }\end{array}$ & $\begin{array}{l}\text { which } \\
\text { f time }\end{array}$ & \\
\hline Percent & 2 & 5 & 10 & 20 & 30 & 40 \\
\hline $\mathrm{ft}^{3} / \mathrm{s}$ & 9,100 & 6,700 & 4,900 & 3,250 & 2,650 & 2,300 \\
\hline Percent. & 50 & 60 & 70 & 80 & 90 & 95 \\
\hline $\mathrm{ft}^{3} / \mathrm{s}$ & 2,100 & 1,900 & 1,700 & 1,500 & 1,200 & 1,000 \\
\hline Percent & 98 & 99.9 & & & & \\
\hline $\mathrm{ft}^{3} / \mathrm{s}$ & 890 & 460 & & & & \\
\hline
\end{tabular}

Accuracy. $-\mathrm{SE}_{7,2}=3$ percent, $\mathrm{SE}_{7,10}=11$ percent.

Remarks.--Flow regulated by 20 reservoirs and 9 powerplants upstream from station. 
Table 2.--Basin characteristics for low-flow partial-record stations and selected gaging stations in the upper Wisconsin River basin

\begin{tabular}{|c|c|c|c|c|c|c|}
\hline $\begin{array}{l}\text { Station } \\
\text { number }\end{array}$ & Station name & $\begin{array}{c}\text { Drainage } \\
\text { area } \\
\left(\mathrm{mi}^{2}\right) \\
\mathrm{A}\end{array}$ & $\begin{array}{c}\text { Main-channel } \\
\text { slope } \\
\text { (ft/mi) } \\
\text { s }\end{array}$ & $\begin{array}{c}\text { Main-channe1 } \\
\text { length } \\
\text { (mi) } \\
\text { L }\end{array}$ & $\begin{array}{c}\text { Basin } \\
\text { storage } \\
\text { (percent) } \\
\text { Bs }\end{array}$ & $\begin{array}{c}\begin{array}{c}\text { Forest } \\
\text { cover } \\
\text { (percent) }\end{array} \\
F\end{array}$ \\
\hline 05390140 & Muskrat Creek at Conover & 10.2 & 7.67 & 10.5 & 12.3 & 85.8 \\
\hline 05390450 & Deerskin River near Eagle River & 32.4 & 11.0 & 11.9 & 20.4 & 63.8 \\
\hline 05391200 & Monico Creek near Monico & 20.8 & 6.02 & 13.5 & 39.8 & 84.0 \\
\hline 05391250 & Gudegast Creek near Rhinelander & 12.4 & 3.8 & 8.06 & 29.4 & 73.9 \\
\hline 05391900 & Noisy Creek near Rhinelander & 35.6 & 8.07 & 13.0 & 28.4 & 88.6 \\
\hline 05392150 & Mishonagon Creek near Woodruff & 17.6 & 6.77 & 8.00 & 15.6 & 84.0 \\
\hline 05392290 & Willow River near Hazelhurst & 9.92 & 9.7 & 9.2 & 39.3 & 95.9 \\
\hline 05392320 & Rocky Run near Goodnow & 23.2 & 3.09 & 10.4 & 25.7 & 76.3 \\
\hline 05392350 & Bearskin Creek near Harshaw & 31.1 & 6.48 & 14.3 & 29.7 & 70.3 \\
\hline 05392450 & Little Rice River near Bradley & 21.4 & 3.03 & 17.8 & 39.1 & 90.5 \\
\hline 05393200 & Somo River near Tripoli & 43.5 & 12.4 & 14.1 & 27.8 & 81.9 \\
\hline 05393500 & Spirit River at Spirit Falls & 81.6 & 12.5 & 18.7 & 18.2 & 52.5 \\
\hline 05393630 & $\begin{array}{l}\text { Little Pine Creek near } \\
\text { Tomahawk }\end{array}$ & 21.0 & 25.7 & 10.5 & 13.9 & 77.3 \\
\hline 05394000 & New Wood River near Merrill & 82.2 & 14.7 & 21.5 & 15.5 & 85.2 \\
\hline 05394200 & Devil Creek near Merrill & 9.58 & 10.5 & 6.6 & 3.48 & 27.4 \\
\hline 05394500 & Prairie River near Merrill & 184 & 10.4 & 38.2 & 24.2 & 75.6 \\
\hline
\end{tabular}


Table 2.--Basin characteristics for low-flow partial-record stations and. selected gaging station in the upper Wisconsin River basin

\begin{tabular}{|c|c|c|c|c|c|c|}
\hline $\begin{array}{c}\text { Mean annual } \\
\text { precipitation } \\
\text { (in.) } \\
\text { P }\end{array}$ & $\begin{array}{l}\text { Soil infil- } \\
\text { tration } \\
\text { rate } \\
\text { (in/hr) }\end{array}$ & $\begin{array}{c}\text { Mean } \\
\text { annual } \\
\text { snowfall } \\
\text { (in.) }\end{array}$ & $\begin{array}{c}\text { Base-flow } \\
\text { index } \\
\left(\mathrm{ft} \mathrm{t}^{3} / \mathrm{s}\right) / \mathrm{mi}^{2} \\
\text { Bf }\end{array}$ & $\begin{array}{c}\text { Hydraulic } \\
\text { conductivity } \\
\text { (gal/d) } / f t^{2} \\
\text { K }\end{array}$ & $\begin{array}{c}\text { Drift } \\
\text { thickness } \\
\text { (ft) } \\
\text { H }\end{array}$ & $\begin{array}{c}\text { Transmissivity } \\
(\mathrm{ga} 1 / \mathrm{d}) / \mathrm{ft} \\
\mathrm{T}\end{array}$ \\
\hline & & & & & & \\
\hline 31.4 & 5.12 & 67 & 0.324 & 1,300 & 125 & 162,000 \\
\hline 31.1 & 2.45 & 55 & .523 & 1,180 & 125 & 148,000 \\
\hline 30.4 & 1.28 & 55 & .009 & 10 & 25 & 250 \\
\hline 30.6 & 3.75 & 55 & .062 & 2,500 & 75 & 188,000 \\
\hline 30.7 & 1.61 & 52 & .172 & 383 & 126 & 48,300 \\
\hline 32.0 & 7.25 & 60 & .975 & 2,500 & 172 & 430,000 \\
\hline 32.5 & 4.50 & 57 & .412 & 981 & 25 & 24,500 \\
\hline 31.0 & 7.50 & 54 & .820 & 2,420 & 125 & 302,000 \\
\hline 31.0 & 6.22 & 48 & .806 & 2,270 & 56 & 127,000 \\
\hline 31.6 & 5.37 & 54 & .084 & 2,370 & 118 & 280,000 \\
\hline 32.8 & .43 & 52 & .085 & 10 & 125 & 1,250 \\
\hline 33.0 & .83 & 46 & .083 & 26 & 137 & 3,560 \\
\hline 30.9 & 3.99 & 48 & .226 & 1,350 & 105 & 142,000 \\
\hline 32.5 & .72 & 48 & .068 & 252 & 99 & 24,900 \\
\hline 32.5 & .50 & 50 & .091 & 10 & 32 & 320 \\
\hline 30.8 & 1.54 & 51 & .408 & 1,270 & 115 & 146,000 \\
\hline
\end{tabular}




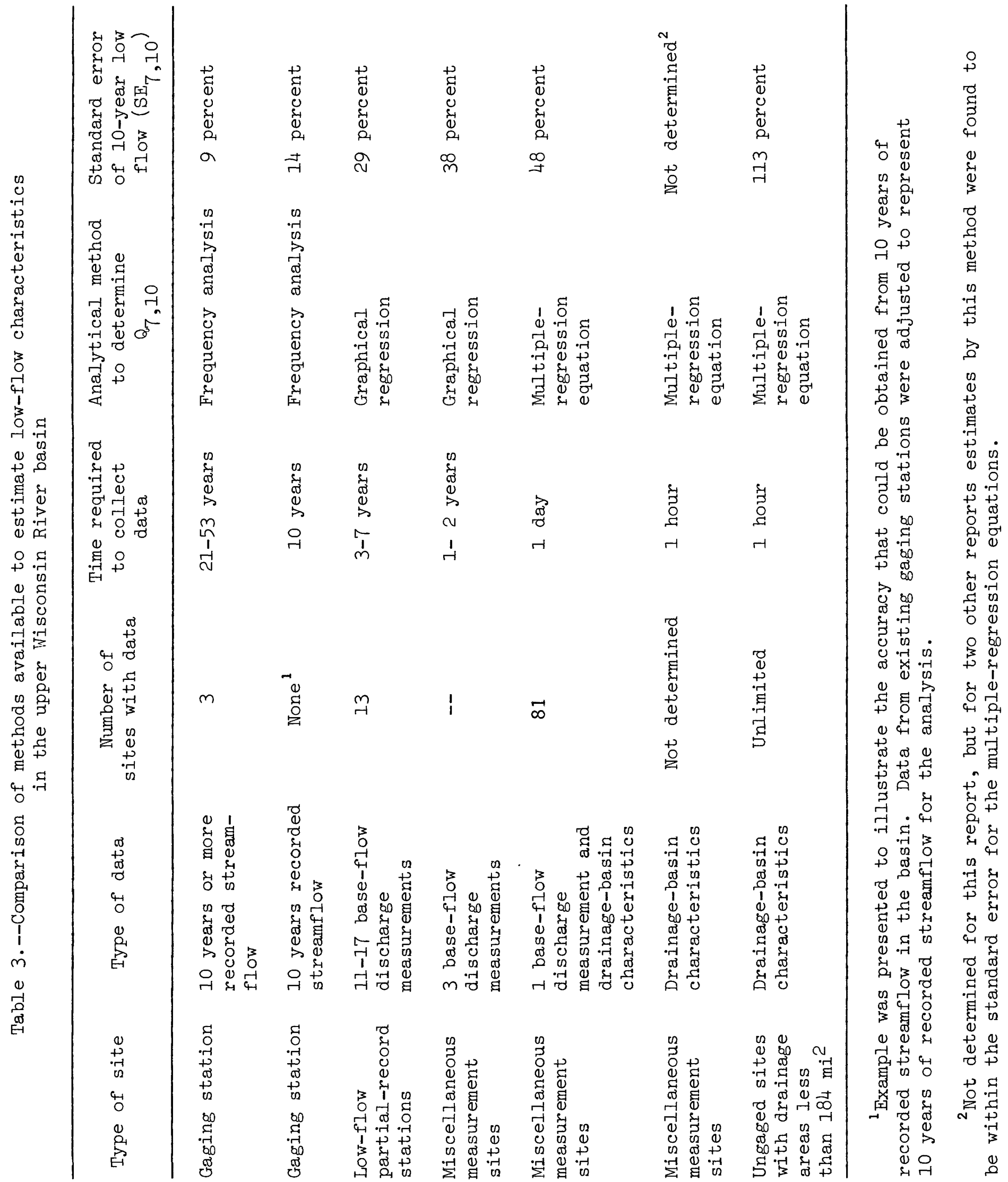

